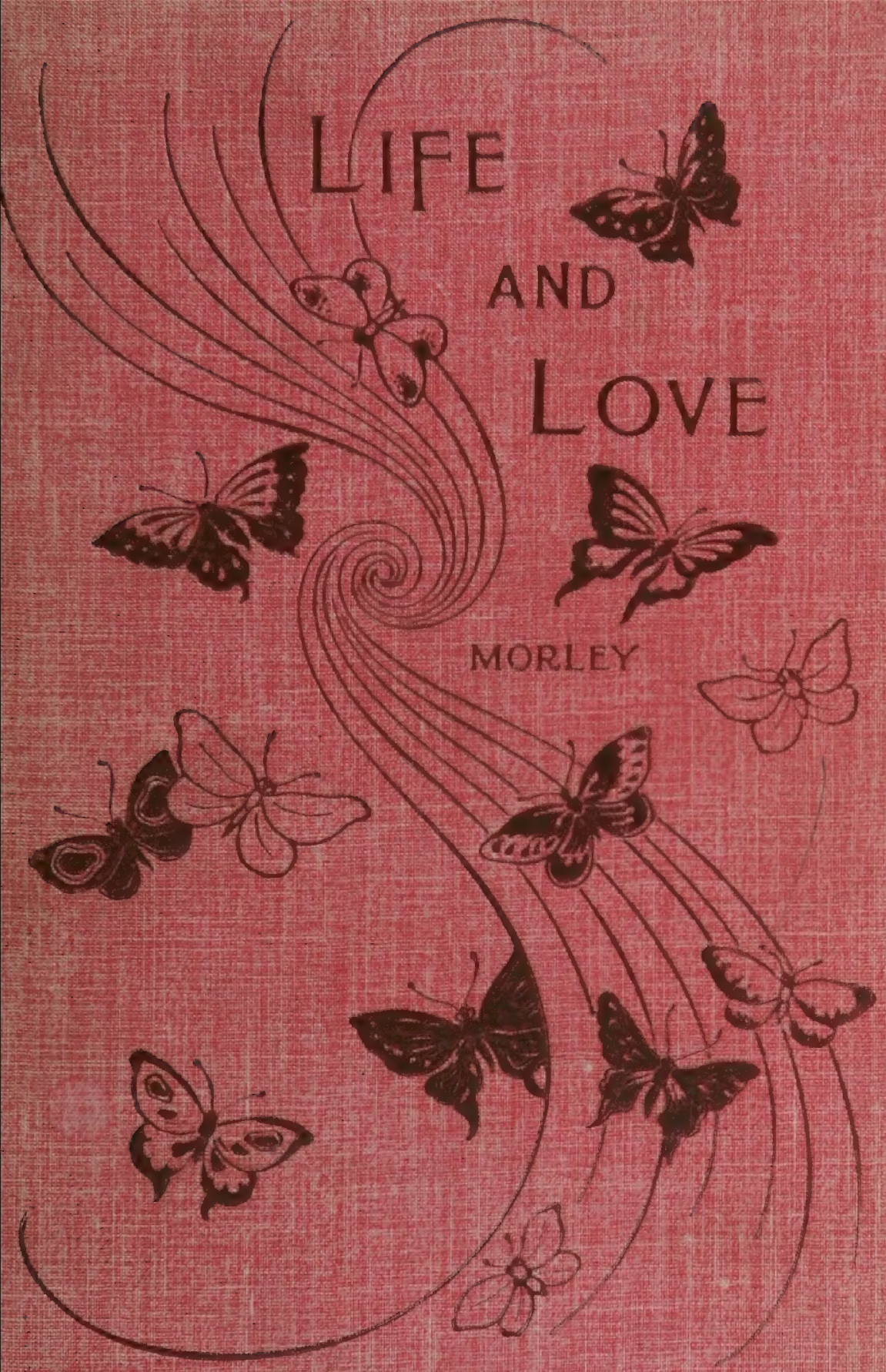




\title{
Cornell Unípersite
}

\section{Librare}

\author{
OF THE
}

Hew Dork state College of Figriculture Turean of Natise study

Ag 2336

$28 / 6 \mid 10$ 


\section{Cornell University Library}

QH 81.M86

Life and love,

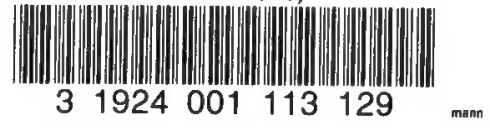




\section{Cornell University Library}

The original of this book is in the Cornell University Library.

There are no known copyright restrictions in the United States on the use of the text. 


LIFE AND LOVE 


\section{Bũ 1 fliss ytorley.}

A SONG OF LIFE. $12 \mathrm{mo}$. $\$ 1.25$.

LIFE AND LOVE. $12 \mathrm{mo}$. \$1.25.

The Bee People. 12mo. \$1.25.

A. C. MCCLURG AND CO.

Chicago. 


\section{LIFE AND LOV.E}

BY

\section{MARGARET WARNER MORLEY \\ AUTHOR OF "A SONG OF LIFE," ETC.}

Iflustrated bu the Author

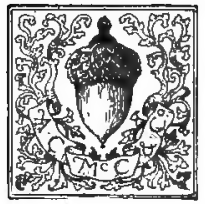

C H I C A G O

A. C. MCCLURG AND COMPANY

1899 


\section{COPYRIGHT,}

By A. C. McClung \& Co.

A.D. 1895 . 


\section{CONTENTS.}

$\begin{array}{ll}\text { CHAPTER } & \text { PAGE }\end{array}$

I. INTRODUCTION . . . . . . . . . . . . 7

II. First Parents. . . . . . . . . . . . . II

III. SPIRogrra . . . . . . . . . . . . . . 2 I

IV. The Division of Labor . . . . . . . 26

V. Fish Life . . . . . . . . . . . . $3^{8}$

VI. Crustaceans . . . . . . . . . . . . 47

VII. Metamorphosis of Insects. . . . . . . 54

VIII. Reproduction of Insects . . . . . . . . 63

IX. Flowers and Insects : . . . . . . • . 74

X. Plant Life. . . . . . . . . . . . . 88

XI. BIRD IIIFE . . . . . . . . . . . . 98

Xil. Skin Changes . . . . . . . . . . . io6

XIII. Pertodic ACrivity . . . . . . . . . . II6

XIV. The Mammal. . . . . . . . . . I 24

XV. Variability and Inheritance . . . . 136

XVI. Nutrition and REproduction . . . . I43

XVII. Value of Sexual Reproduction . • • • I 53

XVIII. INDIVIDUALITY . . . . . . . . . . . . I60

XIX. Male and Femal.e. . . . . . . . . . I69

XX. Maturity . . . . . . . . . . . . I78

XXI. Human Life . . . . . . . . . . . . . I89

XXII. Man and the Community . . . . . . 198 XXIII Conclusion... . . . . . . . . . 210 



\section{LIFE AND LOVE.}

\section{I.}

INTRODUCTION.

$\mathrm{I}^{\mathrm{N}}$ all ages of the world, among all peoples, the 1 same question, What is life? has been asked, and has never been answered. To-day we are all eagerly asking it. The great men of science accumulate observations about it, but cannot satisfy us. The poet and the philosopher give us the inspiring and consoling, reply that life, someway, is a part of a Divine Life, manifested. But aside from this thought of the poet, we seem to ourselves to come nearest to some understanding of this mystery when we speak the great companion, word "love," - love, the great continuer of life.

It is in itself a mystery nearly as deep as the mystery of life; its high office is that of drawing together, uniting, perfecting, renewing, - the same power working in the single cell, in the complex structure, and - with what a sublime difference in the human being! 
Human love has been the poetic theme of man from the beginning, the one imperishable theme, the theme appealing most powerfully to the imagination and the heart, promising solution to the hard problems of life, and offering consolation and satisfaction to the yearning soul.

Man is ever looking towards the ideal love to lift and save him; the universal reproductive instinct seems to hin to promise continuance and progress to his spirit as well as to his body.

The primitive form of love, the root from which all love has grown, is the reproductive instinct, the instinct that attracts one sex to the other for the purpose of re-creation.

From this germinal love has grown and blossomed that altruistic love which finally distinguishes man from all other earthly life.

The understanding of human love in all its manifestations, physical and spiritual, is necessary to the well-being of the world.

To understand the universality of the reproductive instinct in all the life of the earth, to understand the meaning and power of the sex-instinct, the grandeur of the sex-idea, and the immense beauty of its manifestations, - is necessary to the understanding of human love, and is the immediate duty of our day.

To understand love in all its aspects, to know it in its beauty, its greatness, and its power, and to free it from all ideas of grossness and evil is 


\section{Introduction.}

the instant duty, as it is the best hope of our race.

Consciously to relate love to the great cosmic forces which we see everywhere operating throughout nature, to withdraw it from the realm of shame and superstition it has so long inhabited, to depose the sensual usurper which has been worshipped in the name of love, and to set Love herself upon the throne, fair, luminous, and pure to save and bless, is the effort of multitudes of minds in the present day.

The following pages are not an attempt to add to the wealth of discovery made by science in the present remarkable era; they are intended solely to place within reach of the ordinary reader truths as a rule so encased in technical phrascology that many people, desirous of knowing the mysteries of the living being, so far as these have been revealed by modern research, cannot get at the facts because of lack of time or inclination to become familiar with the technical forms of expression.

The last fifty years have been unexampled in the world's history in the discovery of facts concerning the physical life. These facts concern every one, and besides being of unparalleled interest in themselves, they have a direct bearing upon the guidance of individual life.

Much in the life of the individual that scems isolated, chaotic, and incomprehensible, becomes 
intelligible when viewed in the light of the facts of universal life.

In regard to sex-life there often reigns the wildest confusion of thought, and it is in the hope of helping to place in an orderly, harmonious, and worthy position the most important fact of our physical existence that this little book is offered to the public. 


\section{II.}

FIRST PARENTS.

THE living being is constantly changing; 1 unlike the crystal, which, once formed, remains fixed, it continues to change as long as it continues to exist. It has the motion of life, is always wasting, always needing renewal; and this whether it be of microscopic or colossal size. For its renewal it constantly demands food, and whether it be animal or plant, lives only upon condition that it have its proper supply.

The first, the strongest, the most urgent cry of life is the cry for food.

The second great necessity of life is reproduction. Be it never so well nourished and carefully
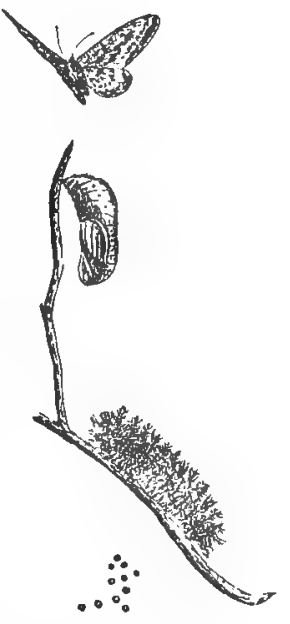
guarded, the individual must sooner or later wane; it loses its initial vitality, and, making a supreme effort towards continued existence, provides for 
future generations. Otherwise its race would become extinct.

Just as food is the first great need of the individual, so is reproduction the first great need of the race. By this mysterious power the places of those who die are filled by others, and the cycle of life is eternally renewed.

From earliest ages to the present day, the mystery of reproduction has held an all-important place in the mind and heart of man. Among the ancients it has been the subject of most sublime religious expressions, and rightly understood, is one of the most beautiful, most wonderful, most sacred of truths.

This renewal, this creation of new beings out of the elements of those that exist, is intimately connected with the mystery of life itself.

Iirom the lowest to the highest, all forms of life possess the power of reproduction.

And what is this mysterious power which awed and puzzled the ancient world as it awes and puzzles us of to-day?

It is the gift of life which the parent makes to the child, the division of the parent, which, no longer able to continue its solitary existence, at a given right time shares its life with another, that other its offspring.

Life in its beginnings is in outer appearance all alike and seems very simple. Some forms of life are content to abide always in the beginning; 
other forms mount to higher and more complex existence; but all start alike as a single cell of something we call protoplasm.

Protoplasm is a marvellous thing - is in fact the marvellous thing.

In appearance it is a colorless, transparent, jellylike substance, concerning whose existence and importance the world was long in ignorance, because of its insignificant appearance, and because of the way in which it was surrounded and concealed by all sorts of substances which it had itself created. But now it is known that protoplasm is not only a living substance, but that it is the only living substance. Every animal and plant owes its existence to the protoplasm it contains.

This is incomprehensible until one understands something of the structure of living things, - and not until the microscope had been invented and had lent its aid to the eye of man to see objects otherwise invisible to him, did he suspect the truth concerning the protoplasm.

Now one can place bencath the lens of the microscope any living tissue and find it made up of many little chambers, or cells, as they are called. Within these chambers, or cells, in the living tissue is always found the transparent, jelly-like protoplasm; a tiny piece of the inside skin of the onion, for instance,

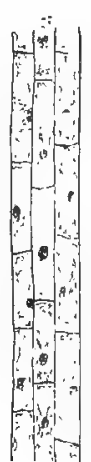
shows very beautifully the cells containing protoplasm of which it is made. 
These cells are cylindrical in shape and lie side by side, each with a spot of condensed protoplasm called a nucleus, and around the nucleus and touching the surrounding cell wall is the transparent protoplasm, looking like the white of egg. The walls of these cells are tough and strong and are made by the protoplasm within.

The cell walls are not alive, any more than an egg-shell is alive. Only the protoplasm is alive.

The skin of the onion is made up of millions of these little cells lying side by side, and if we examine the other parts of the onion we find them each made up of cells lying close together, the only difference being that the cells assume different shapes in different tissues. But all are essentially alike, living protoplasm within, surrounded by a protecting wall.

If, instead of the onion, we were to examine a bit of muscle under the microscope we should find that too made up of cells lying close together. A carefully prepared section of bone would also show us the cell with its protoplasm within, but this time surrounded by a strong fortification of lime. The lime, which forms the hard part of the bone, is not alive, only the tiny drop of protoplasm within the lime fortress is living. This protoplasm has the power to extract the lime from the blood which flows about it and build the bony framework, and this framework as seen under the microscope is almost as beautiful as a snow-flake, with its spicules of lime raying out from the centre. 
Thus each tissue in living things is built up of numberless cells of protoplasm, and in each tissue the cells have a characteristic shape, some of which are portrayed at the bottom of the page.

Sometimes, however, protoplasm exists without any definite form, and has thus been found, a mere layer of slime, at the bottom of the sea.

Again, a cell of protoplasm may exist by itself, not united with other cells to form a tissue. Where it thus exists it sometimes has no cell-wall, is but a speck of protoplasm, living its little life in the water, often too tiny to be visible to the naked eye. Yet this little single cell of protoplasm is as truly a living creature as is a kitten or a bird. For some reason in the one case, countless numbers of cells congregated together and built up a kitten or a bird; while in the other case, there was no such building up; the single cell was destined to live alone.

It takes many tissues and countless millions of cells to form the organs of the kitten or the bird and enable all their various functions to be performed. Then how does the creature possessing but one cell survive? For we
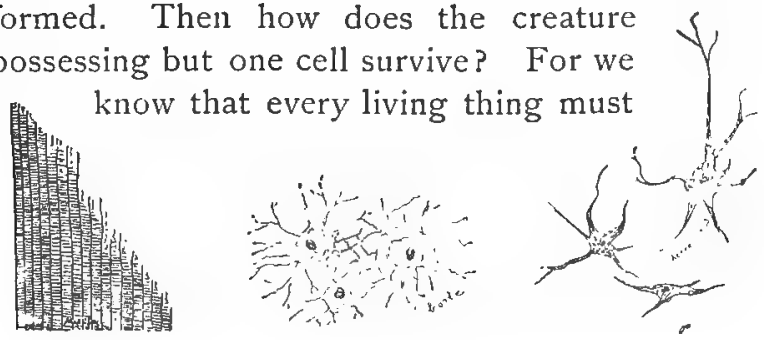
have food and must take the oxygen from the air and nust perform a number of operations within its body.

Imagine a creature composed of but a single cell!

This little being appears to us at first thought very simple; yet when we consider what it accomplishes we are filled with admiration and wonder.

In the first place it must have food or it cannot live; how is it to obtain this food?

The protoplasm of which it consists readily solves the problem; it recognizes its nutriment in the water which flows about it, and exerts an attractive power upon each tiny particle of food, causing it to become a part of the hungry cell. Having drawn food into itself, the protoplasm proceeds to extract from it just what it needs to satisfy its hunger, and discards the waste parts; for it must be understood that hunger does not depend upon sizc, but upon the necessity of the living material in the body to be renewed. A bit of protoplasm so small that it would take a powerful microscope to enable it to be seen at all, has the same need for food that the largest animal has, and if deprived of it would die of starvation.

Besides appropriating its microscopic meal, our tiny cell of protoplasm changes or "digests" the food into a material like itself, and builds this new material into its substance to take the place of the used up particles. 
Some of these single-celled creatures do not even wait for their food to come to them, but themselves go in search of it.

How can this be when they have no legs, no organs of locomotion whatever?

But again the protoplasm is equal to the situation; desiring to move, it will not be deterred by lack of organs, for this remarkable substance has the power of "contractility" as it is called, the peculiar power that muscle possesses, - its power of moving. The protoplasm of the cell that is to move thrusts out a part of itself, a little advance guard of protoplasm, to which the remainder of the creature is then drawn.

So we now see that protoplasm can act where it is, and that it can move to another place. We see that it can digest, or change crude food into body material for its own use. But more than this, it is also sensitive, that is, has within itself something which in higher life develops into nerve matter. Lastly, it has the power of reproduction, which is all important to the continuance of its species on the earth.

Thus the tiny cell has within its protoplasm all the conditions of life and growth and continuance.

There is a little living being, well known to science, composed of but a single cell; whether it is a plant or an animal, who shall say? We call it amceba. It belongs to those lowest forms of life called protozoa, and like all living things has 
the desire for food, which its protoplasm first appropriates, then converts into available material. At a certain period in its existence the amœba obeys the universal law of life, and in place of one amoeba, we have two.

The Future, appealing to the amoba, causes it to multiply its form; and this it does in the simplest way, by merely dividing in the middle and becoming two.

This is the earliest form of parentage, the simplest form of reproduction. This separation of one into more than one is a primal impulse of living things.

Yielding to this necessity the amoba lives on forever, or as long as the earth continues to support life.

It becomes immortal in the scientific sense in which the term is used to denote a continuance of the physical life on earth.

Only it, however, and its nearcst relatives, as simple in structure as itself, achieve the stupendous result of personal physical immortality.

The amoba, by dividing its whole substance, knows no lıss, no death of any part; only violence can sunder it from life.

It resolves itsclf into its own offspring, and nothing perishes.

But this mere dividing of the individual is not always enough, even for the lowly protozoa; forms almost as simple as the amœba seek to renew the 


\section{First Parents.}

vitality of the race by a stronger impulse of life than the individual alone possesses.

So we are told there are times when one singlecelled creature finds itself irresistibly drawn to another.

Its lagging forces are powerfully wakened as it feels the touch of this kindred life, and these two flow together in indissoluble union, as two drops of water might flow into one, and from this union results a stronger and more vital race.

Aroused to momentary intense activity by this new contact, peace follows the joining of the two lives, and as though to express the joy life holds cven to so lowly a creature, the new being composed of two united into one resolves itself into many offspring, thus handing on a more vigorous inheritance to its descendants.

There are many forms of these single-celled creatures, but in all, the story of regeneration is essentially the same.

Some seem never to reproduce themselves without the inspiration of contact with another of their kind.

Some give forth life for a few generations by simply dividing, but ultimately require the renewal that comes from union with another, or their vital power ceases, and death ensues.

It would seem that this expression of what we may in anticipation call love, this attraction to another and fusion with it, is necessary to the continued existence of even the humble protozoa. 
"Even at this low level," says one inspired scientist, "only through the fire of love can the phonix of the species renew its youth."

Love preserves the universe of life, and to many the thought has come, May not love be but another manifestation of the same infinite power which preserves the earth itself in its place, and all the members of the starry host in their places?

For this is the nature of love, - to draw to itself the beloved object.

To the finite mind it may seem a long way from the amœba to the stars; but to the infinite mind, it may well be but a single step. 


\section{Spirogyra.}

\section{III.}

\section{SPIROGYRA.}

I IFE animates the world of plants as it does L that of animals. Low down there is no observable distinction; one cannot tell whether certain simple creatures are plants or animals. And in the beginning there probably was no division of the kind.

Far, far back, as every one knows, there was probably no physical life at all on the earth. In time the surface of the earth assumed a form favorable to the existence of the new activity - life. And then life appeared, but not the

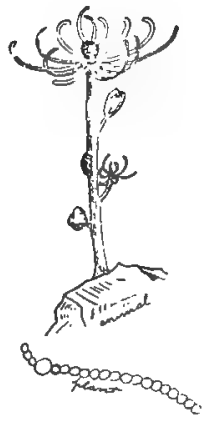
life that we know; it took countless ages for that to emerge from its simple protoplasmic beginning.

What the very first forms of life were, we cannot know; we only know that they must have been very simple; perhaps the beginning was but the formation of a layer of protoplasm with no definite form, such as is yet found in the ocean in some places. Then there may have come into being the single-celled organisms, then the creatures 
made of simple colonies of cells, then the more complex cell-colonies, until finally man himself appeared, the crown to this marvellous expression of divine power which we call life.

As the earth was fitted to receive it, there doubtless came into being each higher form. So the low forms of animal life are in all probability representatives of the earlier forms, and by tracing the development of life from below up, one acquires not only knowledge concerning the structure of individuals, but also concerning the history of the advent of life.

It is probable that plants and animals both came from the same form of simple protoplasm, and were brought into being by the power that makes growth possible, - the same forces acting in both, though expressing themselves differently.

Plants, being able to obtain nutriment directly from the mineral world, probably first assumed definite form, while the animal, dependent upon the vegetable for existence, we believe to have come later.

In plants and animals alike, love as well as life informs and makes beautiful the most lowly of objects.

The green scum of ponds may not seem an attractive subjcct, yet what is more charming to the eye than the delicate threads which form it, when they are seen under the microscope?

Even without the aid of the microscope this 
scum is not to be wholly despised; run your fingers through the water where it floats and you find clinging to them innumerable long, green threads, like the hair of some strange water-maiden. Now put one of these tresses under the lens.

You will find, probably, that you have captured one of the numerous forms of spirogyra, and that these long green hairs lie side by side, parallel to each other, and untangled.

Each filament is composed of long tube-like cells placed end to end; and running in spirais of beautiful form about these cells are bright-green lines, - the chlorophyll, or plant color, which, without the revealing help of the microscope, we see in mass and so rudely that the filaments appear to the naked eye lines of unbroken green.

Lying in the water this simple plant, with no roots, no leaves, takes to itself the nutriment it needs. The protoplasm which forms the internal living part of each long cell absorbs and digests, just as protoplasm everywhere does.

Spirogyra, too, reproduces itself, else whence would arise the bright-green felt-work that covers the ponds so soon?

Life must be sweet even to it, and it will not die. Do not think reproduction in this green scum is a simple matter, for what life is simple? What living thing ignoble?

All the mysterious forces of life dwell in our humble spirogyra, and that attraction, which in 
higher life develops into love, is necessary to its perpetuation.

From a tiny spore these green filaments have formed, quickly absorbing light and heat, and in a short time reaching prodigious growth; then comes a time when the future urgently appeals to them; each cell feels a strange, irresistible attraction to its neighbor cell, and the filaments lying side by side are drawn together by this new magnetism, this incipient love force, irresistibly compelling two to become one. Quietly they have hitherto rested, but now something in each cell

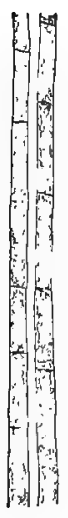
wakens; no longer is it content to be alone. The protoplasm in each cell yielding to this new impulse, collects together, concentrating itself into one compact mass.

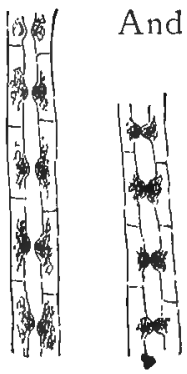
feeling the desire of the living protoplasm within, reach
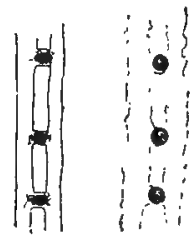
out to each other! At last

they meet; they unite; all obstruction having given way, the protoplasm from one cell flows into that of the other, the two thus becoming one. Concentrated into one compact spore they are saved from death, they go on in life. 
The cell-walls, now lifeless, useless, perish. Those vital spheres, each formed of the united protoplasm of two cells, fall to the bottom of the pond. They fear neither cold nor drought. The pond may dry up, the ice may form about them; love has triumphed; through it their continued existence is assured.

At the coming of the spring rain, the warming of the spring sun, the new life unfolds; from the germ of the spirogyra that was, there springs to life a new filament with its beautiful emerald bands, and again the green scum is seen over the pond.

The world is full of invisible as well as visible forms of life, thus living and reproducingr. They float in the air, are found in the water. Microscopic creatures of simple structure and beautiful and rare forms live their little cycle of life, meet, unite, are physically immorta! through the life they hand on to future generations.
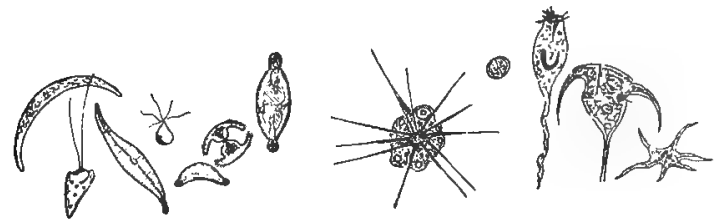


\section{IV.}

\section{THE DIVISION OF LABOR.}

$W^{\text {HEN the amoba and certain other one- }}$ celled forms of life reproduce by simple division, we see the whole substance of the creature resolving into its offspring.

When the amœba becomes two, which of the two is parent, which is offspring? W'e cannot tell. In size they are the same, in structure the same, there is no childhood on the part of one, no parental care on the part of the other. The amœba, in multiplying, gives all; its whole substance is involved in the change. So when, to further the ends of reproduction, two single-celled beings unite, which is father, which mother? Again the question cannot be answered.

Both parents are alike, except in this: in some way different magnetisms appear to animate them; although seeming to us alike, they apparently excrt upon each other the powerful attractive force of opposite poles of the magnet. 


\section{The Division of Labor.}

In the multiplication of the amœba, as has been noted, there is no death, merely the going on of the whole mass in different directions.

So in the spirogyra found in the scum of the ponds, all the protoplasm of one cell passes into and unites with all the protoplasm of the neighboring cell; but the result is not quite the same, there is some waste, some death here; for when this union has taken place, the cell-walls, no longer useful, no longer kept intact by the contact of the flowing protoplasm, disintegrate.

They are empty houses, their tenants forever departed. True, all that was living in them is still living; the cell-wall in itself was no more alive than is the end of one's finger-nail; the protoplasm built and nourished it, and when ready, left it. And yet, when the spore formed there was an end to the green filament, that form of its existence at least perished. Only in its seed did it live, and through that develop into green filaments another year - not the same filaments, however.

Simplest of all, the amœba reproduced by division, without the loss of any part of its substance, and without undergoing any change of form. Then we see the spirogyra preserving its whole mass of living protoplasm, but giving up its green-banded walls.

This extreme simplicity in multiplying does not belong to all of even the one-celled organisms, however, for some devote but a small portion of their 
substance to the renewal of their race. Instead of dividing in two, or devoting their whole store of protoplasm to the production of a germ or spore. they bud off a small portion, or a number of small portions from the surface of the body, and each of these portions in some mysterious way contains all the possibilities of the parent life, and in time grows to the likeness of the parent.

By thus budding off but a small portion of its substance, the creature retains its own individuality independent of its offspring. But the end is death, for the parent that is left cannot go on living forever, as do those parents who actually become their own offspring.

What is left of the parent after the reproductive portion has been budded off in time perishes; only this cast off portion lives to develop in its turn into the parent form, and repeat the story; that part which it buds off as offspring, or seed, living; the remainder dying.

Thus on and on passes the vital reproductive material, the form of the parent constantly falling away and perishing, the reproductive material alone persisting and continuing the race.

The individual body, in the higher life, per. ishes; the race, through the reproductive material, continues.

The habit displayed by some of the single-celled creatures of budding off but a small portion, which is endowed with power to become a perfect form, 


\section{The Division of Labor.}

suggests the higher forms of life, where the animal or plant is composed, not of one cell, but of many, among which is established a division of labor.

When the single-celled organism reproduces, it divides and becomes two, as seen in the amœba. Each division is a complete individual. In the higher forms of life the creature starts as a single cell. Every living thing, even to man himself, sets out on the life journey, as a single cell. This cell divides, but instead of the two cells thus made separating from each other, they stay together. Each of the two cells then divides again, and the group of cells, instead of separating, stays together.

The diagram at the bottom of the page may make clearer how the cell is able to build complex forms. There is seen the single cell, then the cell after division, then a simple thimble-like form built

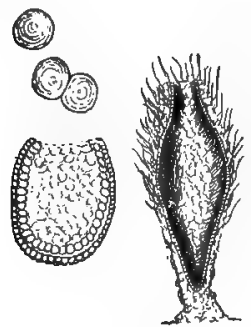
of many cells, then a little animal that grows in the sea, in which the cells have assumed several different forms, and final-

ly a worm-like form in which the creature is but a long tube, with another tube running through the middle. This last form has many different sets of cells doing different work. For, unlike the 
single-celled creatures, where all the functions of life were performed by each cell, these complex forms give rise to cells which do not perform all of the life functions, but only part of them. Thus in the higher animals and plants certain cells are set apart to perform certain functions, and these cells are freed from all other duties.

In our own bodies, for instance, the muscle cells do all the moving. The bone cells, the nerve cells, have no power of motion; only as the muscles move them do they change their place.

The nerve cells, on the other hand, have confided to them the power of sensation and of directting the motion of the muscles.

So each kind of ccll has its special work, which it does for the whole community, thus relieving all other cells of the necessity of doing that special work.

This division of labor, however, does not prevent the relation between the different kinds of cclls from being very close. On the contrary, the relationship is so close that if an accident happen to one cell or one set of cells, all the rest of the body may suffer because of it.

Where there is this division of labor among the cells of the body, reproduction cannot involve the whole creature, as it sometimes does when the whole creature consists of but one ccll.

Consequently all higher forms of life close their career in death, their physical life continuing only through their offspring. 


\section{The Division of Labor.}

Only the higher life, emerging from the immortal single-celled form, is blessed by consciousness and - death.

Death! how sublime the thought when it is recognized as the sign of a higher form of life!

The amœba, unfeeling, unknowing, lives, grows, divides; goes on endlessly, with no development, no enlightenment.

In the more complex form something wakes to consciousness; the creature lives, it grows, it develops, it understands - it dies.

Because it is complex, intelligence dawns.

Because it is complex, it dies. Beautiful death! - sign of the sublime in life.

The more complex beings, like the simplest ones, bud off portions of the body for purposes of reproduction; unlike them, however, the budding takes place from the inner part of the body instcad of from the surface.

These inner portions so budded off in time may develop into forms like the parent.

The jelly-fish, which may be seen at any seaside, is an illustration of this. There is the body-wall; the cavity within; and from the latter a mass of reproductive cells budded off. There are several of these "buds" in each jelly-fish, and the story of reproduction told in their development is wonderfully interesting and instructive, but unfortunately it is very complicated; so we will turn from the pretty transparent forms floating like bulbs of 
crystal in the water to another form of life, much less beautiful to look at, but extremely interesting to the student. This is the Ascidian, or Sea Squirt, so named from its habit of suddenly contracting when handled and treating its tormentor to an unexpected jet of sea-water.

It is an uncolth creature, oblong and lumpish, sometimes too small to handle readily; sometimes a foot or more in length. In early youth moving

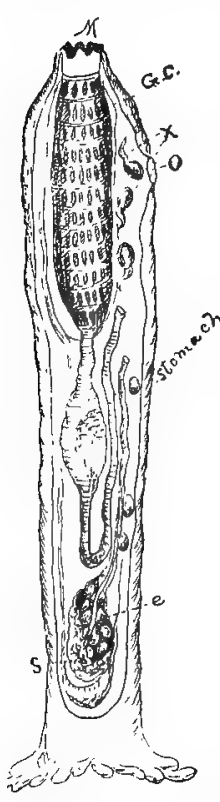
freely through the water, as it grows older it firmly attaches itself to the rock or something else under water, and stays there to the end of its days.

Let us look at one of the larger kinds. We find it has a thick, skin-like covering with two openings - one at the top, $m$; one at the side, $o$.

The one at $m$ opens into the gillchamber, $g$. c., and is the mouth, through which water passes to the gillcliamber, then out through the slits of the gill-chamber into the body-cavity.

At $o$ is the opening from the bodycavity to the surrounding world of water. In the body-cavity we see, besides the gill-chamber, certain other organs, among them a number of round bodies, $e$, which have been budded off from the inside of the animal's body. These are reproductive cells, familiar to us under 


\section{The Division of Labor.}

the name of eggs. But lying close to the eggcells is a gland, $s$, from which are sent other buds, much smaller than the eggs. These ripen and fall with the ripe eggs into the water of the bodycavity.

When these tiny particles and the eggs are set free together in the water, they feel the same attraction toward each other that the two uniting cells of spirogyra felt, or the two protozoa when they were so irresistibly drawn to unite with each other.

The egg-cell of the ascidian has not enough vitality to develop unaided into an ascidian, neither has this smaller cell. If like the two protozoa they unite, however, the result can be achieved.

It would seem as though this complex ascidian could not impress the image of all its parts upon one set of cells, but that the great labor of producing an ascidian must be shared; so it supplies two sets of cells, which by uniting become able to reproduce the parent form.

The smaller particles are called sperm-cells and represent the male element, while the egg-cells form the female element.

Free to move about in the body-cavity the sperm and egg cells are attracted to each other; each egg-cell is penetrated by a sperm-cell, and from this union develops the young ascidian which appears at $x$, wriggling about, unattached and free, in the 
water of the body-cavity of the parent before it finally finds its way out at $o$ into the ocean. There its free life soon ends, it settles down on a rock and assumes the monotonous life of an adult ascidian.

The egg, by union with the sperm-cell, has gained power to develop; it has been "fertilized," or rendered able to produce the parent form.

The sperm-cell, too, by union with the egg-cell, is saved from perishing; it is enabled to express the characteristics of the creature from which it was budded in the new creature which springs from the egg it has fertilized.

In our ascidian, as well as in many other low forms of life the two kinds of cells are both budded off by the same individual, which thus contains both male and female elements. Such a creature, uniting as it does the tivo sexes in one, is called a hermaphrodite.

In some cases, however, even among low forms of life, one individual gives rise to but one lind of reproductive material, another separate individual supplying the other kind.

The sexes are thus scparate, the egg-cells being produced by the female, the sperm-cells by the male.

In those low forms of life where the eggs of the female and the sperm-cells of the male are cast forth into the water, they float about until they find each other, or failing in this, die, - a very wasteful and prccarious method of reproduction. 


\section{The Division of Labor.}

The vast amount of reproductive material produced and apparently wasted in the lower life is one of the most striking facts to the student of nature, and it was long before the significance of this tremendous over-fertility was understood and found to play a very important part in the development of life.

Oftentimes in the lower though complex forms of life the parent literally resolves its whole substance into reproductive material, the maturing of this material causing the death of the parent; for instance, in certain very low forms the parent becomes a mere shell to hold the progeny, and when they mature bursts open to free them, and thus expires. This is the case with the simple Orthonectid which, when mature, is little more than a cup of eggs. In certain forms of worms the female breaks up upon liberating the egg-cells, and even as high as the insects the parent is in some cases sacrificed by the development of offspring.

Offspring is in all life but a portion budded off from the parent; sometimes, as we have seen, being a large portion, again but a very small one.

In the lower forms of life this budding for purposes of reproduction may take place in almost any part of the body, but as the creature becomes more complex, reproduction is restricted to certain tissues which are set apart to do that work, and are peculiarly adapted to it.

As we have seen, both male and female give off 
certain cells, which, though they may be powerless in themselves, by union with the cells given off by the opposite sex, have power to produce offspring like the parents.

But even in creatures which have achieved considerable complexity of structure, and which reproduce normally by the production of egg and sperm cells there is sometimes a form of reproduction which recalls the simple method of the amœba. A certain ringed marine worm, for instance, merely sprouts, as it were, from the side or the end, and

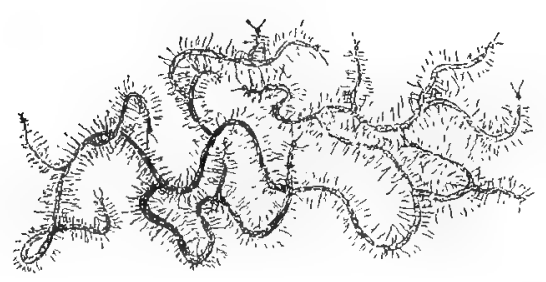
there is formed sometimes quite an intricate network of those strange creatures.

Another seaworm, again, when a certain length has been reached, develops a head at one joint and a tail at the preceding onc, and when this development is completed the creature is composed of two perfect worms which fall apart. Sometimes

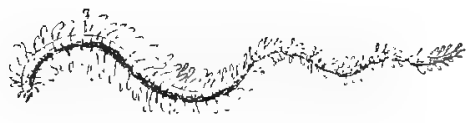
several of these new worms are formed before separation takes place, the result being a chain of forming worms.

In the upper registers of the scale of life this budding of the parent into offspring which do not 


\section{The Division of Labor.}

have to go through the egg transformations, is never seen. The egg, however, in ccrtain low forms, éven as high as insects, has the power sometimes to develop without the aid of the sperm-cell, - its store of nutriment and vitality is sufficient to carry it through the difficult transformation, but the tiny, innutrient sperm-cell cannot save itself by unaided development; it must always unite with the egg-cell if it is to continue its existence.

In all the higher forms of life, however, neither egg nor sperm cell alone can achieve development; yielding to the vital attraction which draws them together, they unite, and from this inexplicable union comes power to produce a new and perfect creature. 


\section{V.}

\section{FISH LIFE.}

$\mathrm{J}^{\mathrm{N}}$ the ascidian and other low forms of life the 1 eggs and sperm-cclls are dropped into the

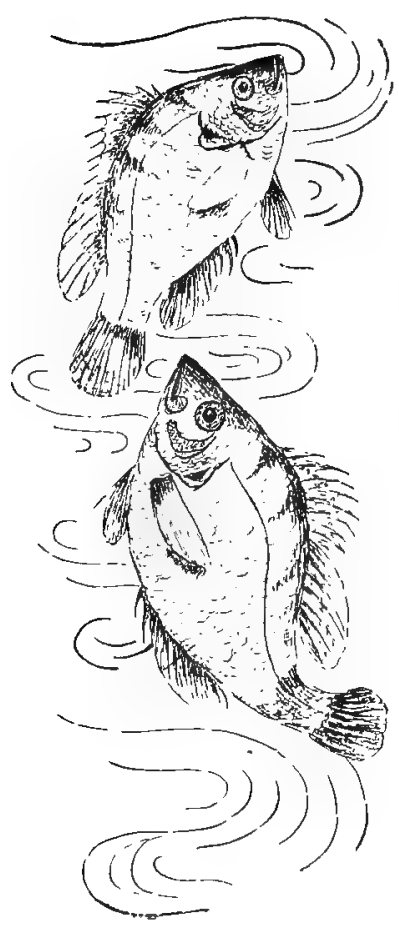
water to float about and find each other as best they may. The mysterious attraction of one sex for the other is felt by these atoms alone. The full-grown parcnts from which they spring live in cold indifference to this interchange of life; they have nothing to do with love, except the supplying of these love-seeds, that, moving about in the water, seek each other.

But higher in the scale of life, where the two sexes are separate, the attraction felt by eggcell and sperm-cell is reflected in the parents themselves, and there comes into existence that powerful and subtle force known aj sex instinct.

Darting about among the ascidians and the jelly-fishes, for 


\section{Fish Life.}

instance, there are creatures that show no indifference to each other. The slim, swift fishes cutting the water so gracefully with their boat-shaped forms tell another story of life and love.

As far as the origin and structure of their reproductive material is concerned, there is no essential difference between them and the ascidians; that is, eggs and sperm-cells are budded off from a certain part of the interior of each individual. Both eggs and sperm-cells are not found in the same fish, however. We have here, as in all the higher life, male and female.

In the female are found the egg-cells, which are produced by a certain tissue forming a double sac, shaped something like an old-fashioned silk-purse. Each lobe of this sac is called an ovary, and the two ovaries are a definite and permanent part of the creature's body. They produce the eggs, or ova, and these when ripe break away from the ovary, and finally pass out of the body of the parent into the water.

The eggs keep forming in the ovaries, however, so when one set is ripe, another is growing. Most people are familiar with fish eggs under the name of roe. Those of the shad are considered a delicacy, and in the South the roe of the mullet is dried and kept for future use. The eggs of these fish, as is well known, are about the size of a small pin-head. In smaller fish they are often a good deal smaller, but seldom, like the sperm-cells, so small as to be invisible. 
In the male fish are found sacs similar to the ovaries of the female, containing the tiny spermcells, so tiny that they cannot be seen without the aid of the microscope.

They are mixed with a milky fluid substance, also secreted by the sperm-sac, so that the whole sperm-sac is not unlike the ovary in size and consistency.

This fluid is well named the fertilizing fluid, containing, as it does, the sperm, or fertilizing, cclls.

The reproductive cells at certain seasons of the year ripen, and the fish are then ready to perform their reproductive functions.

The ripe egg-cells have stored up within them an incredible amount of vitality, for in each is almost the possibility of becoming a perfect fish; they are thrilling with life and unexpressed power, and the presence of these life-cells imparts a strange and powerful magnetism to every cell in the fish's body, as the presence of a strong magnet affects every particle of iron in its neighborhood.

In the male fish the microscopic sperm-cells are also ripe and thrilling with life, and they send their message pulsing through the whole fish-body.

The male and female, thus powerfully charged with opposite attractions, are irresistibly drawn, the one to the other.

As is the case with other charged bodies, this excessive accumulation of a particular kind of force 


\section{Fish Life.}

is capable of being discharged and of leaving the body again neutral.

In addition to the great emotional disturbance, the tremendous activity of the reproductive season causes marvellous changes of structure to take place, changing the form in various ways, and often causing the skin to glow with brilliant colors.

These changes continue until the reproductive elements are fully ripe and ready to be eliminated.

When this time comes, the female fish instinctively secks a spot suitable for the development of her offspring, and in depositing her burden of eggs also becomes free from accompanying emotional and physical phenomena.

The eggs once laid, the characteristic vitality of the breeding season subsides.

This period of intense activity is over. The fire is quenched, calm and a greater stability reign through the cells of the body.

The male is even more affected by the reproductive activity; overwhelmed by the force of the vital action that so possesses his whole being, he too finally discharges the battery by freeing himself from the presence of the intensely vital spermcells.

Powerfully attracted by the female, he accompanies her to the breeding place, and when she has laid the eggs, affected by some subtle instinct of love and desire for life, he pours upon their waiting, uncertain life the fertilizing fluid which is to stimu- 
late their power of growth from a possibility to a certainty.

The fertilizing fluid once eliminated, peace reigns. The brilliant coloring fades again to the ordinary garb; the season of love, of highest inspiration, of most. tremendous vital activity, is, for the time, over.

Marvcllous is this condition while it lasts, fortunate that its period is bricf, or how could the fragile form sustain this raging fire? It would be overwhelmed, consumed; it would literally die of love, as, in truth, it somctimes does.

The fervor of love over, the parents no longer fecl the same attraction for each other's society. The ordinary course of life suffices.

But when love ceases in them, it begins its marvellous work in their offspring.

The egg-cells lie waiting, passive but eager. The sperm-cells, active, cager, seek to become united with the egg-cells.

In each egg-cell it may be said is half life; in cach sperm-cell the other half; and these two halves in uniting become whole.

Egg and sperm cells differ from each other in other ways than the mere possession of opposite attractive powcr.

All egg-cells are essentially the same, no matter what creature may be their source, while spermcells differ greatly in form and activity.

Compared with the sperm-cell, the cgg-cell is 


\section{Fish Life.}

large, quiescent, and contains a large amount of nutriment, which goes towards the formation of at least the first stages of the young animal. It is usually spherical, or nearly so, in form.

The sperm-cell is small, active, contains very little nutritive material, and is generally composed of a larger part or "head," and a long slender contractile "tail," "which," we are told, "working behind like a screw, propels the essential head through the water or along the ducts."

Some of the forms of the sperm-cell are drawn at the side of the page; beginning at the top and reading down, they are: thread-worm, crayfish, sponge, lobster, crab, dog, rabbit, mouse, dog, pig.

The sperm-cell of the human being is of the same nature, consisting of a blunt, oblong " head," and a long, slender, whiplike portion.

Thus, while the egg-cells of different creatures are constant in form, differing mainly in the amount of nutriment they store up, the sperm-cells are extremely variable, and while the "head" and "tail" characterize those of most animals, "occasionally," we are told, "there is a departure from the predominant phase of celllife. Thus in the thread-worm, the sperm 
has a blunt, pear-shaped form, and exhibits slight amœboid movements. In some crustaceans and other arthropods, the cell is even more quiescent, and may exhibit curious forms such as that figured for the crayfish. The relatively dominant activity may, however, wake up, and the sperm exhibit active amœboid movements."

The sperm-cells, be it remembered, are so minute as to be totally invisible to the naked eye. The fertilizing fluid of the fish, for instance, gives no hint of the presence of the sperm-cells until it is viewed through the microscope. In studying nature one soon comes to understand that size is merely relative and essentially unimportant. A creature invisible to the human cye may be a veritable mammoth compared to another creature so tiny that the strongest powers of the microscope have to be used to discover it. And so the spermcells, although as invisible to the naked eye as though they did not exist, have an organization and a fleeting life of their own, - a life less fleeting, and fraught with great results, if they meet with conditions favorable to their development, and can, by union with an egg-cell, help to create a complex form.

Upon examination and comparison of egg-cell and sperm-cell we are particularly impressed by the difference in their power of independent motion. Activity is the law of the sperm-cell; passizity, of the egg-ccll. 


\section{Fish Life.}

These characteristics of the reproductive elements are expressed through the whole individual as well, - the female being, as a rule, passive; the male, active.

The passive female cell, large and well nourished, lies quiet; the active male cell, irresistibly allured by its presence, moves eagerly to join it.

When dropped into the water the egg-cell of the fish, alive, magnetic, but motionless, awaits the coming of its preserver. He will come; she need make no effort to go to him.

The sperm-cell, when dropped into the ivater near the egg-cell, exhibits no such calmness. It shows great unrest, and eagerly seeks the egg-cell, which it strives to penetrate.

As there are many more sperm-cells than eggcells, and as only one sperm-cell, it would seem, can unite with each egg-cell, it follows that but few of the sperm-cells are able to continue life.

The egg-cell has but one point of ingress, and this a sperm-cell finally discovers.

Under the microscope these active forms have been seen eagerly moving around and around the egg until one, more fortunate than the rest, finds admission and dissolves into the substance of the egg, - not to be finally lost, however, for, as we know, this inexplicable union results in the growth of a new creature like neither parent, and yet like both, each cell having given to the new life certain 
characteristics of the creature from which it was derived.

It is a subject of never-ending wonder that within each of these tiny reproductive cells lie hidden all the peculiarities of the parent from which it came.

In a trout egg, or a trout sperm-cell, is contained trouthood. Form, size, spots, habits, all are in some mysterious way impressed upon these atoms budded off from the body of the parent.

And the mystery is overwhelming when we reflect that not only can the tiny reproductive coll transmit the peculiarities of the creature from which it came, but also those of ancestors many gencrations removed. 


\section{VI.}

\section{CRUSTACEANS.}

VERY radical and far-reaching is the reproductive change which takes place during the breeding season. Even in the higher life great parental sacrifice is involved, and the whole body undergoes profound modifications under the sway of the reproductive force. During the breeding season life speeds along as it were under high pressure, the vital activity prodigious ly increased in certain parts of the organism, and correspondingly decreased in others. It is a law of life that excessive activity of one

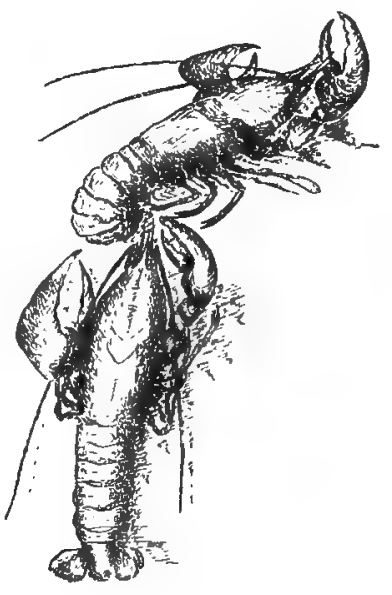
system is accompanied by decreased or suspended activity of others.

So, for instance, when the reproductive activity is at its height the digestive and assimilative activities are partly or wholly suspended; this may be 
a condition of longer or shorter duration; where it is of long duration it produces as a rule a fatal effect. The creature undergoing such loss and not repairing it by added nutriment cannot regain its strength, and its life terminates.

A terrific exhaustion accompanies the reproductive act in our fishes. After the loss of a million or more eggs, accompanied by diminished vitality in all the cells, there is not much left of a cod! Otten the male salmon does not even survive the phenomenal changes which come over him at that period. These changes are often accompanied by longsuspended nutrition. He loses his appetite, and during the period of greatest reproductive activity, when the most powerful demand is made upon his resources, eats little or nothing, thus failing to make good the loss. He is so brimful of activity in certain parts that unusual growths result; his teeth get long, his mouth grows long and hooked, so that sometimes he cannot even close it; his scales disappear, sunk in the spongy skin which grows up about them, his color changes from silvery to rosy red, or a darker red, or even to a blackish color, according to his varicty; and with these physical changes comes a no less marked emotional activity, - he grows fierce and irritable, and indulges in destructive combats with his fellows.

These strange growths and changes, as has been noticed, take place at the expense of the material 
already in the body. His own individuality is apparently of no value; he finds himself in the grasp of a power far greater than himself. He no longer belongs to himself, but to his race, and unconscious of what animates him and threatens his very existence, yields himself to the cosmic force which through him reaches out to that greater and more important fact in nature, his race. That he be preserved is not essential; that his race continue is all-important.

In the female, analogous changes occur, though they are less marked.

As a rule among all creatures, the tissues of the male are, like the sperm-cell, characterized by more intense activity, by greater tendency to change, than are those of the female. She is structurally more quiescent, he more active.

When the breeding season approaches the salmon animated by a gencral impulse, leave the sea in great numbers, and hasten up the rivers. Sometimes for hundreds of miles they go, resistlessly impelled by the power within. Overwhelmed by this vital activity they rush along, over rapids, over rocks, - bruised, mangled, never stopping, eating no food, intent only upon the one supreme act of their lives.

Finally, they select their breeding-place; the eggs are laid, the fertilizing fluid poured over them; they are covered with stones and gravel by the parents, and left to their fate. 
So great is the fatigue of the salmon that go lons distances, and so destructive the changes undergone by the too powerfully affected male, that few of the latter survive the ordeal.

Like certain of the insects, a brief season of intense love is followed by speedy death.

The salmon that stay near the sea survive the reproductive act, though they arc much depleted by it, and both sexes are for a time rendered unfit for food, so great is the loss they undergo.

The spawning season over, if they survive the crisis, the fish regain appetite, and in timc are plump and oily again, - a condition which voracious man renders almost as fatal to them as is that of the breeding season.

The depletion of the fish is chiefly due to the vast amount of reproductive material it elaborates. Its condition in life is such that there is great waste of this material, only a comparatively small portion living and developing to maturity.

The fish drops her eggs into the water, the male covers them with the fertilizing fluid, and they are left, tender atoms of life, to mect and overcome incredible perils.

Unprotected, the eggs, and even the young fish, fall a prey to other creatures, for very few fishes protect their offspring.

Some do; the graceful stickleback, for instance, builds a dainty and elaborat? nest, but most fishes pay no attention to the eggs after having laid them 
in a suitable place. And besides all the other water creatures that relish fresh eggs, the fishes themselves are sad cannibals.

Although they will not eat their own eggs, many do not hesitate to devour the eggs of other species, wherever they can find them.

So the million eggs of a cod are none too many to insure even a small progeny to each fish.

Not all creatures are as prodigal of life as are the fishes, however.

Many have most elaborate structures for the preservation of the reproductive cells until they are hatched.

The lobster, for instance, cannot trust its precious life-cells to the tender mercy of the creatures of the deep. It preserves its egrs and sperm-cells, and ingeniously adapts its jointed body to the uses of a nursery.

Recall the structure of the lobster in order to understand this.

There is a solid front portion of the body to which the legs are attached, and a hind portion which is in rings, like the body of a caterpillar.

Two little leaf-like parts, or swimmerets, are attached to the under side of each ring. The openings of the egg-tubes are found on the inner joint of the third pair of legs, counting from the back; and in the male the openings of the tubes to the sperm-sacs are found on the inner joints of the last pair of legs. In the male the last two pairs 
of swimmerets, instead of being soft and flexible, are hard and horny, and assist in conveying the sperm to the cgg-cells, so that the eggs are fertilized before they leave the body of the female. Thus is obviated the great waste of male reproductive material, which is sustained by so many of the fishes.

After being fertilized, the eggs are laid, but instead of dropping into the water they adhere firmly to the swimmerets of the female, which are somewhat broader than those of the male, and during the breeding season covered with a sticky substance which glues the eggs fast until they hatch; when the tiny lobsters, in turn, cling to the protecting swimmerets of the mother until able to care for themselves.

Moreover, to protect these precious eggs and helpless young from being scraped off as she moves about, or snatched off by hungry and heartless creatures, the lobster doubles her body under, as lobsters know so well how to do, and kceps it doubled, thus forming a safe asylum for the brood.

Thus also in the lobster do we find sex modifications besides those of the reproductive tissues, the male swimmerets being changed into horny "claspers," to assist in the felicitous disposition of the sperm-cells; and the female swimmerets being broad, leaf-like, and covered with a special secretion used to attach the eggs. 
Some of the crustaceans - which is the name of the large family to which the lobster belongshave skin changes which remind one of what happens to the salmon during the breeding season; only, these skin changes are utilized in a very clever way, for they form a receptacle where the eggs are deposited as in a nest, and in some of these a fluid is secreted which is used as food for the young!

Thus the parent is enabled to perform the most perfect parental functions, and in her own body find home and nutriment for her helpless descendants. 


\section{VII.}

METAMORPHOSIS OF INSECTS.

STRANGE as it may seem to the casual ob. $D$ server, first cousin to the lobster's family is the great family of Insects; a wonderful family in its variety and complexity, and particularly remarkable in its reproductive organization.

Life finds its culmination in love, nowhere more wonderfully than among the insects.

With many of them it is literally true that to love is to die. This is so, we remember, with the spirogyra; it is so with countless of the low forms of life; even among the fishes the great transformation is often followed by death; but nowhere is this sequence more tragic than among the insects.

Strange indeed is the life of the insect! In the vast majority of cases its whole existence appears to be but a preparation for a brief moment of transcendent life, - followed speedily by total extinction.

As an egre it starts upon its precarious career. Its parent places it as well as she can; places, 


\section{Metamorphosis of Insects.}

then leaves it to find its own way through the strange world it has never seen, while she, as a rule, her destiny accomplished, departs to dic.

From the egg there issues, very often, a helpless, wingless creature; from the egg of a butterfly creeps forth a caterpillar; from that of many beetles comes a soft and tender grub; from that of a fly there springs a maggot.

These tender larvæ, wingless, earth-bound, literally eat their way through the world. Voraciously they store up nutriment for the change that is to come, growing so rapidly that they soon find their skin too small to hold them, and are obliged to split it open and crawl out, sometimes satisfying their voracity by devouring the cast-off garment.

This happens several times in the course of the creature's larval life, perhaps from three to ten being the most usual number of moults, though Sir John Lubbock assures us that he counted twenty-one moults in a may-fly!

Some insects pass through this lowly larval stage in a few days or weeks, others remain thus undeveloped for a year, while still others require several years to eat themselves into condition for the next change, the pupa state, which is one of seeming rest.

When the time for this new change arrives, the voracious larva loses its appetite, grows restless, and finally spins for itself a silken cocoon, or wraps itself in chips or bits of earth, or buries itself in the 
ground, or otherwise, according to its nature, provides for a season of external inaction.

This inaction is only apparent, however; one looks at the pupa and finds the legs gone, while the jaws and other instruments for obtaining food or working its way into hard substances have disappeared. It is but a well-swathed mummy in appcarance. A living mummy it soon proves, however; for though so quiet outside, within, the most remarkable changes have been taking place.

If it be a caterpillar, all the nutriment and strength stored up by its much converting of food into caterpillar is here made use of in transforming the unwieldy larva into the graceful butterfly.

In time it shakes off its pupa case, and steps forth resplendent; winged, active, bright, and beautiful, it flashes through the air.

In this state it is called an Imago, concerning which the "Century Dictionary" says: -

"The name is due to the fact that such an insect, having passed through its larval stages, and having, as it were, cast off its mask or disguise, has become a true representation or image of its species."

Having cast off its disguise! Having lived successively through state after state which bore no resemblance to its final form, it entered into its perfect self!

Think of the metamorphoses of a butterfly! 


\section{Mitamorphosis of Insects.}

First an egg, then a caterpillar, then a motionless, mummy-like form, then a winged creature.

From lowly earth forms it rises to a condition which almost transcends physical existence. It has cast off the implements of its lower life; the clumsy feet, where are they? the horny jaws? there is no trace left, - delicate are the organs with which it walks over the flowcrs; gone is the ugly mouth with its cutting and grinding parts; instead, a long and thread-like tube is coiled up like a watch-spring, to be uncoiled and daintily thrust into flower depths to draw forth nectar. For a few brief hours it is one with joy and light and beauty. It can leave the earth, it can drink the honey of flowers.

Its old work-a-day life is forgotten; it is more a spirit than a body.

And this resplendent form, this winged beauty, is its vestment of love.

The great passion animates it only in this form.

It has blossomed into love, and through love passes on to the other great transformation death.

Love is the climax of its life; its fate is to live and love for a bricf season in joyous unconcern, sipping honey from the flowers, glinting the sunlight from its resplendent scales.

And may not a few hours of this life be worth untold ages of creeping in the dust, of lying insensate in the earth? 
To man one vision of God is worth æons of unhallowed life; one great thrill of inspiration, of knowledge, is worth years of sordid common sensation.

And is not the butterfly too, in its glorified state, aninated by the same transcendent joy of life, of nearness to the Infinite, that make its few final hours of life and love count as ages of less exalted existence?

But now for the end, for cluse upon life is death; love is to end in oblivion; or is this transformation, death, but another pupa form, in which the crude earth vestment falls away from some finer essence of being?

Egg, larva, pupa; through these lowly forms the butterfly has passed, finally to merge resplendent as Imago, the image of the specics!

In this transfigured form love thrills the winged creatures, and to love they now give up thcir lives. They approach each other; in rapid flight through the air they meet, they embrace; a bricf period of this marvellous love-flight crowns their winged life, and then the drama of earth has been played to the end.

In them life culminates in love; there is no beyond but that other strange life, that new metamorphosis which man calls death.

In those bricf moments of supremest love is exhausted the whole reservoir of physical strength which the creature has so laboriously accumulated. 


\section{Metamorphosis of Insects.}

It lived, maybe several months, lowly and uninspired, preparing for this fleeting and wonderful expression of its existence.

Faint, sated with all that life can give, totally exhausted by this final, supreme act, the male passes from his brief love-flight to the inexorable and mysterious realm of death.

How sacred, then, does this act of love appear! Love and Death, the two great mysteries of earthly life, linked in this primal, unexplained relation, the one to the other.

The female hastens to deposit her burden of eggs upon some plant whose foliage will be useful to those dear ones whom she will never see, and then she too passes on to extinction.

Some insects live for several years in the larval stages, and then acquire wings, and live and love for a brief period, in that short space concentrating and consuming the vitality it has taken years to accumulate.

Tragic indeed is the tale of the mayflies; for two or three years the larva live in the mud under stones or among grass in the bottom of running streams, their voracity armed with long, hard, sickle-shaped jaws, with which to seize small aquatic insects.

Finally they emerge into the imago state, delicate, fairy forms on gossamer wings. Gone are the terrible jaws, a mere trace of a mouth remaining, for they will never again taste food. All that 
is laborious lias passed away; only two things remain for them: love, isolated from earthly affairs, and death, the mysterious companion of love.

They will flash in the sun but a few hours. Delicate as morning mist they cmerge from the

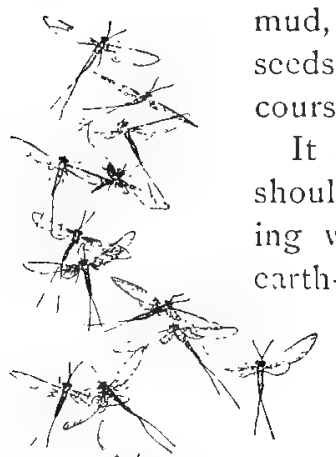
mud, love, then give back to earth the secds of their love, and dic, all in the course of a short summer day.

It is not surprising that the ancients should have seen in the butterfly, emerging winged, beautiful, from the lowly carth-bound chrysalis, a symbol of the human soul.

The Greek word "psyche" means both soul and buttcrfy. And in Greek mythology we find the beautiful maiden Psyche, the personified and deificd soul, often represented with the wings of a butterfly.

In this beautiful fancy of the old Grecks, Psyche, as is most fitting, is the beloved of Eros, the God of Love, who also is winged.

Speaking of the final transformation of the insect, Michelet, in his book entitled "The Insect," says:-

"Love is winged. Mythology is perfcctly in the right. This is verified in the proper sense and without metaphor. In one brief moment nature displays a restless anxicty to fly towards the 


\section{Metamorphosis of Insects.}

beloved object. All creatures rise above their own level, all mount toward the light, on the pinions of desire. The internal fire is also revealed in glowing colors. Every one decorates his person, every one wishes to please.

"The butterfly apparently looks upon you with the great velvety eyes which adorn its wings. Bectles of every species, like mobile stones, astonish by their brilliant reflexes, their burning vivacities. Finally, from the bosom of the shadows bursts the flame of love, naked and unveiled, in flashing stars!

"At such a moment it accomplishes the strangest transformations, and from the humblest masks issue, in violent contrast, the superbest individuals.

"A dull larva of the morass, which lives only by stratagem, becomes the brilliant amazon, the agile winged :varrior, called Demoiselle ${ }^{1}$ (libellula). It is the only creature of its tribe which expresses the complete liberty of flight, holding the same rank among insects as the swallow among birds. Who has not followed with attentive gaze its thousand varied movements, its turns and returns, and the infinite circles which it makes with azure and emerald wings on the meadow or over the waters? A flight apparently capricious, but not really so, for it is a chase, a rapid and elegant extermination of myriads of insects. What seems to you a pas-

1 Dragon-fly, Devil's Darning-needle, Mosquito Hawk are the common names for this insect. 
time, is the greedy absorption with which this brilliant creature of war feed; its season of love.

"Do not believe that these riches are simply the gifts of genial climates; that these glittering festal garments which they assume to love and die in are only the sheen of the sun, the all-powerful decorator, which with its rays intensifies the enamel and gems we admire upon their wings. Auother sun a sun which shines for the whole earth, even for the ice-regions of the pole - profits them far more considerably. It exalts in them the inner life, cvokes all their powers, and, on the given day, calls forth the supreme flower. Yonder scintillating colors are their visible encrgies which become speaking and eloquent. It is the pride of a complete life, which, having attained its climax, displays its

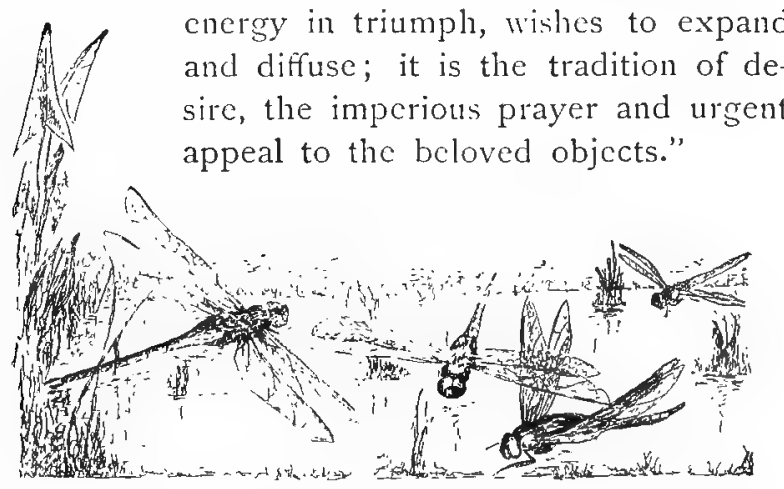




\section{VIII.}

REPRODUCTION OF INSECTS.

$\mathrm{D}^{\mathrm{u}}$

URING the period of transformation from egg

to imago the internal organs as well as the external paits of the insect undergo profound changes.

Whoever has looked at a caterpillar, and then at the chrysalis or pupa, hair-less, legless, quiescent, and then at the winged imago, can easily believe that the tissues have undergone great alteration; but while some structures disappear entirely and others come into existence, the reproductive glands are present from the beginning. They can be tracca from one end of the line of development to the other;

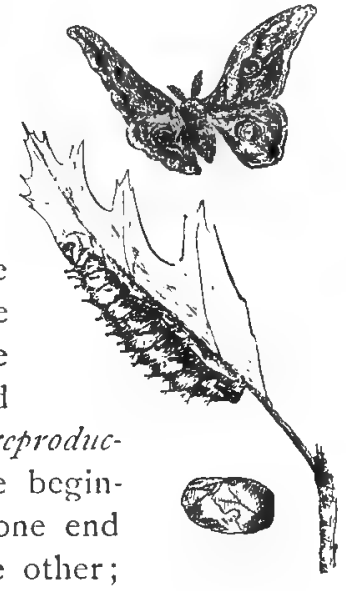
in the larva they may be seen, and through the pupa they persist to mature in the imago.

This egg material, like the amoeba, seems to have great power to live.

The whole life of the insect appears to be one vast, complex, stupendous preparation, whose end is love. 
Wonderful instruments are furnished it, that it may successfully perpetuate its kind.

Like its cousin the lobster, the insect, in its

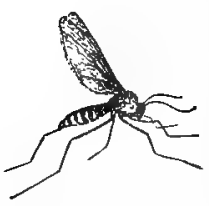
inago or perfect state has a body, the latter part of which is composed of rings. There are ten or eleven of these rings, the oncs toward the head being very like each other, but toward the tail end there is a marked alteration in

size and form.

The last three or four segments or rings are usually very much reduced in size, particularly on the under side, thus causing the end of the body to curve in.

These smaller segments give rise to certain long, slender growths on the under side, ultimately form. ing tubes, capable in some cases of being withdrawn into the body.

These terminal organs, in some species, are very complicated.

As in other creatures, the ovaries of the insect lie one on cach side of the inner cavity of the body, egg-tubes or oviducts leading from them to the outcr world. In the male, sperm-sacs and spermducts take the place of ovaries and oviducts.

The oviducts and sperm-ducts communicate at their outer opening with the elongated terminal organs, which, in fact, form tunnels through which the eggs and sperm-cells may be safely conductcd to any given point. 


\section{Reproduction of Insects.}

In the female, the long terminal organs form the ovipositor, or egg depositor.

By means of this the female is able to conduct the egg from the oviduct to a place suitable for its development. She does not merely drop her egg to find a lodging where it may, as the fish so often does, but by means of the long tubular ovipositor often places it in positions which without this instrument would be totally inaccessible.

The ovipositor assumes a great variety of forms in the different species.

Sometimes it is not a closed tube, but made of separate grooved blades, which fit together to form a tube when so needed. The blades may be toothed like a saw, may be tipped with a sting which connects with a poison sac, or may end in a sharp point or drill, for boring holes in hard substances; in short, may be modified in an incredible number of ways.

This ovipositor, this egg-conductor, is the female's priceless means of defence, and her implement for finding ingress into difficult, but for the offspring, desirable, places.

The saw-fly uses the toothed blades of the ovipositor to cut incisions in leaves and stems, where it then deposits the eggs.

The wound so made is, in some cases, accompanied by a secretion which irritates the plant tissue, so that it grows up about the egg in the form of a " gall," or little hollow chamber, in which the egg cosily develops. 5 
66

\section{Life and Love.}

The galls so often seen on trecs and bushes are the result of the intrusion under the skin of leaf or twig, of an egg or eggs, by some insect.

The gall-fly sometimes covers the leaves of the oak with the result of its industry. Thus, by means of its wonderful ovipositor, does one of the most delicate of the insect tribe compel the mighty oak to cradle its offspring.

Endless are the devices of insects to insure the welfare of offspring, which they will not live to behold.

What mysterious wisdom informs them concerning the food of their larvæ, food which they themselves no longer use, and leads them to place the egg in contact with that food, thus spreading the table of their offspring, enabling them to eat at once, and so gain strength to care further for themselves?

The Ichneumon fly has, in some cases, an enor. mously long ovipositor, which she inserts in crevices in the bark of trees, in order that she may deposit her eggs, not in the bark of the tree, but in the body of some unfortunate caterpillar which has there taken refuge! The caterpillar is thus compelled to render up its own life to form nourishment for its unwelcome and voracious guests. Insects are no better than fishes in their cannibalistic tendencies, onc species not hesitating to devour members of another species, or to feed its young at the expense of other insect life. 


\section{Reproduction of Insects.}

Certain wasps use the powerful weapon with which they are provided, to sting other insects, which are thereby paralyzed, and in this condition stored in the nests to feed young wasps. Thus is a store of living food laid up.

A caterpillar stung by a wasp will often transform into a chrysalis or pupa, though too weak to change to a moth, and thus feebly living will yield itself as food to its enemy.

Insects have no greater foes than each other. Constantly threatened by the sister life about them, as well as by innumerable other foes, the exorbitant fertility of the insect results, as a rule, in the maturing of but few offspring.

The ovipositor is the mother's greatest hope in insuring success to her offspring. By its help she can hide her eggs, supply provisions for them, or otherwise assist them to a position of advantage in the struggle for life upon which they must enter.

The grasshopper uses her large, strong ovipositor to bore holes in the ground, or in stems of plants, and into these holes the same hollow ovipositor conducts the eggs as they leave the oviduct.

The katydid uses the end of her ovipositor to shave off and roughen the bark of the twig upon which she lays her eggs, fastening them in place by a gummy substance which she exudes.

Thus do we find the egg-duct of the insect supplemented by a powerful auxiliary that pierces, or 
saws, or bores, or stings in the interest of the egg.

In the male the last segments of the body are also modified to assist in the important office assigned to him.

The outgrowths from the lower side of the hinder abdominal segments take the form of powerful intromittent organs, which are often furnished with complicated claspers to hold them in place while the sperm-cells are being conveyed, or " intromitted " to the oviduct, there to mingle with the eggcells before they leave the body of the female, and with a minimum of waste, secure life to the being imprisoned within the egg.

In many insects this transference takes place during flight.

Generally it is soon followed by the death of both male and female, the female living only long enough to wield that wonderful and complicated mechanism by which she is enabled to place her eggs in positions of advantage.

The ovipositor, like the wings, is the dowry of the imago. As a rule, the larva is devoid of this complicated mechanism in the female, and the equally complicated intromittent organ of the male. Only for the brief hours of its winged life do these complex structures come into existence.

Oftentimes the female is provicled with a receptacle for storing up the sperm-cells of the male.

This is the case with the bec, where only once 


\section{Reproduction of Insects.}

does the female receive from the male a supply of this essential material. Only once does he make the mysterious and fateful transference of his life to her. He gives all in this one act, then is doomed to death, while his germ-cells, nourished in some mysterious way by the female, live on, sometimes for incredible lengths of time, - even for years, and she, thus permanently supplied, fertilizes her eggs at will.

The domestic life of the bees is more or less familiar to every one. With them the queen is the most important member of the community. She is tenderly reared and sumptuously fed, and all her life long guarded and protected. Only once does she depart alone from the hive. The drone is the male bee, stingless and helpless. He, too, leaves the hive - once. Upon the return of the queen from her nuptial flight she is possessed of a store of sperm-cells, which she keeps in a little sac to use at her pleasure. The supply has been known to last for five years.

Unfertilized eggs develop into drones, those which have been fertilized become either workers or queens.

The hapless drone, when once his office has been fulfilled is not allowed to return to the nest. $\mathrm{He}$ is no longer necessary to the economy of the hive, he is but a tax upon the strength of the workers; ruthlessly they usurp the power which nature exercises in many of the other insects, and put him to death. 
His life culminates and ends in his power to reproduce his race. That is his only excuse for existing, his companions seem to think. Helpless, stingless, he is cared for by his hive-mates until he has provided life for future generations.

In her season of greatest activity the queen bee sometimes lays as many as two or three thousand eggs a day, and in the course of her life may lay more than a million; and this astounding number of eggs she is able to fertilize by that one gift from the drone!

On the surface it seems a harsh decree that takes from him his life in return for such inestimable service, but when one looks beyond the one drone into the great world of bees, striving for their place in nature's crowded courts, one loses sight of the individual and is borne along in sympathy for the wholc beautiful race, struggling to insure its continucd existence, it may be for somc final end, some development undreamed of by the man of to-day.

Unlike the butterfly, the bee is not exhausted beyond recovery by the labor of maternity, in part perhaps because her hive-mates have kept her so bountifully nourished from the very beginning, and continue to supply her with the nutriment which will most quickly repair her loss.

Her obligation in life is to reproduce; the workers, which are practically sexless, have no obligation but to care for their teeming queen and 


\section{Reproduction of Insicts.}

for the young with which she replenishes their ranks.

They supply the food, build the nests, rear the young; they know life, but not love. They live not more than eight months, then die, their places filled by those nurslings they have not mothered, but faithfully have tended.

Protected and cared for, the queen bee lives longer than most other adult insects. Even her amazing fertility does not exhaust her beyond repair.

Where other insects are prevented from losing the vitality contained in their reproductive material they, too, have been known to live beyond the ordinary limits of their kind. In one instance a butterfly was thus kept for over two years in a hothouse, when in the natural order of life he would have expended his reproductive force, and his race would have been run in a few short days.

Quite at the mercy of their surroundings, the insects do not, as a rule, attempt individual preservation; the individual is allowed to perish, the whole effort being towards preserving the race by supplying material for new generations.

Even the wings of some species are but neans to this end. It is said that after the nuptial flight ants bite off their own wings! They have no further use for them, and they are but an incumbrance; their lives henceforth must be concentrated upon securing offspring to succeed them. 
In some insects only the male is winged; the female quicscent, attractive, waits to be approached.

As a rule the female among insects is larger than the malc, and in some low forms of insect life the male is reduced to a tiny parasite upon the large and well-nourished female.

Brief as are the adult lives of the insects, it may bc, that measured by their intensity rather than by their duration, they sum up as much that makes for life as the more extended and less intensely vital lives of other creatures. In their brief existence they find time for the more esthetic pleasures, and the joys of courtship are one of their possessions.

It would seem, according to Darwin, that their love of color influences their selection of a mate, the female in some species yielding to the charms of a brilliant suitor, and scorning the advances of a dull one.

Thus, through her individual taste, does she in her selection of a mate give a brilliant inheritance to her descendants, and people the earth with those animated emcralds and rubics and bits of flame with which every one is familiar.

Any one interested in the lowcr life and its wonderful manifestations can by watching the grasshoppers on a summer day witness many amusing love-scenes. My lady understands her importance in the economy of nature, apparently, and also enjoys the suspense of her lovers. 
She is both coy and inviting, and the males practise their most alluring arts, flying and wheeling and whirring, and chirping for her edification in the hope of finally proving irresistible.

The female spider is, perhaps, the being most powerfully imbued with a sense of feminine importance.

In some instances the male, small, wary, timid, in mortal terror, as well he may be, of his fierce ladylove, loyal to his race, hands her, on his palpi, or movable mouth-parts, his store of sperm-cells, and she snatches the precious gift, and then longing for still closer union with her beloved also snatches him, if he is not quick enough to escape, and

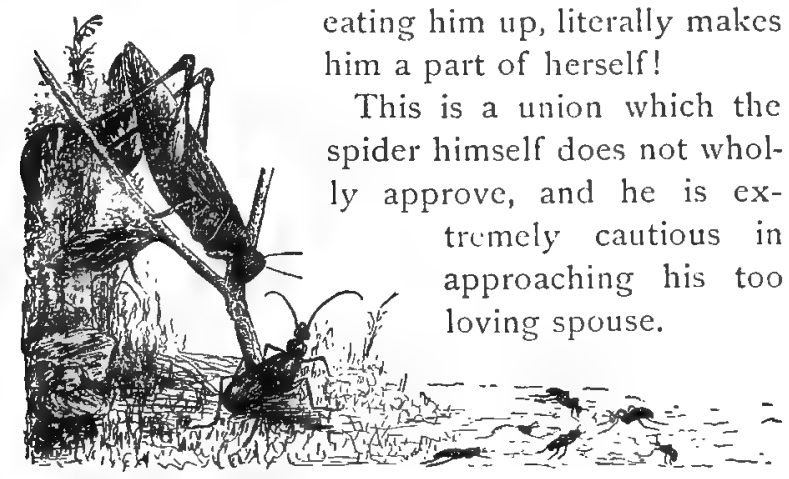




\section{IX.}

FLOWERS AND INSECTS.

CLOSELY intertwined with the life of the insect is that of the flower, and in many respects

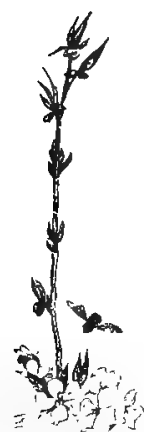

(is

.
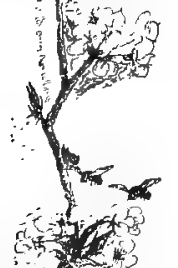

$+x+\frac{1}{2}$

$x+2$

表

there is quite a remarkable similarity between the two.

Justice could not be done to the great cycle of Life and Love without taking into consideration the blooming of plants, which is the imago or butterfly state of their existence.

The plant, like the animal, is dependent upon food for its existence; also, like it, upon air, moisture, warmth, and for its continued existence, upon reproduction. The plant is the real arbiter of life. It is the link between the inanimate and the animate worlds. Standing upon the very brink of existence, it converts inorganic matter into living material, and on the other hand finds itself vitally connected with animal life.

It retains the primal and unique power of transforming mineral matter into living tissue. Place it in watcr containing in solution the 


\section{Flowers and Insects.}

elements it needs, - nitrates, potash, lime, magnesia, silica, or what not, - and it will grow as merrily as though standing root-deep in the earth. Contentedly it will fall upon these intractable, lifeless substances, and persuade them to combine in ways new to their habit, until they find themselves no longer cold mineral elements or compounds, but a vital combination, with new and wonderful powers. These tissues, formed thus from the rocks and gases, are the reliance of the animal for subsistence, so that all or nearly all animal life is sustained by this vast store of food made ready by plant life.

To a very limited extent only can the animal convert minerals and gases into living tissue; that power it has lost, and relies upon the vegetable world to stand between it and annihilation.

The vegetable world is the benign providence, the never-failing nurse of the animal world. And all the life of the animal world it shares. It is born, waxes, wanes, reproduces, dies.

In spirogyra we saw the dawning of love in the life of the plant, and higher in the vegetable world we find life depending upon the union of two.

Like the animal, the plant passes through all stages of complexity in its reproductive life.

Here as elsewhere reproduction is but a budding off of a portion of the parent, - a discreet budding of such a cell or cells as in some mysterious way bears the impress of the whole personality of the plant. 
In the vegetable, as in the animal world, all degrees of complexity are observable in the method of reproduction.

The fern, for instance, as a part of its reproductive activity, employs the primitive method of casting off buds from the skin; from the under side of the leaf, as a rule, it gives forth tiny spores in countless numbers. These spores are enclosed in cases symmetrically arranged in groups, sometimes along the margin of the leaf, sometimes along the central rib, sometimes thickly clustered over other parts of the surface.

The leaf so given up to spore-bearing is frequently different from the other leaves, being smaller, thicker, duller. It is the old story; its nutrition having gone to the making of spores, there is little left for the leaf itself.

Every one knows the fern in its spore-bearing state, its fronds heavily laden with the dark-brown or black or other colored patches of spores or "dust."

These spores are necessary to the reproduction of the plant, but are not true seed, for those are the product of a higher form of plant life.

The ferns, the mosses, and all the flowerless plants belong to the lower ranks of plant life; they are the jelly-fishes and sea-squirts, as it were, of the vegetable world, and have a complicated reproductive method, of which the spore-bcaring stage is but a part. 
The flowering plant corresponds to the higher animals; its reproductive material is enclosed and cherished; its seeds and sperm-cells develop under delicate protecting wrappings, and are not exposed as are the unprotected fern-spores.

And all this care of the seeds and forming of them, is accomplished in the cleverest way by the plant, no distinctly new tissues being elaborated for this important office.

It was Goethe, the poet, who first established the flower-leaf identity, and now every one knows the beautiful and poetic truth that flowers are only modified - why not say glorified? - leaves.

Nature has a way of her own of economizing material, and has exercised a delightful ingenuity in the uses to which she has put her leaves, sometimes compressing them into thorns or scales, again expanding them into petals, or rolling them into pistils and stamens.

Originally composed of but stem and leaf, the plant successfully achieves all of its wonderful organs from the manipulation of these two primitive parts.

Rising through rank upon rank of green leaves the lily ends in a burst of poetry. The green leaves are transformed by love, - the pupa becomes the imago.

Instead of continuing to produce scattered leaves along a lengthening stalk, the leaf material is congregated together in close ranks, some spirit of 
beauty rests upon it and refines and glorifies, so there unfolds in splendor the broad banners of snowy white, of glowing gold or crimson.

Nor is this all, - nor the prime cause of the transformation.

The gorgeous wings of this imago are but the outbreak of the love that animates it, and surrounded and protected by the shining robe are other leaves yet more curiously modified, and on whose account all this beauty exists.

Standing within the bright petals are yet more delicate leaf transformations; these are the stamens composed of filaments, tipped with anthers,

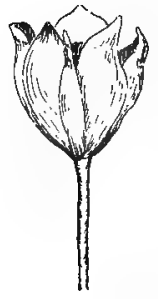

- each anther a tiny box, as though the blade of a very little leaf had been rolled in at its edges and fastened there. And this box, this anther, contains the pollen or "dust" of the flowers, which one suspects to be matter of importance, placed thus in the heart of the flower, and formed thus centrally from metamorphosed leaves. The suspicion is well founded, for in this dust we recognize the "sperm" of the plant, — these tiny pollen grains being the small male cells. True to their kind, they are small, active,

ff: variously shaped in different plants, - and true to their nature, they have not power to develop alone.

They contain, as we may say, but half the power of life. The other half is safely folded within yet 


\section{Flowers and Insects.}

another set of metamorphosed leaves. Look again in the heart of the lily.

Here we see a central column, firm, strong, and large, as compared with the delicate stamens. This column is formed of altered leaves, folded-in in such way as to convert its swollen base into a number of closed chambers; and as the pollen was budded from the inner part of the transformed anther-leaf, and the spores from the surface of the fern-leaf, so are the little ovules or seedlets, as shown in the diagram, which represents a cross-section of

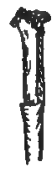
the ovary, budded from the inner side of these curled-up ovary leaves.

Yes, this closed chamber is the ovary.

In it lie the seed-cells, or, as they truly are, the egg-cells, unable without assistance to develop into a new plant. It is but the story of life told over again.

The pollen ripens, the anthers open to let it escape, and it falls upon the stigma, or broad upper end of the column leading to the ovary. This column is practically hollow, and through it the pollen grain reaches down to bestow its life-insuring touch upon the ovule. Falling upon the stigma, the pollen grain, absorbing speedily the nutriment about it, grows rapidly, reaching down a slender, finger-like tube, which finds its way straight to the opening in the ovary, and powerfully attracted by the waiting ovules, joins one of them, transferring 
its tiny atom of protoplasm to the contents of the ovule, just as the protoplasmic material of the sperm-cell joined, and was fused with, the egg-cell.

Life is all one. There is no great difference between an animal and a plant, - merely a difference of degree, rather than of kind. Springing from the same source, one form of life moves rhythmically on for but a short distance, then reaches the end of its ancestral path, - another moves yet farther along a more difficult way; yet are they brothers all, and inextricably joined the one to the other along the whole line of life.

Animal could not live without plant, plant could not live without animal. The carbonic acid gas exhaled by all animal life forms necessary food for the plant, and this carbonic acid gas, were it not appropriated and cleared from the air, would suffocate the animal in the product of its own activity. At the same time the animal depends upon the plant to liberate oxygen for his consumption.

But nowhere are plant life and animal life more curiously and intimately connected than among insects and flowers.

The same laws that govern animal reproduction govern plant life.

When the period of fertility approaches we find the plant tissues undergoing a change; certain of them burst forth in rare bloom, and this gorgeous coloring, we are told, is developed to such intensity because of the lore of insects for bright colors. 
The flower is the result of changed leaves, - the changes which thus tranform the hard green leaf to the delicate white or pink or blue petal, recalling the phenomenal reproductive changes in the animal life.

The initial power to change resides in the plant or animal. When, through this tendency to vary, a new form of life arises, the conditions into which it is finally born determine whether it shall survive or perish. For instance, suppose a certain kind of insect be born sometimes green in color, sometimes brown. Suppose too, that these insects live upon green leaves, and are agrecable to the taste of certain birds. The brown insects would be more quickly detected and would be eaten, the green ones surviving to reproduce their kind, and hand down as an inheritance the tendency to be green. Thus, in time, there might arise a race of insects always yreen. Thus the conditions under which they lived would determine the color of the race.

In the same way any variation in the animal or plant which better adapts it to the world into which it is born, through inheritance tends to become fixed; and any variation which puts the living thing at a disadvantage to its surroundings is quickly eliminated by the death without offspring of the form so unfortunately endowed. In time of hardship the cattle or deer best able to obtain food and to resist cold, through superior intelligence, or 
hardihood, or better developed hoofs or horns, or some advantage in size or shape or coloring, survive to hand down these characteristics to their descendants.

Thus the animal is to an extent dependent upon its surroundings for its form, - those best adapted to their surroundings crowding out of the life struggle those less well adapted This is what Darwin calls natural selection, and I Iuxley the survival of the fittest, and is as operative in plants as in animals. Any development of plant life which better enables it to live and get nourishment gives it an advantage over its less wcll endowed companions, so that its seeds are more likcly to mature and grow.

The initial power to change, then, resides in the plant; this power to vary expressing itself in many ways, natural selection finally determines which of the forms shall become permanent, - and natural selection in this case is often insect selection.

In order to understand this, let us recall the fact that too close relationship between reproducing individuals is no more desirable for many plants than for animals, and in the course of ages many flowers have become so formed or modified as to render self-fertilization impossible. The flower has evolved the most curious and ingenious devices imaginable to this end.

Sometimes stamens and pistil mature at different times, so that when one is ripe the other is not, 


\section{Flowers and Insects.}

and there can be no fertilization of one by the other, or else one has already passed its period of fertility and is no longer active.

Again, stamens and pistil are sometimes so related to each other that the pollen cannot reach the stigma unaided.

Oftentimes, too, the pollen is inoperative in its own flower, even acting as a blight.

Sometimes the pistil curves away from the stamens, sometimes, it shuts itself up in a little box of petals and refuses to look forth and receive the gift of pollen from its own stamens.

What madness is this on the part of the flowers?

The pollen cannot, as a rule, like the sperm-cells of the fish, float about until it find its companionlife. Although ready enough to grow down into the ovary when once it finds lodgment upon the stigma, the pollen has no wings to bear it from flower to flower, no legs to enable it to search for its companion-life - then what does this refusal on the part of the flowers mean?

Ah, but the pollen has wings, and there is in the flower a confidence born of long ancestral experience that these wings will appear in time and bear its pollen to waiting ovules, as well as bring to it fresh pollen from neighboring plants. The wings are those of the insects. Long ages of this sort of interchange have formed flowers dependent upon insects for fertilization. The bee enters a blossom 
whose anthers are ripe but whose pistil is trustingly immature, - not desiring its own pollen, and not fearing failure if it decline to receive it. Probing deep for sweets the bee plentifully dusts her hairy form with countless pollen grains and flies to another flower of the same species for increase of honey store, and there, it may be, comes upon a blossom whose stigma is ready, but whose anthers are not, and in again scarcling for sweets transfers pollen grains to the ready pistil.

As many insects visit each flowcr every day, and as the insect generally gocs from one flower to another of the same kind when convenient, apparently not liking to mix sweets, it follows that all the flowers have ample opportunity to get pollen from another plant when the time comes.

Some flowers have such faith in their winged friends that they have taken forms which make fertilization, except by certain insects, impossible.

Some orchids prefer moths as bearers of their love messages, and we are told that only by the eycs of the moth, as it thrusts its head into the flower-cup, can the pollen, adhering in long adhesive masses, be conveyed from these to neighboring orchid flowers. The red clover closes heart and petals to all but the bumble-bee. She alone can gather red-clover swcets and carry pollen to its ovules.

Fascinating as any romance is the story of the loves of the flowers and their marvellous devices 
for alluring certain kinds of insects and electing them as bearers of love messages to other flowers.

Fascinating too is the story of the creation of flower-forms by insects.

We are told by one whose life was devoted to reading nature's story that the flower whose color, whose odor, whose nectar attract is constantly visited by winged creatures whose presence results in the sure transference of pollen to waiting stigmas, and consequently there results maturing of seed and assurance of the continued existence of the plant; while another flower whose activity expresses itself in form or odor or color or nectar not attractive to the winged world must wait in vain for rejuvenescence and die at last unable to perfect seed for the continuance of its life.

Some insects are attracted by bright colors, some by odors. Hence those flowers having the brightest petals to guide the winged epicure to the honey it loves would receive most visits, would be well fertilized in consequence, and would have a better chance to mature hardy seed, and so hand on the color inheritance, than would less brilliant flowers.

Flowers exhaling the most powerful perfume frequently attract night-flying insects, and the color most readily seen at night probably being white, it is believed that the whitest and most highly perfumed flowers have been most favored by pollen- 
bearing guests, and so have tended to displace less well-endowed flowers.

Since color is enough to guide the insect in the daylight, it often happens that the most brilliant flowers are scentless. Honey and color being necessary to attract the bce, the flowers containing those two properties were doubtless most frequently visited, the less bright or less well supplied with honey being overlooked and left unfertilized or obliged to resort to self-fertilization, which, resulting in feebler seeds, gave the advantage to the insect-fertilized flowers.

White flowers, on the other hand, are quite universally fragrant-for obvious reasons.

Any peculiarity of form or structure which could give the flower an advantage in being fertilized would result in the development of its seeds at the expense of the less hardy seeds of less fortunately constituted plants, and so in time there might arise, as undoubtedly there have arisen, many wonderful and beautiful flower-forms.

Insects, then, have been instrumental in producing color, odor, and form in flowers, and are necessary to the existence of many forms of plant life.

The hum of countless insects about the blossoming fruit-trec is not only a soothing and delicate sound in itself, but conveys a pleasing sense of security concerning another season when masses of bloom shall be succeeded by a rich harvest of fruit. 
That bees and butterflies love the same colors and odors that man loves is one of the beautiful harmonies of nature; through this refined taste in the world that moves on gossamer wings has come to man much of the great beauty of the flower world and its intoxicating odors.

Inextricably and beautifully is all life intermingled.

Insect and flower, - - one in beauty and in nature; each contributing to the happiness and the fulness of life of the other, and to the fulness and life of man.

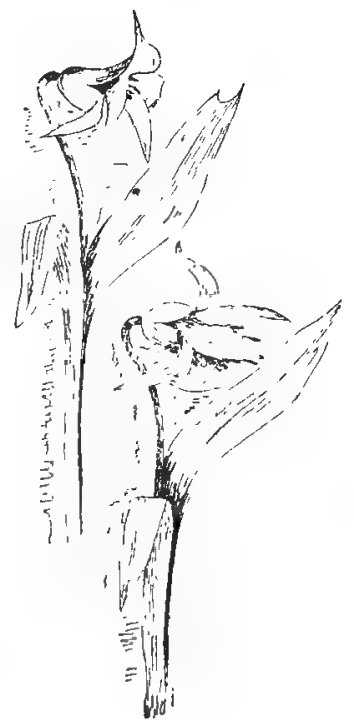




\section{$\mathrm{X}$.}

PLANT LIFE.

NeCESSARILY there is a great waste of reproductive material among the plants, particularly of the pollen, and this again recalls certain curious facts of the lower animal life. Much pollen is entirely lost, as it probably takes but one pollen grain to fertilize each ovule; but a million grains may not be too many to make certain the finding of the ovule by one. The insect is a sure messenger where therc is abundance of material; sooncr or later the result of fertilization will be accomplished by it, but it might happen that many visits would be made before pollen was successfully transferred to waiting stigma.

The bec, for instance, not only fails sometimes to hurry from one plant to another of the same lind, but is not consciously working for the plant at all. Her con- 


\section{Plant Life.}

cern is herself; she desires honey for her own use, and also puts the pollen to a use not at all designed by the flower; she stores it away in the form of "bee-bread" as food for herself.

But the plant can well afford a generous largess of even the precious reproductive material to those active winged helpers, and as a rule the number of pollen grains produced by a single flower is something almost inconceivable.

They, like other sperm-cells, are very small, sometimes microscopic in size, and oftentimes of very beautiful and remarkable forms. To be able to look into the world which the microscope reveals is like being endowed with a new and fincr existence, it so enlarges one's mental horizon.

Some plants are so prodigal of pollen that they do not depend upon insects as pollen carriers, but by an astounding fertilty fill the air with this precious "dust," so that it is literally borne upon the wings of the wind from one flower to another. Certain trees have this habit and the number of pollen grains they consign to the transportation of the wind is beyond man's power of comprehension.

Sometimes for miles clouds of pollen will be carried, covering the ponds with a light film and filling the air. Sometimes this pollen dust is caught in a storm and carried into upper air-currents, where it is borne along over vast distances, finally falling in a cloud over a distant region, sometimes 
producing curious effects known as "yellow days" or "red days."

Fortunately, the presence of the wrong pollen has no effect upon the flower; otherwise the stray grains from all sorts of plants borne by wind and insect would produce such confusion in the vegetable world by fertilizing lilies with roses, or poppies with morning-glories, that nothing would be able to keep its own form. Nearly related plants can sometimes fertilize one another, however, and if the farmer wants good melons he must be careful not to let pumpkins or cucumbers grow near the melon-patch; otherwise the busy bees going from pumpkin to melon may fertilize the melon with pumpkin pollen and the result be a sort of pumpkin-melon not at all agreeable to the taste.

As is the case with some insects, the plant often grows and stores up nutriment for a time, finally to expend the whole stock so accumulated in one vast effort of reproduction.

Plants with succulent roots, as radishes, turnips, carrots, and beets have this habit. Sometimes one whole growing season is devoted to storing up a great root full of starch and other foods; then winter comcs, and the plant dies above ground, but lives below. Next season the beet or turnip sends up leaves and flower-stalk with remarkable speed. The growth is luxurious and prodigious, and abundant bloom is followed by the maturing of many seeds. 
Look now at the root under ground; it is. no longer plump and full of nutriment, it is shrivelled, tough, and fibrous, no longer fit food for man; its great store of nutriment has been consumed by its effort at reproduction. It reminds us of the pupa, lying inert and full of nutriment, only to transform its accumulated store of food into the beautiful imago.

Like the butterfly, the plant reaches its imago state; it blossoms, bears seed, and dies.

The sisal hemp spends ten years elaborating leaves of great size and thickness, until it resembles a monster century-plant; then, forsooth, out springs a great flower-stalk from its very heart; this flower-stalk, as thick as a man's arm and twenty feet high, topped with a great crown of bloom, grows in the incredible time of six months! As might be expected, this mighty effort is followed by the death of the plant.

If prevented from blossoming it will continue to grow, and may reach prodigious size. This, too, is true of other plants.

Prevent the reproductive sonsummation, and the plant, instead of running its little cycle of growth, reproduction, death, will live on.

Saved from the tremendous changes and loss which accompany the reproductive function even in plants, they continue to perform their vegetative acts for a longer period.

.Fruit-trees which bear too young exhaust them- 
selves and fail to make a satisfactory growth of wood; so the careful gardener removes the flower buds from his young trees.

The great majority of plants have a short period of growth, followed by reproduction and death.

This is not true of all, however; some, like the higher animals, having recurring seasons of reproductive activity, followed by rest, instead of expending all in one great effort.

Some, as has been seen, grow for several seasons in preparation for one glorious outburst of love and beauty, after which their race is run.

To the short-lived plants belong many of the garden flowers. They come from the secd in the spring, and in the fall fade never to revive, - their life preserved in the seed thcy perfect.

The wild flowers that make the woods dear to us in the spring are exquisite love-songs, and only that. The hepatica, the spring beauty, the dainty dicentra, are Nature's glad tribute to the great love that alone keeps the earth sweet and desirable. They blossom in an hour as it were. Underground live stout roots and compact bulbs, reservoirs of nutriment, to enable the delicate stems and leaves to go forth and blossom and scatter seed for other beautiful spring-times.

If it were not for love there would be no flowers. If it were not for love there would be no beauty on the earth. 


\section{Plant Life.}

The trees take life less tragically than do most of the garden flowers. They grow at their leisure, and after years of careful preparation bloom with temperance, and unexhausted live on to repeat each year their anthem of love.

The peach-tree, growing rapidly and hastening into rapturous outbreak of ecstatic pink, pays the penalty of too great ardor by soon closing its career.

The apple-tree, less vehement, grows more leisurely and waits longer for the consummation of love to express itself in a fragrant mantle of bloom, and consequently has a longer lease of life; while the orange-tree, yet more discreet, lingers in preparation for eight or even ten years, then applies itself to the creation of fragrance and beauty for a correspondingly great length of time, increasing in power each year.

Early maturity thus seems, even in the plant world, to be connected with early death.

The blossoming of a plant is always an expression of its desire to reproduce itself.

The flower is the symbol of love; within it is somewhere concealed the ovary with its burden of waiting life, or the stamen with its burden of eager life.

Often one flower contains both ovary and stamens, though very frequently this is not the case. As in the animal life, the ovary is sometimes in one individual, the fertilizing material in 
another; in this case the continuance of life in the plant is entirely dependent upon the kindly offict of wind or insect.

Even where both kinds of reproductive material are in one flower, as has been seen, their union is not desirable, and precautions are often taken to prevent it.

The mountain laurel has its immature stamens bent over like springs, the anthers concealed in little pockets along the inner side of its white cup. The brecze, the wing of a bird, the jostle of a passing creature stirs the laurel-bush, and out fly these delicate springs, throwing the pollen with force enough to land it quite to the other side of the bush, or upon a neighboring bush. Of course this is precarious, for it may not land upon a flower at all; still, with these assaults of pollen continually going on through many summer days, each flower will have a chance sooner or later to secure the prize. One cannot doubt this when observing the seed pods that later weigh down the laurelbushes.

The fruit, so agreeable to the palate of man and to the birds, is but a development of the ovary or some related part, and is not the first thought of the plant. The apple exists, not for the pulp, juicy and delectable to man, but for the black little secds concealed within the pulp.

The delicious envelope of the plum, peach, pear, apricot, are but invitations to the sister life in the 


\section{Plant Life.}

animal world to cat and convey away unharmed the seed within, to new fields for its development.

The berries entice that good may come to them.

The tiny seeds though swallowed will not digest, they are but carried to other places, where they may chance upon suitable soil for growth.

"Eat this sweet pulp and cast away my seed into new and fertile soil," the apple seems to say, while the burr, the beggar's lice, the stick-tight, cover their dear seeds with hooked mantles that cling fast to passers-by, and thus scatter the seed over new fields.

What applies to the animal life, in a general way applies to the plant.

Prevent the loss of the reproductive material, and life can be prolonged; to an extent even the evanescent flower can be preserved by preventing it from fulfilling its desire.

Remove the anthers before they open from the tall white lily, and the regal flower will not fade so soon by several hours. Its activity is arrested, it does not precipitate its whole life upon the perfecting of seed, - it waits. Finally it fades, slowly and lingeringly, as loath to leave unaccomplished that high end for which it unfolded its beautiful form.

Its glorious vestment, like the wings of the butterfly, adorn it only for the season of love; the 
high office of love once fulfilled, the petals fade and fall, the empty stamens too fall away, and there is left of the flowers only the ovary to go on growing until the seeds are perfected.

Since petals and stamens and pistils are but transformed leaves, one is not surprised to find all stages of transformation observable in some flowers. In the water-lily can often be seen all stages of stamen forming, from the perfect anther with its filament, to the petal tipped with a half-formed anther. All double flowers are so at the expense of the essential organs, as stamens and pistil very justly are called. An extra row of petals means one row the luss of stamens. A double rose sometimes has all the stamens and even the pistils converted into petals. As a rule, double flowers are the result of cultivation, the plant depending upon man for such care that it shall be preserved, and not troubling to form the reproductive cells and enclose them in protecting walls.

The tall, spotted lily, however, so familiar in old gardens, cannot trust its reproduction wholly to seeds, but in the angle of each leaf gives off little round black bulbs which are tiny reproductions of the parent plant.

These little bulbs, reminding us of the sprouting of those worms that do not wait for the eggdevelopment, fall off, and in time may grow, having impressed upon them in some mysterious way the wholc personality of the parent plant. 


\section{Plant Life.}

Thus again we see how reproduction is everywhere the same, but a budding off of a portion of the parent, which under suitable conditions may develop into another being like the parent.
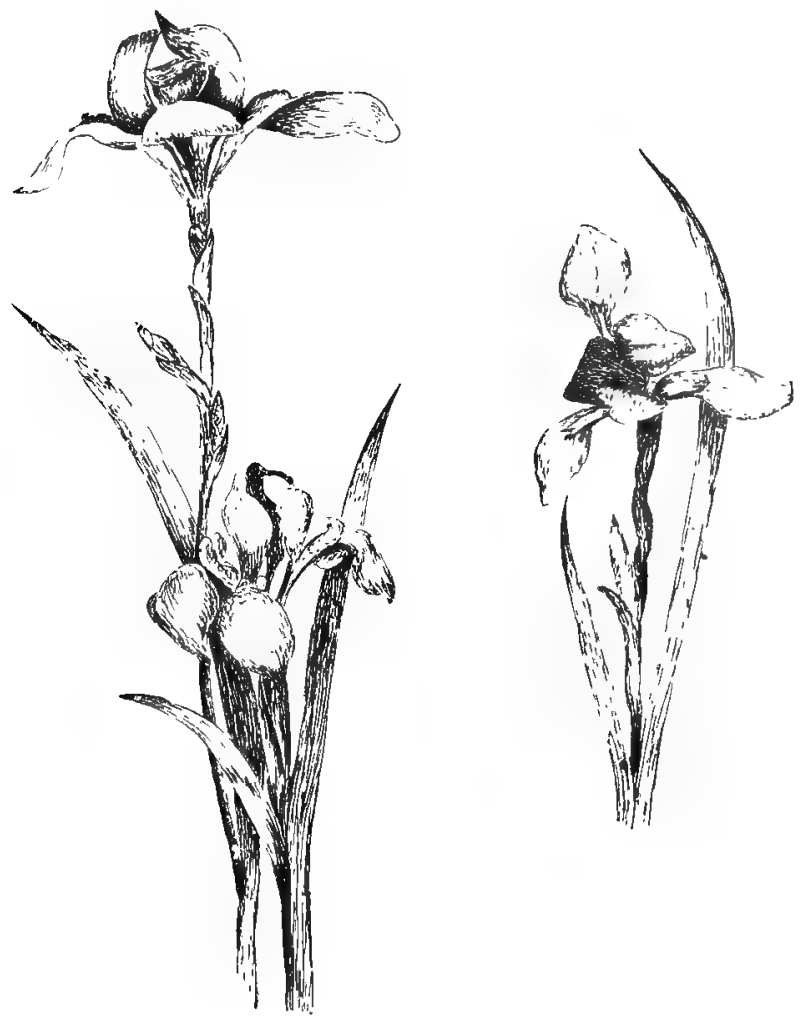


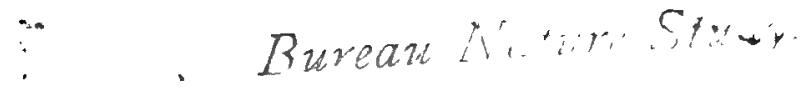

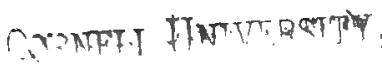

\section{BIRD LIFE.}

A $\mathrm{S}$ the life ascends, - that is, grows more complex, - the creature is less prodigal of the

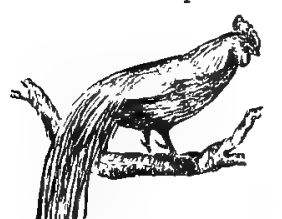
reproductive material.

The demands made upon the higher and more complex orders are so varied, so great and costly, that the tremendous fecundity of the lower life cannot be maintained; so in these the germcells are less exposed to the possibility of destruction.

A bird which lays but a dozen eggs in a season cannot exhibit the stupendous indifference to results that characterizes the fish which lays a million or more.

The love-life of the bird is very active, however; it is an intermittent condition instead of a single cataclysm, and so, culminating less exhaustively, continues for a longer period.

As the breeding scason approaches, the male bird gives evidence of the greatest exuberance of vitality. He often 
fights in a desperate manner, he yet more frequently sings out his emotion, and his plumage appears more alive than at other times.

The feathers are glossier and take on a new iridescence, even among the black or brown varieties.

The female, usually quiet in coloring, assumes a glossier appearance at this time.

The young birds, male and female, resemble the mother instead of the father in the color of their plumage. But as the young male approaches maturity, as the life-germs develop toward completion, a change comes over him.

The vitality that accompanies the unfolding of these marvellous germs of life thrills through his whole body. His form quivers with a, to him, hitherto unknown emotion. If he be an oriole, behold the glory of orange and gold that burns in his feathers!

If a bird of paradise, he comes forth in long and brilliant plumes, like some strange flower suddenly blossoming in magnificence. The peacock spreads a fan gorgeous to behold. The scarlet tanager appears like a flame among the bushes.

Here is a bird as blue as the sky, there one the color of gold. Here again appears one wearing great spurs as a badge of his masculinity; wattles adorn him, and a comb red and haughty.

Tufts of feathers, graceful aigrets, and long plumes are the badges of many others.

In strange forms and stranger colors does this 
exuberant life of the male cxpress itself, and at each recurring season of love these badges of love and life are renewed.

Sometimes they but brighten, again they grow anew each season, disappearing when the brief turmoil is over.

And what care for the precious life-germs is shown in the listory of the birds! Here is no lavish expenditure, no pouring out of the principle of life to meet its fate exposed and disregarded.

The bird's ovarics are small, and placed deep in the innermost recesses of the body. There are two of them, one on either side, though as a rule only the one lying on the left side develops; so it seems in the adult bird as though there were but one ovary.

In this ovary the tiny egg-cells, no larger than pin-heads, form. A long tube, or oviduct, connects the ovary with the lower end of the intestine, whence it opens into the outer world.

Like the ovaries of the female, the sperm-sacs of the male are small and deep-hidden and have their outlet.

While still in the ovary the tiny egg-cell, as it ripens, absorbs a large quantity of food, so that it assumes in the hen's egg a size of about an inch in diameter, forming what we know as the yolk of the egr. When it has reached its full size the egg-cell breaks away from its containing membrane and begins its journey down the oviduct. 


\section{Bird Life.}

In the diagram are shown a number of eggs of different sizes in the ovary, $a$ being one ready to start upon its course to the outer world. Sometimes in the ovary, sometimes after it has entered the oviduct, the eggcell meets the sperm-cell, which has travelled all this way to meet it.

For this egg is not to suffer chance of destruction, like the egg of the fish that, rolled about by the waves, may miss the indispensable union with the sperm-cell.

On the contrary, the bird employs the method of the insect to solve this difficulty, and the sperm is deposited by the male within the duct of the female. It is true the bird has no complicated intromittent organ as has the insect, yet there is sufficient modification of structure at the outer end of the tube through which the fertilizing fluid is to

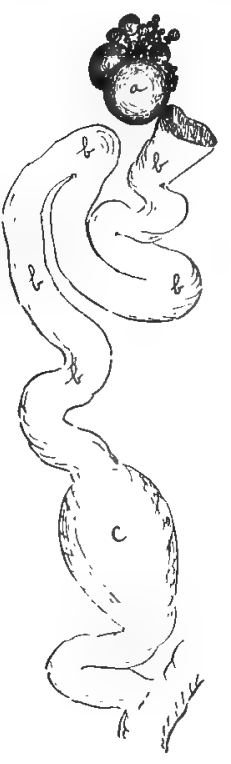
pass to permit the desired result, and sperm and egg-cell meet before the latter has entered the world.

In this asylum, safe from harm, the sperm-cell seeks the egg-cell, often travelling as far as the ovary itself to find it, when it enters and is combined with it.

The now fertilized egg-cell moves along the oviduct, whose walls secrete for it a quantity of 
albumen, which we know as the "white" of the egg. As it moves along, the muscles of the oviduct give it a spiral motion, and thus turning around and around it becomes coated with the elongated "white," or albumen; $b$ in the diagram marks the part of the oviduct where it receives the albumen.

Next it enters the part $c$ where the lining of the oviduct secretes a limy substance which forms about it a wall, familiar to all as the egg-shell.

Thus nourished and protected, the egg is laid, a hard, firm, resisting, vaulted chamber, whose form no architcct could strengthen, so well are its arches planned to sustain weight and resist pressure.

The egg is laid, but the labor of love is not ended. In the bird, sex-life is but part of its reproductive history; parental love wakens to cherish these helpless imprisoned beings.

Oftentimes both parents feel an irresistible undefined attraction for the life to emerge from those marble walls. They look upon its prison and know that their offspring cannot yet come to perfection without their loving aid. So upon the hard cggs the parents sit, relieving each other; or, where this is not the case, the mother devotes hersclf unsparingly to forward the interests of the future life contained in them.

A stupendous task it is, and a cruel one, this compulsory, wearisome sitting upon the insensate eggs, by a creature to whom motion is joy itself. 


\section{Bird Life.}

Yet this, one or both parents joyfully do. More than this, some strange sympathetic knowledge of what is about to ensue causes them in most cases to prepare a home for the young before the eggs are laid. Skilfully they weave their cunning nests, and artfully hide them in grass or bush, swing them from the twigs of trees, or firmly plant them in their crotches.

Nor is their duty ended when the young come forth; then the cramped and tired parents stretch their wings, indeed, for these helpless ones must be fed. All day longr they fly abroad, bringing home dainty morsels, scarcely stopping to satisfy their own hunger, so urgent is the appeal of those hungry little ones.

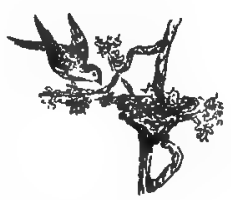

Now the plumage of the parents fades again, the male sings less exaltedly, the great quickening season of sex-life is over. The magic power that drew one to the other is in abeyance; cach has fulfilled this phase of its destiny; the one has laid the eggs, the other contributed to their development.

The first ardor of the love season having passed, in its place comes this new sympathy which makes them labor for the fruit of their great love, which holds them together in mutual work and weariness, and mutual love and joy in their treasures.

It is the dawning of a higher life. Parental love is an early and potent form of unselfishness.

Bcsides the instinct of nest-building and the 
feeling of parental love, the bird is subject, as has been seen, to many physical changes during the period of reproductive activity. Not only does it express its new activity in color and song; other curious changes sometimes occur, as, for instance, where in certain swallow-like birds the saliva-cells enormously develop and there is exuded a sticky substance which is made into nests for the young, reminding us of the strange glue by which the lobster holds her treasures to herself.

These nests, alas, are sweet to the palate of their human neighbor the Chinaman, and many a poor bird's labor ends in a too costly soup for his oriental highness.

Doves and some other birds during the breeding season produce a substance in the crop which softens the food and turns it to a thick, milky paste; this is regurgitated and fed to the young.

One old parrot, who was destined to drag out a miscrable existence in the zoölogical garden of a Northern city, relieved his overcharged parental feclings by achieving this result and feeding a similar food to his companions in bondage!

The bird loses but a comparatively small amount of reproductive material; it cares for its offspring both before and after their development, nucessitating but comparatively little waste of material, and we find it less cxhausted by the function of reproduction than are many of the fishes.

In it the powir of life is not immediately lost; 


\section{Bird Life. $\quad 105$}

again and again will it waken to renewal as the earth breaks out in its spring-tide of new life; again and again will the birds hear the ecstatic sounds of love ring through nature's courts, and feel the thrill of life and love in their own hearts. 


\section{XII.}

\section{SKIN CHANGES.}

T $\mathrm{N}$ young animals the male and female are as a 1 rule very similar to each other in appcarance

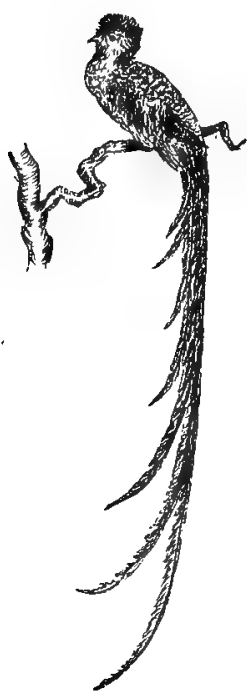
and disposition. But as they near maturity a change takes place, and they begin to diverge from each other, the male acquiring peculiarly masculine, the female peculiarly feminine characteristics. The maturing of the reproductive cells is in some deep way connected with profound changes in the whole being, and these changes affect the two sexes differently.

All the tissues of the body respond in a remarkable manner to the activity at the reproductive centres. Thus, at reproductive maturity, the female, yielding as it were, to the influence of the developing egg-cell, has the characteristics of femininity stamped upon every tissue. In her whole physical organization, and, as a consequence, in her mental and emotional nature, she becomes distinctly feminine. 


\section{Skin Changes.}

The character of the quiescent, well-nourished, large egg-cell in some way becomes impressed upon the whole structure, and there arises the large, comparatively quiescent, well-nourished female.

The reproductive activity of the male, on the other hand, being primarily that of the intensely active, less well-nourished, small sperm-cell, the tissues are harmoniously affected by this all-pervading activity, and the result is a distinctly masculine individual, small, variable, and active.

In the lower life, where there is in every direction less complexity, less variability, these characteristics of male and female are marked.

The female is large, quiescent, stable, and wellnourished; the male small, active, variable, and illnourished.

In the higher life these fundamental sex distinctions also exist, though often more or less modified and obscured.

The whole body of the creature, as we have seen, is profoundly modified by the fundamental, compelling force of reproduction.

Deep and significant changes occur at the time of reproductive maturity. The male becomes stamped ineffaceably by the subtle, concealed forces of sex working within him. The female, too, yields to a mysterious power, acting deep within the cells, and claiming her in the name of her sex. 
In the fishes we usually find the adult female larger and fuller than the male; this is also the case with insects and with many birds, as well as with other forms of life. Among mammals the adult male is generally the larger, this probably being due to secondary causes, which have operated to produce a more powerful male, that being the form best suited to the circumstances in which the animal jived.

Everywhere in life, from lowest to highest, the male tends to vary more than the female.

And as a rule the male is everywhere more active than the female.

Of course there are individuals which afford apparent exceptions to any rule, and there are individual females more active than individual males; but, taken as a class, the propositions laid down are true, and though one female may be more active than a certain male, she probably is not as active as the most active male of her species.

It is never safe to draw illustrations from the comparison of individuals, as life is so complex and so varied that truth apparently exists in all degrees of completeness, and can only be arrived at by much careful examination.

As maturity approaches, the most obvious changes are often those that take place in the skin and its appendages; and although the skin shows great power of variation in both sexes, it usually varies most markedly in the male. The powerful 


\section{Skin Changes.}

and often destructive activity of the reproductive centres finds sympathetic expression in the cells of the skin, and there, too, is a powerful, and sometimes destructive, activity observable.

Scales, feathers, hair, nails, claws, teeth, horns, hoofs, and nearly if not all excretory glands, such as the perspiratory and sebaceous, are outgrowths of the skin. Hence, in them we find marked changes, often riotous growths expressing their superabundant vitality.

Bearing in mind the tendency of the skin to change, it is not difficult to understand the increased brilliancy of color which is a general characteristic of the breeding season.

In certain species of fish the skin undergoes changes which cause it to glow with quite remarkable splendor, some acquiring a livery vying in brilliancy with that worn by the butterflies and beetles.

The bare places or callosities on the baboon glow with brilliant colors during reproductive activity.

The feathers of birds, being direct outgrowths of the skin, at the breeding season, grow more alive-looking, glossier and brighter. The male bird, his cells being perhaps always more active than those of the female, assumes a brighter garb than she wears, unless some special cause steps in to render it otherwise.

In many forms of life, color changes herald the advent of the reproductive period. 
Skin growths of an abnormal nature are frequent in some animals. In certain crustaceans, as we have seen, the skin is modified to such an extent that the female uses it as a nursery for her young.

In the Surinam toad, the eggs having been placed by the male upon the back of the female, the skin grows up about them, entirely covering them and so affording safe asylum for their development. Certain animals possess pouches which are a result of this excessive skin growth, and which they use to rear their young.

Although the skin of the female is often greatly modified at the reproductive season, and these modifications have been taken advantage of and developed by use to serve as aids in the rearing of offspring, the male is on the whole most markedly affected by skin outgrowths.

Nearly all male birds have excessive feather developments; long tail-feathers, crests, plumes, long wing-feathers are common, and sometimes the bird is so cumbered with finery as to be a burden to himself. Japan, for instance, rejoices in a cock whose tail-feathers are many times longer than his body.

These feather growths and the bright colors, originating doubtless in the extra male activity, and then developed, it may be, through inheritance by the discerning love of beauty shown by the female in her choice of a mate, have given to the world the varied beauty of the birds. 


\section{Skin Changes.}

Not only in feathers, however, does the bird express his masculine activity. He sometimes wears a stately comb and gorgeous wattles, and his legs are armed with martial spurs, which he has no doubt encouraged to their formidable proportions by the exercise of another masculine characteristic, the desire to kick out of the way his rivals.

In some species the bird wears his livery all the time; in others, however, the finest plumes appear as a special ornament at the season of love, and the discreet female is said to select the knight of the gayest attire as the father of future generations, thus developing and preserving beauty on the earth.

Dewlaps in cattle, skin folds and excrescences in other mammals, illustrate abnormal skin-growths in the higher animals.

Among insects, the ovipositor, with its formidable armory of saw, file, auger, sting, the complicated intromittent organ, are skin outgrowths, and are generally the product of the imago or sexually mature condition.

Even the wings of insects are a result of the power to vary displayed by the skin, for from skin folds come forth these brilliant gossamers.

Feathers, scales, spines, hair, are closely related outgrowths of the skin, and many males express their masculine vitality in unusual growths of hair at the time of reproductive maturity. The male 
buffalo is buried in a mass of hair about the shoulders and face; the lion develops his royal mane; beards and other growths about the face and head are a common expression of the skin activity in the mature mal:

Horns too, being a skin development, are subject to great variations. Certain deer develop large horns with astonishing rapidity at the reproductive season, these horns being apparently but an expression of the intense vitality seeking mcans of escape, for, the love-season over, these great antlers drop off!

In other creatures the horns are permanent, but do not develop until the period of reproductive maturity approaches, when the horns of the male show yreater power of growth than do those of the femalc; in some species, as in certain sheep and deer, the female is devoid of horns, only the male indulging in this distinctly masculine outburst of skin tissue.

The teeth being devclopments of the skin, it is not surprising to find cxcessive activity here displayed by some creatures.

The wild boar indulges in one or even two pairs of murderous tusks, which he finds very convenient in disposing of enemies, and which he does not fail to develop by exercise.

The elephant, walrus, and seal express their masculinity in the growth of the beatiful ivories which man covets. 
Male horses often have extra teeth, which so far from being a boon, often afford mucl distress, unless man comes to the rescue and extracts them.

The tusks of the male gorilla, we are told, are in size nearly double those of the female.

The skin glands at the reproductive period partake of the general skin activity, and there are even excreted fluids at that time which occur at no other times. In the lobster, as we remember, a sticky substance exudes from the skin of the under side of the body of the female, which she uses to glue the eggs in place, while other crustaceans exude a fluid which serves as food for the young. In some animals the perspiration undergoes a change, acquiring a peculiar and characteristic odor. In some, special glands secrete a substance possessing a powerful odor, by which one sex can be notified of the presence of the other. The alligator, for instance, has two musk-bags under the lower jaw, which, during the breeding season, give a strong musky odor to the haunts of the creature.

Certain insects at times emit a powerful odor from the skin; while, strangest of all, the best accredited scientists tell us that the milk of mammals is secreted by glands which are skin developments.

There are other than skin changes evident in some creatures at the reproductive period; the stickleback, for instance, secretes a sticky substance from the kidneys, and this it uses in weav- 


\section{Life and Love.}

ing a nest for its eggs; while certain cells in the

- lining membrane of the crop in some birds disintegrate and form with the food a milky substance which is regurgitated and fed to the young.

The emotional power of the creature is also greatly affected by the physical exhilaration of the love season. The bird fairly overflows with joy and life, and this happiness it expresses by bursts of song. It sings from very love of love. The more active male here too shows his excess of vitality, for his song far surpasses that of his partner, though she cannot refrain from also singing her song of jubilee. Perhaps she best shows her appreciation by yielding her heart to that gay little cavalier who renders the finest music, thus insuring to the world sweet sound as well as bright color.

Not only in song and happiness, however, is the supcractivity of the love season expressed. Sometimes the exact opposite is the case, and there arises a vehement desire to fight and quarrel.

Even birds sometimes indulge in very unseemly behavior towards each other at this time.

Among mammals a fierce disposition is not uncommon in the adult male. And among nearly all male animals the cruel and sclfish cmotion of jealousy is easily aroused during the breeding season.

This darker side is only one out of many ways in which the activity of the love season expresses itsclf, and in the history of the race this indiviclual 


\section{Skin Changes.}

selfishness is not only advantageous, but perhaps has been necessary to the continuance of the race.

Creatures capable of feeling at all have a sort of spiritual as well as physical rejuvenescence at this season, for reproduction is a unicresal fact. It is an essential part of the activity of every living being, and in all its manifestations claims the supremacy of universality. It is not a local expression, cven in the individual. It reaches to the centre of existence, and affects every part of the being, mental, moral, and physical.

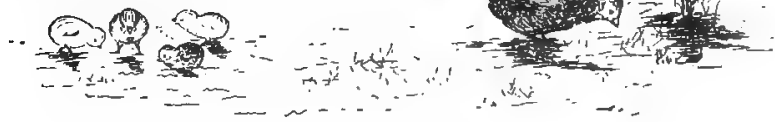




\section{XIII.}

PERIODIC ACTIVITY.

$\triangle$ CTIVITY in reproductive life is, like most A other, possibly all other, activity, periodic.

Periodicity seems to be a universal law of nature, operating in every direction where motion exists; and vital motion is no exception to the general rule; life, too, ebbs and flows in what may be a universal rhythm.

Physical life seems to be but a mode of motion. When motion ceases life ccases, - from the chemical activity by which cells convert crude material into their own living substance, to the more cxternal and visible motions of the body as a whole, this essential fact of motion is evident. And more obscurely, the periodic habit of motion is also evident.

Unseen and for the most part unsuspected, the cell performs its chemical motions of combination 


\section{Pcriodic Activity.}

and disintegration, - grows and dies; the body as a whole wakes and sleeps, grows weary through exercise and rests through repose. Waste and repair follow each other from egg to adult; from birth to death building up and tearing down continually succeed each other.

Nowhere is this periodic activity and repose more marked than in the reproductive life.

A period of fertility and of great activity of the whole organism is followed by a time of sterility and rest.

In all the higher life the reproductive activity has its periods of quiescence when the phenomena of sex attraction, of exg and sperm maturing, are for a time non-existent. During this period of natural rest the organism has opportunity to make good the waste of the preceding generative activity and to prepare for similar future devclopments. For after this scason of rest there follows the season of reproductive activity, when again the eggcells mature in the female, the sperm-cells in the male. As the wave of life rises to its crest in the reproductive system, it produces a corresponding exhilaration in other of the body tissues. As the activity of the reproductive centres increases, the whole being breaks into a spontaneous and sympathetic anthem of quickening life.

The living creature glows from excess of generative vitality, it bursts out in gay colors, in new growths; all the differences between the two sexes 
become exaggerated. And as the difference between them increases, the attraction they feel for each other also increases.

Why they expericnce this powerful attraction for each other they do not know, they only know that in the society of each other alone is contentment, is peace and joy, - in short, is life.

What life is, we do not know. What this power is that attracts one sex to the other, we do not know.

What it is that mutually attracts iron and magnet, or planets and sun, or bodies and earth, we do not know. We only know that everywhere is manifest this strange power which in some way is associated with all matter and all life. We may call it love, or magnetism, or gravitation, but that does not explain it.

We know that in some primal way sex attraction is a part of the general law of attraction everywhere manifest in the universe, and that like all other activities it waxes and wanes, rises to culmination, subsides to rest.

The season of love over, the high office of love discharged, the phenomena of the reproductive period disappear. Colors fade, horns are shed, plumes fall. Life passes from crest to hollow. Sometimes the creature passes on to extinction; where this is not the case, a longer or shorter period of quiescence intervenes between the reproductive renewals. The length of time of this 


\section{Periodic Activity.}

period of quicscence usually depends upon the species of the creature, it being as a rule very definitely marked. It continues for a time, then appear again the signs of the coming season of disquiet, and that strange drama of life is played over again, - the drama so fraught with meaning for the future; the drama upon the successful playing of which depends the continuance of life on the earth.

As the body of the animal grows more complex, so do the forces that play upon and control it express themselves in a more involved manner.

In the single-celled organisms we find an almost mechanical union of two cells.

The protozoa which unite are drawn together with as little consciousness probably as are the magnet and the iron. This attraction which causes them to seek each other can hardly be dignified by the name of love, though the germ of love is certainly there.

In more complex, but still low, forms of life, we find any male attracted by any female, as any bit of iron is attracted by any magnet; that the hunger of one set of cells for the other be appeased is the only consideration.

This too, if it can be called love at all, is but the dawn of that great passion.

Higher, in certain of the insects for instance, we find involved new forces; sex attraction is no longer the simple attraction of one cell to another, 
or of one body to another; the most delicate psychic problems are involved. It is not enough for one creature to be male and another female; there must be other sympathy between them to draw them irresistibly together. There is now choice exercised, principally on the part of the female. It is no longer he who arrives first who wins, but he who pleases best.

Every structural development is now taken advantage of by the male, whereby he can hope to arouse interest in the heart of his beloved. Finding his wings developed in ridges which can be made to sound by rubbing, he eagerly produces his stridulating sounds, piercing the air with his cager love-crics. Wherever his armor admits of sound vibrations, he unceasingly develops this musical instrument by use. Where color is his form of reproductive activity, he displays his brilliancy in his most cugaging manner. Where his ardor breaks forth in weapons, he assures his beloved of his devotion and fearlessness by engaging in gladiatorial combat for her diversion. And she, most charmed by the most actively dereloped of her adorers, selects the handsomest, the strongest, or the bravest for her mate, thus preserving the highlest standard for her race.

In this way is the race modified, sexual selection, as Darwin calls it, playing its part in conjunction with natural selection.

Although courtship among the insects is both 


\section{Periodic Activity.}

varied and entertaining, it is among the birds that one discovers the most pleasing expressions of love.

Love of beauty is a dominant characteristic of the bird, and in its love life its exquisite and fine naturc reveals itself to the full.

Beautiful color, graceful motion, engaging sounds, unite to enhance its happiness. How harmonious and delightful is the love-call of the bird! The shrill, intermittent chirp of the insect is replaced by a flood of melodious and varied song; instead of rasping or beating upon a rude shield, it breathes forth sweet sounds from a delicate throat perfected by love for the purpose.

The love that animates the bird seems to us finer, more subtle, more spiritual than any other love in the lower life. It is not a passion of a moment; the concentrated vitality of its bricf life is not exhausted in one final expression. Its love mounts to culmination, and then instead of being extinguished passes on to yet higher and finer regions, - into the marvellous and powerful attraction known as parental love.

Gleams of this love appear in creatures below the bird in the scale of life; some fishes, for instance, know it.

When the breeding season approaches, certain of them, as the bass and stickleback, make for themselves nests and perform the office of householders and of careful parents, rearing their progeny, 
nourishing and protecting them with the solicitude usually attributed only to higher forms of life.

Why does the parent bass linger about his nest, protecting and succoring the young fishes when they hatch? Why is he not away in the free waters, sporting with the waves, supplying himself with abundant food? Why docs he stay thus in one spot, denying himself the joys of fish life?

Love has conquered selfishness. He cannot leave his tender progeny to an uncertain fate. They will soon grow large enough to swim away and care for themselves, and they will leave him alone, probably he not even knowing them later from the numberless other fishes in those waters.

Those insensate eggs lying in the water, what pleasure can they afford him? They have not the magnetism of his mate which caused every cell in his being to glow with aroused vitality at her approach. What is their society to him? They cannot move in delightful curves with him through the water, they are not bright and beautiful; then why should he sacrifice himself to their uncertain welfare?

Verily, some attraction they have for him, some subtle, magnetic power which links him to the future. In them lies the future, and he, moved by the strange power that causes him to desire the continuance of his race, gives himself to the securing of future life.

Below the bird, except among certain insects, 


\section{Piriodic Activity.}

the care of the young is rare; in the bird it is almost universal, and what is unusual in all but the highest form of earth life, the male too is imbued with a strong parental instinct.

Parental love is one of the blossoms of the plant of which sex-love is the root; less selfish, more altruistic, it is, like the flower, a finer development of the parent stem. 


\section{XIV.}

\section{THE MAMMAL.}

IN passing from the lower to the higher forms of 1 life we come finally to the great division of the

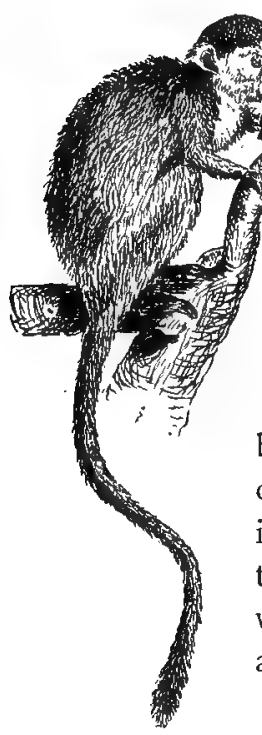
mammals. The mammalian division is an extensive one, and its chief, man, marks it as the one most familiar as well as all-important to us. In it is most fully illustrated, so far as our limited powers of observation now take us, that great faculty we call the mind. This division is made illustrious by that in man which has been called "the mind of the mind," "the inner mind," the psyche, the soul, that by which we aspirc, by which we understand the meanings of life and of the universe.

In this division are to be found man's most familiar friends and allies, as well as some of his more dreaded enemies, - the horse, the cow, the pig (though he does not seem to know whether to class him as friend 
or foe), the dog, the cat, the elephant, the wolf, the bear, the lion, the tiger, and lower down in the scale, the rabbit, the squirrel, the mouse with his big brother the rat, and all the furry denizens of fields and woods. The whales, too, belong to this class, and the porcupine, although so disguised by its forbidding spines, and the bat, in spite of its wings, and the armadillo, in spite of its turtle-like covering, with many others.

The mammal is warm-blooded, like the bird, but unlike the bird it brings forth its young alive and nourishes them with milk secreted by the mammary glands. It is from these glands, or manmæ, as their external forms are called, that this division of the animal world gets the name of mammal.

The higher and more complex the life, the greater the effort to reproduce it, and the more elaborate the devices for conserving the reproductive material.

The lavish waste secn in the fish and other forms is discreetly avoided by the bird; the loss which the insect sustains because of its exposed and orphaned eggs, the bird also avoids by the exercise of intense parental solicitude.

In the mammalian life the conservation of the reproductive material is, as would be expected, carried to a yet higher degree.

Although apparently so different from other forms of life, the mammal too issues from an egg. 
The egg cradles all life. In the lower life it is frankly exposed to view, but in the mammal, and in a few inferior forms, as among certain fishes, this is not the case. The existence of the egg-cell of the mammal is discovered only upon the closest search and observation.

Like the bird's ovaries, the ovaries of the mammal lie deep within the body-cavity, one on either side, but foreseeing the excessive caution to be exercised in producing this most complex of all life, the oviducts do not enter the intestine as in the lower forms of life, but isolate themselves entirely from surrounding parts, having a separate exit of their own.

The size of the egg is not in proportion to the size of the animal, but quite the contrary. The eggs of some of the lower forms of life, as the starfish, are enormous comparcd with those of the largest mammal. The egg-cell of a deer or of a cow is hardly as large as the smallest sweet-pea seed.

In short, the cgg-cell of the elephant would hardly turn the balance against that of a moth. Yet the moth will produce a few score of these large eggs, which hasten to mature in a few months, while the elephant will live sixteen or twenty years before producing any offspring, and will have but a few descendants in the course of a long life.

The development of mammalian life is slow and elaborate. As a rulc, the larger the animal, the slower the development and the fewer the off- 
spring, - though there are many apparent exceptions to this rule, complexity being more important than actual size.

If it is true that all mammals develop from the egg, what then becomes of this mammalian eggcell?

Is it deposited in a cleft in the bark of a tree, or consigned to the cold guardianship of river or sea? By no means. It is not even deposited with parental care in a nest, and there guarded during its slow change.

Or rather it is deposited in a nest, but the nest is not made of twigs, as is the nest of the bird, or of silk, as is the egg-nest of the spider; this nest is an adaptation of the reproductive tissue itself, and lies securely cherished within the parental form.

The mammalian egg, like all others, ripens and leaves the ovary periodically, the frequency with which this occurs depending, as a rule, upon the size of the animal, - it happening oftener in the smaller ones.

At this time, the activity of the ripe egg-cell and of the reproductive centres is communicated to the whole structure; there is a corresponding exhilaration and awakening throughout, and there goes forth that desire of the cells for added life which characterized the fish at the reproductive season, and which characterizes all life. The whole being is charged with a new and powerful vitality; it becomes like a magnet in its attractive power to the 
complement of its own life. For, like other eggs belonging to the higher forms of life, the complex mammalian egg-cell is not alone, in itself, capable of reproducing. It is a feminine cell, it contains only part of the power to develop; the full power must come from union with its opposite; the male element is needed to insure its development.

The sperm-cells, it is scarcely necessary to add, are found in sperm-sacs corresponding to the ovaries, in similar positions in the body-cavity of the male.

Ducts connect the sperm-sacs with the outer world, and the structure at the terminus of these ducts recalls a corresponding structure in the insects, though all is far simpler here. Still, there is external modification sufficiently developed to effect the conveyance of the active sperm-cells to a position sufficiently remote from the outer world and sufficiently within the influence of the egg-cell to result in its attaining its desircd destination.

The sperm-cell, transferred to this strange country by the union of the two sexes, cognizant in some mysterious way of the existence of the yet distant egg-cell, begins its journey towards it, until finally it meets the object of its search, unites with it, and the two, having thus become one, enter upon that wonderful growth which shall result in reproducing the parent form.

If for any reason the creature is isolated and the egg-cell not fertilized, the egg continues its solitary 
course, and is finally launched into the outer world quite dead. If, on the contrary, it has been fertilized, its fate is very different.

Its assured vitality transforms not only itself but its surroundings. It takes a permanent station in a specially prepared stopping-place, instead of passing on and out to extinction.

In the smaller mammals several egg-cells develop at the same time, the young lying side by side in a portion of the oviducts that specially enlarge to accommodate them; but in the larger and higher mammals this is not so. As a rule, only one egg-cell develops at a time, though sometimes two develop. As the egg-cell of the higher mammal ripens, it leaves the ovary and passes through the oviduct to where the oviducts of both sides come together and enlarge, forming a hollow chamber, or womb.

In the diagram is represented the womb, with the duct and ovary of one side only, there not being room to show both ovaries and

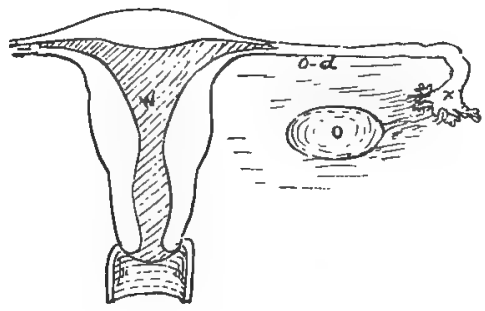
ducts. In this specially prepared womb the egg may meet the sperm-cell and unite with it, if the sperm-cell has been previously introduced there, or it may be that the union between egg and sperm-cell takes place in the oviduct, the sperm- 
cell having hastened along the oviduct to meet it.

Having been fertilized, the egg-cell is not sent into the outer world, but remains to grow and develop in its living nest, in this womb, that, like a loving mother, nourishes and protects it.

This home of the egg, lined with soft, silken walls all embroidered with veins of crimson, and softer than any bird's nest, warmer than any summer ground, is the consummate device of the world's upper forms of life.

In this temple of the feminine world the higher life is perfected. Here it finds a place of peace and growth, leisure and safety to construct those marvellous tissues which make its body. Thus is the womb defined by one of nature's lovers: -

"Looking abroad at the opcrations of Nature, we see an immense variety of devices. Nature works with such skill that man consumes a lifetime in finding out her riddles. The gem is concealed in an almost indestructible shell of rock, the gold in a cleft of granite, the coal and the oil at great depths in the earth, water comes from subterranean courses, the sap rises in the tree in a way yet unexplained, and paints gorgcous colors, gases necessary to life are hidden in an invisible medium we call the air. Life, traits, character, are folded in the egg; and the cogg itself is folded in the water, in the earth, in the nest, and lastly in the womb. The womb itself is the most mysterious 
hiding-place of all, because it is itself alive, is hidden deep within the body-cavity, protected by the bony framework of the body, cushioned with soft muscle, and bound by ligatures of strong material. In this deft house of life it is lapped in crimson robes, kept warm as no other of Nature's designs are warmed. It has poured upon it the best heart's-blood, strong white nerves signal its every want and convey to it the great floods of life out of the reservoir of universal being. As the egg cradles life, so the womb cradles the egg, which here receives that spark without which the earth would soon be lifeless; and here it grows to that day of complete and wondrous joy, its birth.

"So vital to nature's existence is the womb that she has caused her orators to celebrate it and say that out of the Womb of Time has come Liberty, and her poets to sing of what shall come out of the Womb of the Futurc. Out of this sheltered valley spring the flowers of genius and of goodness, asphodels never dying, the life of races. So lovely are the ideas which naturally cluster about this inner temple of the world that the heart itself seems to be but a mechanical, beating instrument, while this one cherishes, clasps, warms, and nourishes."

Thus nourished and safe, the egg grows until it is no longer in the egg form.

If we could look through the shell of a bird's egg there would appear the young bird emerging 
from the chaos of food material in which it is immersed.

Could we look as through a window into the womb of the mammal with its burden of forming life, we should see the young creature enveloped in numerous protecting and nourishing blankets of tissue, slowly taking form. We should see the great blood-vessels bringing to it nutriment so that it need neither eat nor breathe, but may merely lie, absorb the life-giving material from its mother, and grow.

In course of time it is ready to enter the world.

The bird's egg hatches beneath the mother's breast, this also has done that; beneath the mother's heart the young life has formed, not out in the cold world, but safe in the tissues of her body, absorbing her nutriment, drawing her life into its throbbing veins.

The young bird is born; the shell breaks and it looks upon the earth.

The mammal too is born, its time has come, and forth it issues, perfect, - its advent entailing upon its mother the greatest trial she has yet endured for its sake, the terrible birth-pains. But these too she gladly suffers, that she may solace her maternal heart with this new and precious being born to her, and to be yet more fully loved and cherished.

With its advent comes a new emotion into her life. There is born to her, not only her child, but 
a new interest in life, a sweeter and higher conception of life. She too is born with it into a new world.

Profound changes take place in her body during the development of the young.

Reproductive vitality continues at its height, but now taking a very different direction from what it did at first. There is no longer the magnetism that attracted the other sex; the whole vitality is turned towards the completion of the forming life.

The blood flows in a fuller current, and this flow of rich blood spends much of its power in building up the little one.

The mothe: eats for it, she breathes for it; not only this, she prepares for its nourishment after it enters the world, for there now takes place a wonderful transformation in certain of her tissues. The mammary glands develop, those strange inversions of the skin which pick out from the blood a little of every material used in the structure of the body.

When the young come forth this glandular development is complete; not only has the mother's blood been taxed to supply the forming life, it continues to be taxed to supply nourishment to the still feeble offspring.

The young of the mammal enter the world helpless, but the mother does not fail them; again from her they draw their nourishment in the lifegiving milk which she supplies. 
Even the power of the bird's maternity pales before this stupendous accomplishment.

In the mammal, sex activity hastens on to a higher plane of love, a long-continued love of offspring.

During the time the unborn young are developing, and as long as they are dependent upon her care, the mother turns no sex thought to her mate. Only after the beloved offspring have passed beyond the need of her care, and the reproductive activity again expresses itself through the maturing of the egg ccll, does she think again of that other love. During the time that she is nourishing the young, both beforc and often long after their birth, all other reproductive activity is in abeyance; the egg-cells do not ripen; all the vitality is expended in perfecting the life already started upon its career.

Sometimes the mammalian male takes an interest in the support and care of his offspring, but generally not.

True to his primal masculine nature he is more active, more variable, and more egoistic, - in other words, more selfish.

Maternity is necessarily unselfish; the long association with the young, the long sharing with it and caring for it, causes the mother to think first of another instead of herself. This end has been forwarded too, no doubt, by her more quiescent, less changeable nature. Thus has maternity been 
one of the prime sources whence have arisen the altruistic tendencies of the higher life.

Often the effort of the mother to produce milk for her young causes a sad depletion of her own tissues, and it is not uncommon for her to yield her life in giving birth to her offspring.

The reproductive organs are extremely sensitive, and while suffering the changes incident to maternity are peculiarly liable to disease, so that among the higher animals the great balance of compensation swings, and there too death stands as a menace to love. 


\section{XV.}

\section{VARIABILITY AND INHERITANCE.}

$\mathrm{N}$ all life, both low and high, the power to re-

1 produce depends upon a certain resemblance

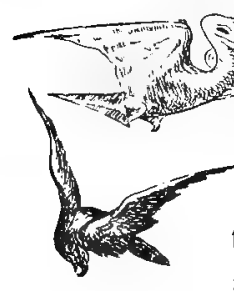
between the two parents. Sex attraction is operative only within narrow limits.

Long ago, we are told, there existed strange creatures on the earth. There were then no birds such as now live, and no mammals.

Reptiles and birds were not yet
separated from each other, but there
existed creatures which were a sort of
mixture of both. In course of time
the descendants of these more decidedly ruptile-like on the one hand, and bird-like on the other.

In early ages all life seems to have found it easier to take new forms than it does now, and so there arose the race of reptiles as a result of cherishing the most reptilian characteristics of the reptile-bird form, and developing these characteristics to the exclusion of others. 


\section{Variability and Inheritance.}

On the other hand certain descendants of the reptile-bird emphasized the bird characteristics and progressed away from the reptilian, until there was developed the race of true birds.

As birds and reptiles receded in structure from each other they became strangers in more senses than one, and lost all power of sexually attracting each other. The reptile was aroused to expressions of love by a reptile like itself, the bird by a bird like itself, and it is owing to this loyalty of the reproductive passion that species remain distinct.

A robin loves only a robin, consequently the robin race is steadfast.

From the lowest to the highest life, is everywhere seen this loyalty to kind.

Reproduction is possible within but very narrow limits; each form of life is isolated from every other form, and even within the physical limits there has arisen the limit of individual choice, so that the robin will not accept any other robin as a mate, but only such a one as it finds personally agreeable.

On the borderland of this physical reproductive limitation creatures can be induced to accept each other, but the result is contrary to nature, as is shown in the sterility of the offspring. The mule, for instance, is the descendant of a horse and an ass, and often possesses no reproductive power, as a penalty for coming from parents too far removed from the bonds of perfect race sympathy. 
On the other hand, the too close blood-relationship of parents is not conducive to robust posterity, and if continued may in time cause the extermination of the race. Horses, for instance, bred from near relatives, are exceedingly delicate, and require more care than those which are of mixed blood.

In some animals near relationship produces offspring defective in some way. It would seem that within prescribed limits, the vitality of an unrelated life were necessary to the highest good of the creature, just as in flowers the best results often come from fertilization from a stranger plant. Nature resents any attempt to curtail that marvellous possibility of variation which comes from the union of two who are not directly connected with each other.

Because of this necessity of the species to reproduce within its own limits, there exists stability of form; because of the tendency of the individual to choose a mate not of its inmediate family, there exists strength and individual varicty.

Mammals, like birds, express choice in mating, and some are said to take their partners for life, the selection being as a rule made, not from the immediate family, but from among strangers.

As a result of this tendency to choose a mate from an unrelated family, the new life through inheritance has a boundless reservoir from which to draw variability and strength, and so may find a permanent place in the crowded ranks of life. 


\section{Variability and Inhoritance.}

Whatcver increases the creature's power of varying increases its possibility of progressing. For it is through the mysterious power of inheritance combined with the power to vary, shown most actively by the male, and transmitted by him to his posterity, both male and female, that animals finally reach that form which is best adapted to their particular surroundings, and which, as life evolves, is expressed in ever higher forms.

In time of peace and plenty and freedom from all hardship, most of the creatures that are born will live, no matter in what way they may have shown variation; but let there come a time of hardship, and those which have the best endowment of strength, or other quality for resisting or overcoming the adverse conditions, will live, and the less fortunate perish. The descendants of those that survive, inheriting their characteristics, will the better survive, and in course of time, after many weedings-out of those less capable of enduring the conditions, there may be formed some particular variety of creature of a distinct and definite form.

This power of the creature to come into harmony with its surroundings depends upon two things, - its ability to vary, and its ability to transmit its new powers through inheritance.

Variability and inheritance are the most important factors of reproduction, and to these powers is owing the multiform variety and beauty of life on the earth. 
Natural selection and sexual selection doubtless help to determine which of the numerous forms constantly arising shall continue. Among the plants, as we have seen, the insect makes itself a Providence, determining form, color, odor. And among certain animals man performs a similar office, taking the place of Nature in creating circumstances for his own purposes or fancy, and by knowledge of the laws of inheritance and reproduction causing the animal type to vary at his will.

Desiring to develop certain characteristics, he removes the animal from surroundings unfavorable to such development. Plump cattle being advantageous to him, he feeds and shelters his flock so that the more tender may survive as readily as any; then by selecting those males and females most prone to accumulate fat, he obtains in time a breed of animals easily fattened and of tender flesh. If milk is his object, he proceeds in the same way, feeding abundantly, and sheltering, knowing that nutriment and warmth are conducive to reproductive activity; and selects for breeding purposes the best milk-givers and their male offspring.

Thus has man made himself a Providence in the case of many of the lower animals, modifying them in almost any way he pleases by continual selection. He has developed long-horned, and short-horned cattle, short-legged sheep and almost no-legged pigs; has modified the coats of sheep 


\section{Variability and Inheritance.}

and goats, the feathers of birds, the forms of horses, the forms and instincts of dogs; there is no change which he has not at some time or other produced in some of the lower animals.

Man has no power to create $a^{\bullet}$ form, he has wisdom to take advantage of the great power to vary which characterizes the higher life; and when for some obscure reason there arises a form useful to him, he sets it apart, protects it, nourishes it, and makes it the progenitor of many descendants.

If the short-legged sheep born one day in New England had belonged to a herd roaming over difficult places it would not have survived. The fact that it could not jump was no disadvantage to it in its master's fields, and to him the fact that it could not jump being a distinct advantage in fence-making, he carefully preserved the shortlegged lamb, and its short-legged descendants until he had a flock of short-legged sheep, much easier to control than the ordinary long-legged variety that delighted in jumping over walls and fences.

Man has discovered that by the application of intelligence to the laws of nature, any animal life may be changed.

Fine qualities and great beatuty may be developed, gross qualities and ugliness eliminated.

Nor is this power limited to the physical growth. Intelligence, gentleness, and affection may likewise be evolved by the same methods. 
Impressed upon egg and sperm-cell are not only the physical characteristics of the ancestors, but also their mental and emotional characteristics.

A fine mind and a good heart leave an immutable impress upon the reproductive cells, so sensitive to whatever affects the life to which they are united, and which it is their office to pass on.

Although they appear so small to us, they are boundless in capacity to receive and retain impressions from their universe, the living body.

They are like the human mind in this limitless power of receptivity.

Strange, vital cclls, apparently but tiny drops of protoplasm, apparcntly as simple in structure as the amoba, they force us to bow before a mystery as limitless as it is sublime.

No wonder that the ancients avowedly worshipped the mighty force of regeneration. Strange that any should stand insensible to its beauty and its holiness. 


\section{XVI.}

NUTRITION AND REPRODUCTION.

W

THA is the immediate cause of reproduction? What informs the creature that the time for providing for future generations has arrived?

To answer this question let us return to the amoba.

We are told that a division into two is necessary in order that the creature by diminishing its size may obtain an adequate food supply. Of course the bulk of protoplasm which composed the body would in. crease much more rapidly than the surface; and as food is received from the surface only, there could not be sufficient to nourish the creature beyond a certain size. So the first cause

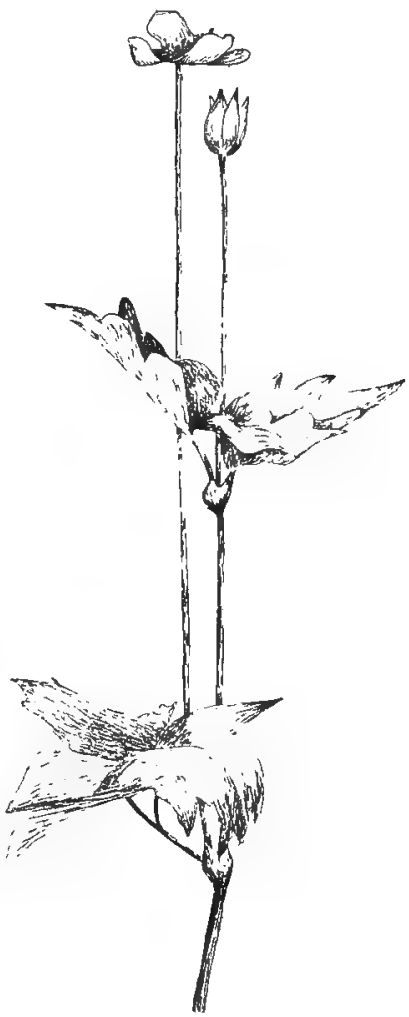


of reproduction, if this be true, is hunger. The desire for nutrition, that is to say starvation, causes the creature to resolve into small portions which can be more easily nourished than the larger lump.

Likewise, the attraction of one single-celled creature to another is explained as a desire for added nutrition; two starved individuals coming in contact absorb each other, in other words, unite their waning vitalities, and thereby gain new vigor.

One thing in favor of this theory is the fact that reproduction takes place in the low forms of life, as a rule, when the parent nears the end of its vitality. It springs into existence, waxes, wanes, reproduces, dies, - reproduction being in this case, perhaps, a memory of those past ages when all life was that of the single cell, and when it preserved its existence by division, or by union and division. So now it preserves its race by this resolving again into single cells, - though these cells themselves are all that continue.

"My vitality is decreasing," it seems to say, "my life is going out; I will produce again my primal form of a tiny protoplasmic cell, and thus save myself."

But it is no longer able to divide its whole substance into these cells; only one tissue in its body responds; and foreseeing the lessening vitality, it buds off portions able to live and develop once more into the complex adult form. The form itself, all but these fortunate cells, perishes. 
What is true of the lower forms of life in this respect is essentially true of the higher; reproduction does not normally take place during the period of most active growth.

The higher animal, starting as an egg, makes marvellous gain as it develops from the simple egg-cell to the complex animal built of countless cells; it absorbs nutriment and builds up its body, the gain far exceeding the loss. So active is its life, so full, that it increases in size and complexity at a rate which must appear marvellous when one stops to consider it. But this gain, this phenomenal growth is not unlimited; there comes a time when the creature grows less rapidly, there is a diminution of the building-up force; this diminution in the creature's power to increase in size hints at coming dissolution. There may be a long period of balanced existence, when loss and gain virtually equal each other, when bodily and mental power are at their best, but there is an inherited memory of death, and there is felt the desire for help, perhaps for nutrition; there seems to be a forecast of inability to continue growing, and the old remedy, the remedy descended from the age of single-celldom, is resorted to. "I must diminish this vast mass of cells which packed so closely together will not always be able to find renewal; I must resolve again into primal simplicity; I must break up into simple units," it seems to say, and forthwith finds the body too complex to resolve 
again into single units, - only one primal tissue remembering the old, saving method, and budding off single cells to live and grow.

So in all animals when there approaches the time of diminishing growth, with the lessening of the surging tide of life there is developed the reproductive activity; like the amoba, which, finding its life waning, gathered its forces together and separated into two parts, does the higher life, perhaps as an inheritance from its single-celled origin, concentrate its vitality in the production of these life germs.

Having been so abundantly nourished that it not only could sustain life, but could add to its bulk, it reaches a point where this vital power of storing up and growing ceases; and as this grows less, the reproductive activity increases.

We say the animal has its growth; what is that but saying its tide of life no longer is rising?

It pauses at the turn of tide; then follows a period of longer or shorter duration, in which loss and gain balance each other, the impetus of growth sometimes continuing in a lessening degree for a period after reproductive maturity.

Reproductive activity is at its height for a season, the wave of life is at its crest, then the balance is on the side of loss. Vigor gradually departs; we say the animal is growing old, - finally the incvitable cessation of the vital forces ensues, and death results. 


\section{Nutrition and Reproduction.}

Thus is the drama of life played among the highest creatures as it is among the lowest, - with this difference: in the higher life the whole process of decline and decay is retarded, - life does not pass suddenly to the catastrophe, as it does in the case of the butterfly.

But even here Death stands ready to follow Love. The season of love is a sign of coming dissolution. Here too, as in the amœba, an incipient starvation is felt, though not recognized as such.

In the salmon the glow of the skin does not proceed from excessive nutrition; on the contrary, it is the result of increased activity, joined to lessened nutritive material; for during its season of reproductive activity, although such profound changes are affecting its body, it does not eat, and the great changes are effected at the expense of the material already accumulated. The skin changes are in truth a form of disintegration, of breaking down; they speak of death rather than of life. This again recalls the butterfly, with its superactive winged life and its delicate nutriment; and the final death of the salmon, unable to recover from the stupendous reproductive loss, again recalls the fate of the butterfly.

Most of the skin changes which occur at the reproductive period are, from a physiological point of view, waste.

The overwhelming and sometimes fierce demand 
for love is the cry of starvation, the fear of death. This condition, the individual supposes, concerns himself, but instead it concerns the race, he being but a means to an end. The race must live; the individual, at any cost, must provide for this; there must be no possibility of failure. So the instinct of race preservation is in some instances greatly overbalanced, and in individual cases may cven operate to the injury of the individual.

Not all creatures encounter death as the immediate successor of love, but be the interval short or long the sequence is the same, and in all creatures reproduction is a sign of coming physical dissolution, and is always more or less exhaustive to the parent.

In the lower forms we see the parent entirely consumed in producing offspring. When the protoplasm of two cells of spirogyra, for instance, has united for purposes of reproduction, the life of that filament of spirogyra is at an end. The beautiful filament with its bands of green is deprived of all life - it falls to pieces - it dies. Only the united cells of protoplasm or "spores" remain to produce new filaments another season.

The parent lives in the offspring, its own individuality ceases, it dies and disintegrates, - continuing its earthly life only through its power of reproduction.

Wherever there is special activity in the reproductive centres, there is a corresponding brief 


\section{Nutrition and Reproduction.}

exhilaration, followed as a rule by exhaustion. During, or immediately after, the breeding season, the animal is unfit for food; every one knows how flabby and tasteless the oyster is during the r-less months; its plumpness and firmness have been sacrificed to the production of life-germs, just as the richness and food value of the salmon, and of all fishes, are sacrificed at that time to the same end.

Abundant nutriment favors reproduction, as is shown in the case of insects, which, finding abundant food, multiply with astonishing rapidity. All other animals are subject to the same law: given abundant food, and the individuals rapidly increase in numbers; diminish the food supply, and there is a corresponding reduction in births, - both within limits. Excessive nutriment, like absolute starvation, may prevent reproduction, - the vitality appearing to expend itself in disposing of the unnecessary material.

While abundant nutriment favors reproduction, lack of nutriment, within limits, hastens the reproductive period; that is, the power to live and grow sooner reaches a climax, and dissolution sooner manifests itself in the effort to reproduce.

Warmth, as favoring nutrition, precipitates the reproductive period; so that the inhabitants of warm climates mature younger than those of cold climates.

If, on the other hand, the climate is very cold, 
so as to retard nutrition below a certain point, the reproductive period is hastened, not as a sign of abundant nutrition, but of the exact opposite. Here, as elscwhere, we find opposite causes producing like results.

It is an intercsting fact that abundant nutriment favors the production of females; thus, certain insects, during the scason of the most abundant food supply, lay eggs from which issue females, while the later, less weil-nourished eggs give birth to males.

During a prosperous season, too, or for several successive prosperous scasons, females may be the only forms produced, the eggs containing vitality enough to develop without fertilization. Now comes a change, food grows scarce, the less welinourished female lays eggs, and from them issue males!

The fertilized, therefore better nourished, eggs of the queen bee develop into quicns or workers, which are imperfect females, while the unfertilized, ill-nourished egss are those from which proceed drones. The young queens, too, are fed upon a specially nourishing food, which enables them to perfect the female type.

Even in the higher forms of life the sex of the offspring is intimatcly associated with nutrition, abundant nutrition resulting in the formation of females; scant nutrition, of nuales.

This does not necessarily mean that the con- 


\section{Nutrition and Reproduction.}

sumption of abundant food on the part of the mother will result in the production of female offspring. This is doubtless true in the simple, lower forms of life. In the higher forms it may not be true. The various tissues appropriating food with unequal readiness, one kind may thrive and the creature present a well-fed appearance from an accumulation of fatty tissue, while the reproductive tissues have more feebly appropriated nutriment, and produced as a result males.

In the higher life the production of male or female seems to depend upon the power of the generative centre to appropriate nourishment.

It is probable that abundant nutriment, warmth, and composure tend to the production of females, even in the higher forms.

Since reproduction and nutrition are so intimately connected, it is not surprising to find that the age at which the reproductive system matures is a gauge of the length of life.

In the higher animals, the length of life seems to be four to five times that of the period of maturity; thus, the dog, which develops at two years of age, has a life lease of about ten years; the cow, which becomes sexually mature at two or three years of age, lives from twelve to fifteen, and the elephant, which is not sexually mature until about twenty, lives a corresponding length of time.

It is also worthy of note that in early youth the weaker, less well-nourished male succumbs sooner 
to privation than the stronger, better nourished female; so that where there is an excessive number of males produced, particularly in the higher life, a correspondingly greater number die during the period of infancy.

Thus is reproduction, in all its manifestations, in some deep way, closely related to nutrition; the frst great need of the individual is in some obscure manner also the first great need of the race. 


\section{XVII.}

VALUE OF SEXUAL REPRODUCTION.

TNTERESTING and eventful as is the fact of 1 reproduction from the union of two, there no doubt has arisen in the minds of many the query, What is the necessity for two sexes? Why could not the result be more easily and economically obtained by one.

Why cannot perfect reproductive cells be budded from every creature, perfect cells containing within themselves power to develop into perfect beings?

There are several deep-lying reasons for the dual necessity, some of which must already have suggested themselves to the questioning mind.

Remembering the history of certain of the protozoa, and how the union of one with another was a matter of self-defence against starvation, then recalling the close relation between reproduction and nutrition in all creatures, it may not be unreasonable to suppose that the effort of higher life to produce the complex and vital reproductive elements is so great as to demand a division of labor in the first place, and the union of forces in the second. 


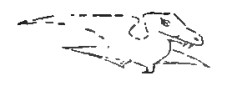

Doubtless there was originally but one sex, - from the simple substance of the F simple creaturc ucre budicd reproductive cells capable of developing with$-\frac{3}{3}$ out union with other culls. Gradually, as the life became more complex, there was a division into two sexes.

Hints of the original one-sex method still linger in curious and instructive abundance, however, - certain creatures still reverting to it upon occasion; some insects, for instance, at certain seasons of abundance laying eggs which develop without fertilization, while at other seasons, of diminished abundance, the eggs are always fertilized.

There are crustaceans which have the habit of laying eggs capable of devcloping without fertilization, and high up in life, even to the mammals, there have been observed the first changes in the unfertilized egg, -- changes

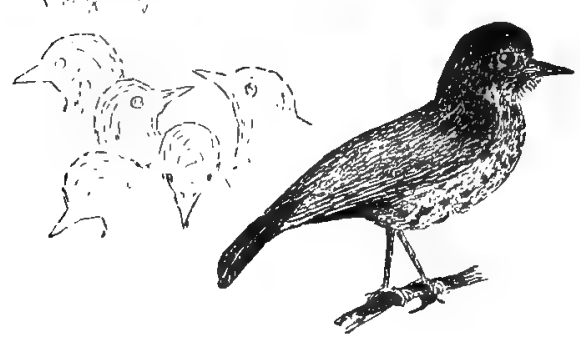
which usually take place only after fertilization. These changes proceeded but a little way, however, never de-

veloping into the later stages. 


\section{Value of Sexual Reproduction.}

Gradually, as the life became more complex, there were evolved creatures that budded off two kinds of reproductive cells, one individual developing both kinds. Traces of this primitive hermaphroditism are found in all the higher life.

Even in the highc:s mammals, including man, the reproductive glands are at an early period neither distinctly male nor female; for a certain length of time it seems to be uncertain whether the developing egg will produce male or female. In the forming life the beginnings of the reproductive organs of both sexes are present. Later, conditions of nutrition seem to have decided in favor of one or the other, and the male organs are gradually developed at the expense of the female, which linger as the faintest traces, or the reverse is the case.

So, as life advanced, the original hermaphrodite developed to perfection but onc set of reproductive cells, and thus there was a division of labor effected.

In the embryo, as the creature developing from the egg is called, there reside the germs of both sexes, but in all the higher life the germs of only one sex finally develop in an individual.

Tremendous vitality is employed in the production of reproductive cells, - so great that, if this reproductive activity in the higher life be prevented the whole organism un lergoes change. Instead of being muscular and active, it becomes obese and sluggish. The nutriment that otherwise would have gone to the production of reproductive ele- 
ments and activity, under these changed conditions, concerning which more will be said later, is used in storing up reserve nutriment in the body.

The higher the life, the more arduous the task of reproduction; for which reason there doubtless has been evolved the division of labor resulting from the employment of the sexes.

The final union of the two cells themselves has not unjustly been attributed to the same reasons which are supposed to draw the two protozoa together. An incipient starvation on the part of both may have led them to unite, attracted by the powerful magnetism which exists between these different atoms. It is the active, ili-nourished male cell that always seeks the passive, well-nourished female-cell and dissolves into its substance.

The particular need of the female cell seems to be stimulus rather than nutrition.

Stored up in the egg of a fish or a bird is power almost sufficient to develop into a new being, but it cannot quite accomplish this stupendous feat. Impressed upon each tiny egg-cell in some mysterious way is a memory of the whole ancestry of its race, - of the individual peculiarities of its parents as well as of countless ancestors.

Is it any wonder one egg cannot complete the whole process by itself?

It desires help, it seeks more powcr, and this it gets from a cell apparently unlike itself and having power by this very unlikeness to impart to it that 


\section{Value of Sexual Reproduction.}

vital impulse which shall cause it to overcome its inertia and take upon itself the prodigious task of producing again that complicated and delicate structure whence it issued.

Such a task might well appall. And well might the single cell hesitate and wait for inspiration and help to fulfil it.

This stimulus and inspiration the male-cell is well adapted to bestow. Its excessive activity, united with the excessive nutriment of the femalecell, produces the conditions necessary to enable the now complete cell, the cell which is now in a high degree both male and female in its power, to achieve a growth which shall result in a new being.

Thus does the separation of the two sexes conserve the power of the creature.

Whatever first caused the separation of the sexes, the result was that re-enforced vitality and power of variation upon which the activity of the higher life seems to depend.

So unless this separation had taken place it is difficult to see by what means the higher life could have arisen.

The higher life then owes its existence to sexual reproduction.

Activity is essential to life, and the higher life seems more dependent upon variety to maintain its complex activity than the lower life; so that where creatures nearly related breed together, the lack of difference between them results, in many instances, 
in enfecbled or defective offspring, and these being unable to perform the arduous necessitics of life, their family may die out.

In animal life, as in other forms of motion, the equilibrium must not become stable, or else motion ceases. Cessation of motion in living matter means death.

So the higher life has pursued its remarkable upward career by virtue of having established methods for securing variation.

The most important and effective cause of variation is the production of offspring from the union of two. For instance, instead of having one grandparent, the creature which is the result of sexual reproduction has four. That is, from four inmediate different sources has come vital power and variability to the individual.

To appreciate the meaning of sexual reproduction, look back along the ancestral line for twenty generations. If there was but one parent, in twenty generations there would be but twenty ancestors - but twenty individuals from whom to inherit possibilities. No, not twenty, only one. For all these twenty ancestors would be but continuing divisions of the same individual, so the same characteristics would be repeated over and over again, the final descendant differing from the first only in so far as the natural tendency to vary, which seems inherent in all life, had triumphed.

Where there are two parents, how great is the difference! 


\section{Value of Sexual Reproduction.}

Two parents means four grandparents; alld as each grandparent had in turn two parents, that implies eight great-grandparents; and, having gone back twenty generations we are confronted by the creditahle number of one million forty-eight thousand five hundred and seventy-six ancestors!

Think of that! In twenty generations each descendant from two parents has had over a million ancestors from whom to inherit power!

Certainly there need be no lack of varjety here.

One ceases to wonder how certain individuals, unlike the rest of the family, have come by their characteristics.

Somewhere among that long line of ancestors a long forgotten one has been revived in this stranger in the family.

Marvellous beyond telling is this power of inheritance. On the tiny egg-cell, and yet more tiny sperm-cell have been ineffaceably stamped the characteristics of countless ancestors, - these characteristics some day to be unexpectedly revived in a remote descendant.

This wonderful power to vary, which in the higher life seems to be intimately connected with the power to live, gets its greatest impetus from sexual reproduction.

Thus is the production of the higher life from the union of two not only necessary, but the greatest of all nature's achievements, insuring boundless vitality and infinite variety. 


\section{XVIII.}

INDIVIDUALITY.

THE power of variation has raised the animal

1 world from the condition of simple protoplasm to one wherein is found the complex intelligent being.

Without power to vary, all life would have lain prostrate in the form of undifferentiated protoplasm.

Whence came this restless, compelling impulse to change?

All we know is that it resided in the protoplasm.

The great Lamarck made intelligence one of the attributes of protoplasm, - not conscious intelligence, but an inherent force inevitably worling towards a definite end.

It was he who said, "Animals vary from low and primitive types chiefly by dint of wishing; " and he was well laughed at by the world in consequence.

Perhaps the world laughed too soon.

"Animals vary upward by wishing." Lamarck spoke as a great poet when he said that; and it is, after all, the poet who illuminates the truth and 


\section{Individuality.}

makes it visible to man. Science struggles with contradictory facts until the whole subject is one day made luminous and consistent by having passed through the revealing light of that higher scientist, the poet.

If Lamarck's divination is true, there must have been impressed upon the primitive protoplasm a clear, far-reaching aspiration, which, all unconscious in the lower life, raised it through form after form, until the conscious life of man was reached. Man, as we know, does vary upward by dint of wishing, or as Emerson so well expresses it, "We do not what we will, but what we wish."

And is it not a stimulating thought that this unity of design has run through the whole plan of life development?

Nor does this conception of the cause of progress interfere with that evident condition and formative power already explained as natural selection. The progress must be within certain physical limits, and within these limits the life is held by the circumstances about it. In other words, all things must be in hamnony with each other. As long as a plant or an animal is in harmony with its surroundings, with the soil, the climate, the neighboring life, all goes well with it, - but if it fall out of harmony, if the universal rhythm that seems existent in all things be broken, then the plant or animal must pay the penalty of discord by ceasing to live. 
"Natural Selection" is but a way of expressing the result of inharmonious relations. A certain harmony between the organism and its surroundings is absolutely essential to its existence. But within these physical limits there is opportunity for great variation and great aspiration, - these oftentimes forming one of the factors in the law of natural selection, the "fittest" sometimes being the most intelligent, the bravest, the most beautiful or the most noble.

It may, then, be true that the divine benediction, the necessity to go upward, placed upon the simple, potent life-basis, way back when earth conditions were such that only it could live, drew it ever upward and upward, until man himself emerged from the apparent chaos to show the meaning of the multitudinous, struggling, half-perfected beings, whose imperfection was the price of his perfection.

Impressed upon the earliest protoplasm was this upward tendency, by which it departed from its condition of simplicity, became complex and individual, sexual reproduction being the method employed by the real agent, love.

In the lowest forms of life there is probably little difference between individuals. One amœba is very much like every other amœba. But impressed upon the early protoplasmic forms was the power to vary, the desire to vary, and so life streamed upward, one species after another emerging, each 


\section{Individuality.}

upward impulse resulting in a creature of greater individuality.

After there was sufficient differentiation in the beginning forms of life to produce two distinct sexes, thus bestowing great power of variation through many ancestors, the gain on the side of individuality cannot be overestimated.

Individuality is the beneficent result of sexual reproduction.

Power to vary, power to be different from others, power to be one's self, distinct from every one else, - this is individuality, and this is the boon sexual reproduction has given to the world.

From sexual reproduction as a starting-point have come too, by slow degrees, the higher faculties.

Through it has come a knowledge of the joy of sharing the strongest and deepest pleasures with another. Sexual reproduction made impossible that frightful selfishness which must have characterized all life, if each individual had lived alone and for self, or even for self and offspring.

Sexual reproduction bestowed at the same time individuality and universality.

It created the individual; it forbade the individual to live for himself alone.

On a low plane at first, it passed upward to illuminated regions.

- Love has given the initial motion to intellectual and spiritual life, and is still the most powerful force of earthly existence. 
Although scx has created the inclividual, sex activity is not the property of the individual. The being who makes the mistake of supposing this, and of subverting the office of sex to purcly personal use, pays the penalty of the breaker of primal laws.

The function of sex is for race purposes, not individual purpose. Nature works ever on a grand scale. She creates individuals, but never an individual.

The individual in the process of evolution is always sacrificed to the race, which, for the time, is nature's unit. Sex, therefore, does not belong to the individual, but reaches out through him, and past him, into that greater, more important fact, the race.

Hence individuals frequently suffer loss and even death, that the greater end may be accomplished.

Yet, contradictory as it may seem, the individual is evidently the final end of nature's aim. The final completion and perfection of the individual is the ultimate end of the race.

As life advances it tends to become more and more individualized. The individual tends to control the race. The man of genius, the most highly individualized of created beings, has the power of generations of ordinary mortals. His influence outweighs that of multitudes of other men, and may ultimatcly affect the thought, and consequently the life, of his whole race. 


\section{Inclividuality.}

The meaning of this apparent contradiction is clear; through countless imperfect individual forms does life pass, ruthlessly crushing the too imperfect, ruthlessly chastening the multitude, to attain finally a more perfect individual life.

Meantime, all through life, from lowest to highest, the struggle of individual against race goes on, always to the defeat of the individual. Half blessed by a partial knowledge of the joy of life, the full knowledge is conccaled in the future, and it is to the final revelation of this that life, aspiring, baffled, still struggles upward.

Nowhere is the struggle between individual and race more severe than in the reproductive life.

To attain race ends the reproductive faculty is, as Emerson expresses it, vastly "overloaded," particularly in the highest of all life, where the accomplishment of race ends is most important.

For this highest life all life has in one sense existed; through the upward struggle of multitudinous lower forms human life has emerged, weighted with many fragments of unsloughed imperfections, blessed with a great cumulative torrent of upwardtending desire.

Partly, perhaps, because man remembered past pleasures and desired a repetition, even when no physiological necessity impelled him, and partly through ignorance of the laws of life and happiness, which cannot be violated without full payment of heavy penalty, he has precipitated upon his race 
and fastened there an inheritance of abnormal generative activity, which it devolves upon the enlightened race of the future to restore to normal condition. Because of these early mistakes the human race has suffered inexpressibly through its generative power. It is at once individual man's highest blessing and his greatest misfortune.

Himself highly individualized, he has sought to put himself before his race. He has not understood the universality of his importance.

He has not fully learned how to use his most important physical function in strict obedience to nature's law of race progress, and at the same time derive from it the highest individual benediction. He has not fully reconciled himself as an individual to himself as a universal force.

As life has moved upward to the present man's creation, so will he by immutable laws be compelled to move upward to the perfection of the man of the future.

Nature is inexorable. As ruthlessly as she has sacrificed individuals to the good of the race in the past, will she continue to sacrifice them to the good of the race in the future.

From the beginning there has been produced an infinitely greater number of living beings than the earth was able to nourish. From the lowest to the highest life this overcrowding has been constant. More offspring have been produced than could by any chance survive. 
At first glance this seems an unnecessary and cruel waste of life, but a moment's reflection shows that nature made no mistake in her cosmic plan when she so decreed, for out of the great struggle for existence which was thus rendered necessary, there came progress. Only the strongest or wisest or best in some direction gained the advantage of their circumstances and lived. And ever

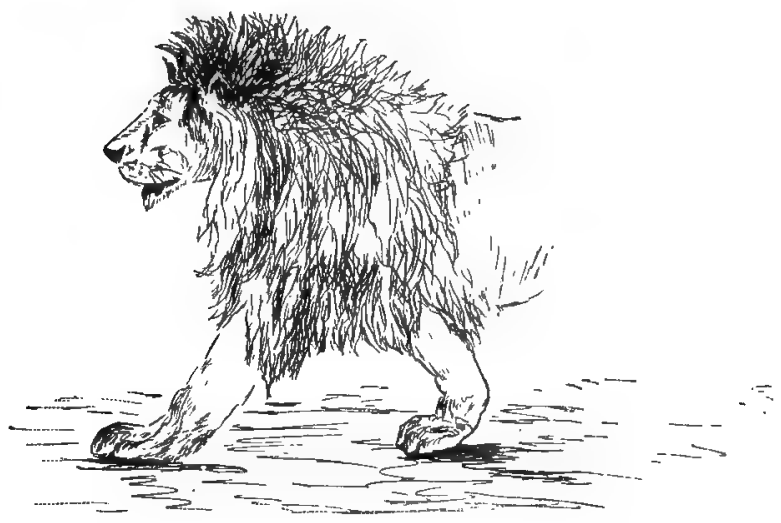

the great struggle went on, generation following generation with here a little gain and there a little gain, until there emerged from the progressive conflict life as it exists on earth to-day, varied, beautiful, still in conflict, still progressing. And on it will go. Whatever is unlawful, inharmonious, unbeautiful in its relations to the universe must die. 
Sex-life too is struggling towards perfection; the problems besetting it are many, and cannot be fully answered to-day, but the future will certainly answer them fully, and to the highest good of the race.

Change of thought and custom are a part of the history of the past, and will be of that of the future; but this contains no menace.

The tendency of life is upward, and upward it will sweep, - perhaps not without faltering and pausing, or even apparent temporary retrogression; yet, nevertheless, inevitably. 


\section{XIX.}

MALE AND FEMALE.

THE beantiful variety which social life displays with its harmonious inter-relations, is the outcome of sexual reproduction, and depends upon the inherent differences betweer. male and female, and their methods of adaptation to each other.

Since sex is so universal, and since the sex characteristics remain the same from highest to lowest, the results of sex life are essentially the same through the whole cycle of living things.

The fomale is the first form of life; primitive, un-

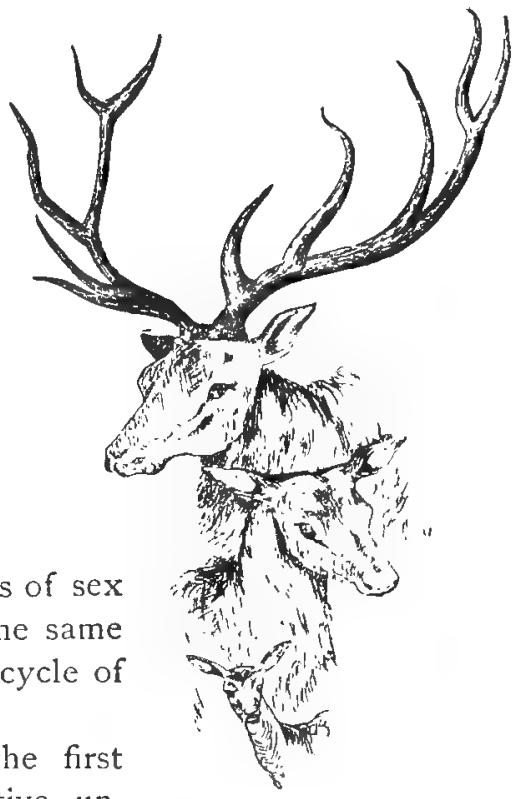
changing, lasting, she represents the conservative element of life. 
The male, born later into a world not wholly reconciled to him, fighting his way to a permanent place, eager, restless, dcsiring change, represents the progressive element of life.

At first small, insignificant, only half necessary to the continuance of the species, in some cases a mere parasite on the female, in other cases doomed to die or to be put to death by his own companions as soon as his race function has been performed, gradualiy he has achieved permanence and importance, exercising his power of variability and activity, until finally he has, in some instances, turned the tables and even essayed to dominate the female life, which, calm, stable, has kept steadily on, retaining its primitive characteristics through the most diverse conditions. Thus it has come to pass that the mammalian male, big of bone, strong of muscle, fierce of temper, has constituted himself, in some cases, the ruler of his species.

Although, in the higher life, the creature is even at birth stamped with many of the characteristics of its sex, these characteristics are not fully developed until the time of reproductive maturity. $U_{p}$ to that time there is comparatively little difference between the members of the two sexes.

They are impersonal, alike. At reproductive maturity they rapidly diverge and become unlike. $\mathrm{Up}$ to this period there is no special attraction on the part of one for the other, but after maturity this is different; as the unlikeness between them increases, the personal attraction also increases, 
They recognize in each other an individuality different and agreeable.

Sex maturity is to the individual what sexual reproduction is to the race.

It bestows strength, variability, individuality.

Although it is so often the harbinger of death, while life does continue it is literally transformed and illuminated by the mighty power of the perfected sex activity.

When the caterpillar, for instance, passes through its pupa form and emerges as a butterfly into its sexually mature state, it is a different being from what it ever had been before.

It seems to have entered upon a finer and higher life; it has cast aside the more earthly for the more spiritual form.

Its pleasures are of a different and higher type. It has become complete. Life in it glows in a warmer and brighter flame.

Love is the cause of this transformation. To the butterfly the condition of love, the power of love is life, this winged, bright life; the cxpression of love is death. Isolate the butterfly so that he lose not the vital reproductive principle and he continues to live. The love flight having once been taken, death is his portion.

This close connection between love and death is everywhere apparent in the lower ranks of life. in many instances the act of reproduction terminates the life of the parent. 
The same mortality is remotely apparent in the higher ranks.

The biologist proves beyond question that reproduction is a process of destruction, that where this power announces itself, it is a sign of coming dissolution. Death is the price the many-celled creature pays for its more complex form, its higher powers.

As the insect lives the higher life for a brief period, and then dies as the result of this beautiful development, so does the higher animal live its life of conscious joy and sorrow, and then die as a a result of this power of consciousness.

Only the single-celled organisms, which have no conscious life, no great ecstasies or aspirations, live on with no necessity for death.

Yet none would choose the immortality of the amœba, with its simple unseeing life, as a condition of this immortality.

"Better fifty years of Europe Than a cycle of Cathay"

is applicable all along the line.

Death would be beautiful and welcome, were it the necessary condition of cven but one moment of conscious life and knowledge.

A single moment of intelligence followed by earthly oblivion, were worth countless ages of unconscious protoplasmic life.

Although beproduction is incipient death, yet does it also express the fullest life. Its advent 
shows life at the crest of the wave, and while in low forms the reproductive period is quickly passed and life ended, in higher forms the life is protracted. Instead of one tremendous effort resulting in many offspring and involving fatal parental sacrifice, there are recurring efforts resulting in but few offspring at a time, and terminating less tragically to the parent.

So complex is the higher life that but a limited number of descendants can be perfected at one effort.

So here we see the flame of love, instead of bursting forth in one great consuming conflagration, glowing in a steady fire that periodically bursts forth into more intense activity, then subsiding, but never dying, warms and vitalizes continually, intensifying and exhilarating splendidly at these recurring intervals of increased power.

The transformation worked by love in the higher life is as great, though not as apparent, as that worked by it in the butterfly.

What might be termed the larval state of the mammal bears no outward resemblance to that of the insect. Yet the young mammal is a very different creature from the adult form. As maturity approaches we know that all the tissues of the body undergo change. The young creature emerges from nonenity to individuality through the acquirement of sex power.

- The young mammals of any given species much 
resemble each other in form, in disposition, in voice ; there is little to distinguish them. As reproductive maturity approaches, a subtle change passes over them; gradually each creature frees itself from the uniformity of childhood, and becomes an individual with distinct personality and marked characteristics.

The whole structure, as we know, responds to the stimulus: the female grows more distinctly feminine in outline, less rugged, more delicate; the male acquires a new robustness, grows large and powerful, with increased strength to match the increased size.

This is life at the crest of the wave. Growth ceases, the creaturc lives on for a certain time, full of vigor and power, perfect in every part. In the higher life the sex development, as a part of the general body development, so powerfully affects the life that one almost loses sight of the primitive meaning of reproduction, - that it is the forerunner of certain dissolution.

The universal baby form is lost, the individual form is found; the larva becomes the imago.

In the lower life, change of form is to human ken the most conspicuous change; in the higher life this is no more marked than the change of mind and disposition.

The gentle, playful Jersey calf, for instance, in taking on the ponderous form of adult life undergoes a change of mind and heart as well. $\mathrm{He}$ 


\section{Male and Female.}

becomes fierce and determined, delights in expending his masculine activity in frightful encounters with his rivals, and at all times is easily excited to irascibility. The cow, on the other hand, gives up youthful sportiveness, does not as a rule show an active desire to engage in combat, unless her calf is in jeopardy, when she will valiantly defend it. Instead of growing more active, she grows less active.

As a result of physical changes in the vocal organs the voice also changes at maturity.

The senseless baa of the calf becomes the sonorous low of the cow, or the harsh and terrifying bellow of the bull.

All through the mammalian life corresponding changes are more or less evident. Young lions are pretty and innocent pets, playful, and as a rule good-natured, - like all babies. The two sexes closely resemble each other, neither having the characteristics which mark the adult forms. At reproductive maturity, there emerges from the universal babyhood, on the one hand the feminine, slender, more docile female; on the other the distinctly masculine, powerful male with his imposing mane, - his helpless baby cry grown into a roar that strikes terror to the heart.

In our familiar friend, the domestic cat, the change is not so much in form as in disposition, the male evincing greater restlessness and pugnacity.

The dog at this period loses his puppy voice, 


\section{76}

\section{Life and Love.}

that infantile falsetto being changed to a manly bass. He also grows quarrelsome, and shows an inclination to demolish strange dogs. As a puppy he is friendly, and shows littie discrimination in persons, liking every dog that does not offer to bite him, and delighted with the caress of any human being.

Later, he is less general in his friendships. He discriminates, and offers to fight certain dogs, discarding all overtures of peace; he becomes highly individualized, has distinct likes and dislikes for people, and develops the feeling of obligation which makes him guard his master's property. If he comes of hunting-stock he expresses more definitely his desire to hunt, and the method of hunting he is best able to employ.

From a puppy like all other puppies, he becomes a distinct individual.

As a rule, the male is most profoundly affected by maturity, and everywhere shows the greatest amount of change.

As the individuality increases, the power to change diminishes.

During his unformed puppy stage the dog learns easily, and then can be trained to many habits useful or pleasing to man. Later, the power to change lcssens, that is, the growing power is in abeyance, the idcas and habits have become fixed, the direction of the individuality is determined, and it then is more difficult for him to learn new ways. 
Through all the higher life individuality becomes emphasized at the period of reproductive maturity; and the higher the life, the more marked is the change.

The power and beauty of adult life are intimately connected with the reproductive faculty. That is the source of the most tremendous stimulus to the mind as well as to the physical life.

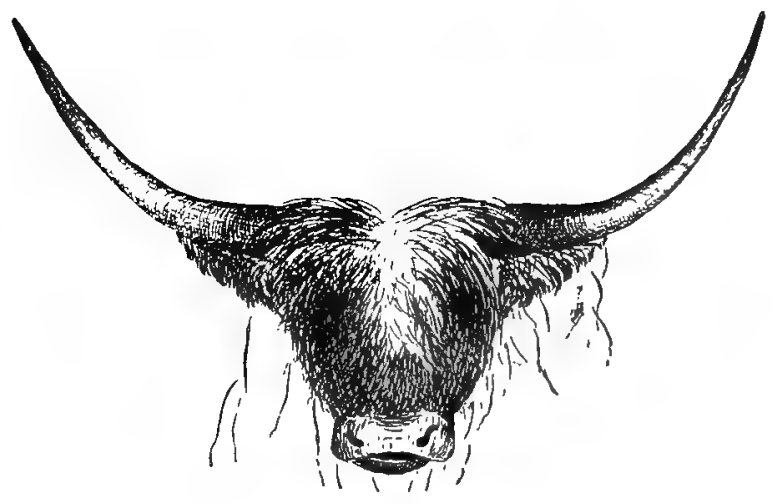


MATURITY.

REFORE maturity the creature has no personal 1 individuality, yet is independent of its race. It lives for itsclf, not for the race.

After maturity the highest personal individuality is achieved, and independence of race lost.

It is no longer free frcm obligation to its race.

It has come into its kingdom, it has found itself, but does not belong to itself.

The reproductive activity, as we have seen, is universal, not only throughout all life, but throughout the individual. Its action is not confined to one tissue or one class of tissucs; directly, or indirectly, it affects all.

Every cell in the female organism responds to the strange feminine impulse sent to it from the tiny cells at the reproductive centre. Infinitesimal in size, these cells, nevertheless, exercise a controlling power over the whole structure. Through their decree femininity sits enthroned, with its many graces.

Every cell in the male yet more vigorously responds to the message of masculinity sent it by the super-active sperm-cells. 


\section{Maturity.}

The female is less profoundly affected by reproductive development, because the life at the generative centres is more calm, n.ore gentle, more conservative; less generative material is produced, and little is lost.

If the reproductive cells, for any reason, fail to develop, the result is interesting. If the ovaries be removed, for instance, there is no characteristic feminine development.

If, from a similar cause, the sperm-cells are prevented from forming, there is no distinctive masculine evolution.

The female, undeterred by the restraining feminine reserve, develops more actively in those tissues most inclined to activity, the skin and its outgrowths, and so approaches more nearly to the male type; while the male, unable to exercise his powerful masculine activity, approaches toward the female type, the two meeting, as it were, on a common neutral plane.

As might be expected, the vigor of the male body is most affected by this loss of reproductive power.

If the sperm-cells are forbidden to form in the first place, there will be no development of masculine characteristics. And even after the full masculine power has been developed the continuing presence of the sperm-cells is necessary to preserve the vigor and masculinity of the creature.

The presence of the fertilizing fluid within the 
male organism acts as a powerful tonic to all the tissues. The muscular power is greater, the courage higher, the individuality more pronounced, because of the influence of this life-giving material.

In order to reduce the restless, determined, and often fierce male animal to a tractable condition, and make him available in performing various labors, man has deprived certain of the lower animals, notably the horse, and bull, of their reproductive power by removing the sperm-sacs. This castration, as the operation is called, is often performed in the infancy of the creature, when, of course, no reproductive material ever matures, and when, as a result, the animal itself never matures. The calf so treated never acquires the attributes of his sex. He can never become the sturdy, stout-horned, powerful-necked, deep-voiced, fiercetempered bull. Instead, he undergoes a general deterioration from the male-type form; his horns refuse to become the sturdy defensive weapons they otherwise would have been, and instead grow long, slender, curving, like those of the cow. His neck will not become so strong and broad, his eye will never glare so fiercely, his voice will develop into a low like that of the cow. His muscles will not become so strong, firm, and elastic. He will attain great size and tend to grow fat. In short, he will become the dull, placid, slow-moving ox, not so strong by one third as he would have been, had he been allowed to develop naturally as a 
beast of burden. He is not so strong, and therefore not so valuable, but on the other hand man considers the loss in strength far more than compensated by the improvement in temper. His disposition, like his big, loose-celled body, is calm. $\mathrm{He}$ does not like to hurry; he is more vegetative than active.

His flesh is not so high-flavored, it is more delicate; and for this reason countless numbers of cattle are forced to undergo the change, the flesh of the bull being strong and unpalatable.

Having lost, as a calf, the power to develop his most noble characteristics, the castrated animal remains an overgrown calf to the end of his days.

American horses are in the same way impelled to gentleness and obedience. With their imperfectly developed bodies they retain their undeveloped dispositions, are mild and manageable in harness, and good servants.

What they gain in servility, they lose in strength, like the ox; they lack the muscular power of the perfect animal.

Deprived of the consuming activity of the sperm-cell, the animal often grows to a great size, becoming correspondingly sluggish and lazy.

Animals thus changed are very likely to grow fat. The perfect male does not as a rule store up much fat. His uneasy, active nature uses up the nutriment as it comes to him. Fat is only reserved food material, and the active creature uses what he 
gets without regard to the future. As all animals tend to take on fat when deprived of their masculine activity, man has not been slow to profit by the fact in raising them for food. The pig, naturally lean and agile, has by man's power of selection and his knowledge of certain laws of life, been reduced to a mass of fat and slothfulness.

In the domestic animals man has taken upon himself the offices of natural and sexual selection; producing, not the forms most advantageous to the creature itself, but those most advantageous to him. He has reduced one animal to a milk-giving machine, another to a fat and meat producing instrument. By protecting and nourishing his useful friends and developing them in directions beneficial to him, he has produced a race of animals wholly dependent upon him for their existence. Should these animals, by some chance, be turned loose to compete with their wild brethren they would quickly be exterminated, any that survived speedily reverting, through their descendants, to the original wild form.

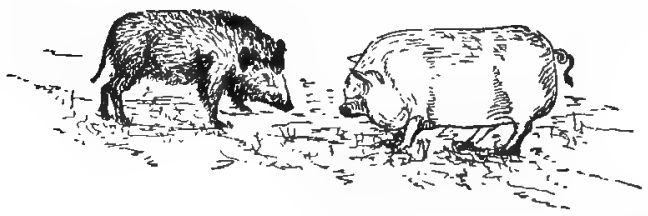

In many cases in the higher life the creature continues to increase in size after the reproductive system has begun to develop. For some time 


\section{Maturity.}

growth and sex development may go on together, the body becoming stronger and richer in all power because of the stimulus it gets from the developing generative centres.

To produce the best results to the forming body this mighty creative force must not be allowed individual expression. Its power must be expended in the general work of strengthening and building up desirable tissue. The time has not come for an expression of its own peculiar power. While growth continues, its work is preparatory, it assists in forming first a fine body, and later, when this important end has been achieved, may perform its own special function to the advantage of future generations.

If the vitality be drawn away from bone and muscle by too early exercise of the reproductive power, the loss can never be made good. The creature will fail to attain the proper size and will also fail in vigor and power.

Parentage is the dowry of the perfect adult life, and its existence in the undeveloped creature entails loss of vigor and all kinds of power, not only upon the parent, but also upon the offspring.

There is not enough power to allow of bodily development and great reproductive use at the same time. One must exist at the expense of the other. After the body gets its perfect growth, there is time enough left for the exercise of that other important function of life. 
Moreover, all through life the vigor and power of the male are maintained by the presence in unwasted abundance of the fertilizing fluid. Any excessive loss of this wonderful stimulus always results in the deterioration, mentally and physically, of the creature. Its power is not only to create new forms, but to rejuvenate, to invigorate, to stimulate and inspire the whole organism.

It is the greatest dynamic force of male life, endowing the being with beauty, making it a power, and bestowing upon it an ineffable charm.

This great sex vitality is capable of conversion into other channels, becoming a source of power in various directions. The perfect horse, for instance, in some countries is kept gentle and quiet by work; the sex activity is thus capable of being converted, to an extent, into muscle power.

Instead of being deprived of his sex power and thereby having his strength lessened, the horse has his superabundant activity converted into useful work; and this can be done with any of the higher animals.

Great activity cannot express itself in two directions at once. One activity exists in excess at the expense of other activities.

Active out-of-door exercise, by supplying abundant oxygen, and working off the superfluous energy through the muscular system, tends to prevent too great stimulus of the sex impulse..

In mammalian life the male has risen to as 


\section{Maturity.}

important a position as the female, and it may be that even more regard is paid by man to his development; for it is well understood that here as elsewhere the tendency of the male to vary is greatest, and it is to the development of superior males that man looks for the power to enhance the value of his herds and flocks.

The femalc, being the conservative element, nourishes that which is; the male, being the radical element, gives the impetus to departures from the old type.

It is not surprising to find the male more highly individualized, as a rule, than the female. The great benefaction, individuality, has come to all the higher creatures through that increased power of variation which is a result of sexual generation. Upon both male and female, individuality has been bestowed in abundance, pertaps upon the female more as a result of inheritance, upon the male through immediate power of variation. It must not be supposed, however, that all power individually to vary has been denied the female; this doubtless is not so. She too possesses the inner activity which causes variation, but apparently in less degree than her mate.

Universal in action, coming down through past ages, working on a tremendous scale, the result of sex life is limitless variation in both sexes.

Nature is fearless; she works in great masses without too stern a regard for details. She makes 
a world theoretically divided into two halves, and is by no means careful to complete cach half to the centre line.

She does not produce types; such uniformity is not within her design.

She goes beyond or remains short of the type, and man, like the old Greek sculptor, discerns the ideal, as a beautiful expression of his intellectual creative power.

Nature abhors mathematical accuracy. On a grand scale only is she definite; her units, which compose her great masses, are magnificently indefinite.

Her males often balance far over toward the female type, her females are often developed toward male ideals.

She separates her world of life into male and female, and then with infinite refinement bestows upon each some attribute of the other. None can claim for his half a monopoly of any one quality.

In the lower life this shifting of the line of sex characteristics has produced some strange results, certain males habitually assuming distinctly feminine functions, and vice versa.

The lower life, with its unreasoning faith in the wisdom of Nature, however, is not disturbed by these anomalies.

Individuality is allowed, and whoever has the power has the right. The opinion of one creature 
concerning the duty of another does not retard the operation of the primal forces.

Individual variability is a very difficult subject to investigate, the forces operating to cause results being so varied and often so obscure. For instance, in many cases the male is more teachable than the female. His tendency to change makes it easy for him to accept changes which are forced upon him.

On the other hand, among certain animals, for example the monkey, the females are said to learn more readily than the males, - not because they are more variable than the males, but because they are less so. The monkey being so restless and active, it has sometimes been found quite impossible to chain his attention to the lesson long enough for him to learn it. His more docile partner, on the contrary, will often pay attention, and therefore learn where he cannot be induced to do so.

To all the conclusions drawn from life there are apparent exceptions, the result of conditions too numerous and too obscure to be at once detected. There are certain great underlying laws, however, which, like such laws in other realms of knowledge, are immutable.

They can be relied upon, and afford explanation of what would otherwise be without the pale of understanding.

They are discovered by regarding the whole mass of evidence, and their exceptions are only 
apparent, - when understood going to strengthen the law they seem to refute.

One of these laws governs the two sexes, keeping them true to their ideal, no matter how much apparent variation may be discernible.

To speak figuratively, the female is the great centripetal force of life. It may be said that she insures permanence, attracts as to a centre, draws to herself and within herself, and prevents scattering and chaos.

That she is to life what gravitation is to matter.

The male, to continue the figure, is life's centrifugal force. He prevents all from gravitating to one point and there coming to rest. He compels repulsion from the centre.

The female, it may be said, keeps life stable; the male keeps it from stagnation. Her stability carried to excess would result in complete rest, which is death; his instability, in complete unrest, which is chaos.

Together they keep an even balance.

Opposite forces, they are of equal necessity, equal value. Either without the other would perish physically; may we not say the same of them mentally and morally, and that they are the two halves, always seeking to become perfect, each through union with the other? 


\section{XXI.}

HUMAN LIFE.

T IFE has swept upward to man. Beginning with the simplest and lowliest of creatures, away back when the earth was just becoming able to nourish the new life forming upon it, there have slowly come forward more and more complex creatures, until at last man himself has been ushered upon the scene.

Not in haste or unheralded did he come forth. No new organs and no new functions came into existence when he came. He was but the climax, the crown of the life that had been for countless ages evolving upon the earth.

Looking back along the tortuous and yet ever ascending pathway life has traversed to its destination in the human form, we reverently discern that Nature, with supreme foresight, recognized man's necessities in the first cell of protoplasm that formed upon the earth. These primitive cells, delicate, perishable in their rude and violent surroundings, yet persisting and multiplying, held within their frail substance the mighty life-force which was later to surge over the globe in countless forms of amazing complexity. 
There was enough foresight in the creation of the primitive cell to include all the coming ages of

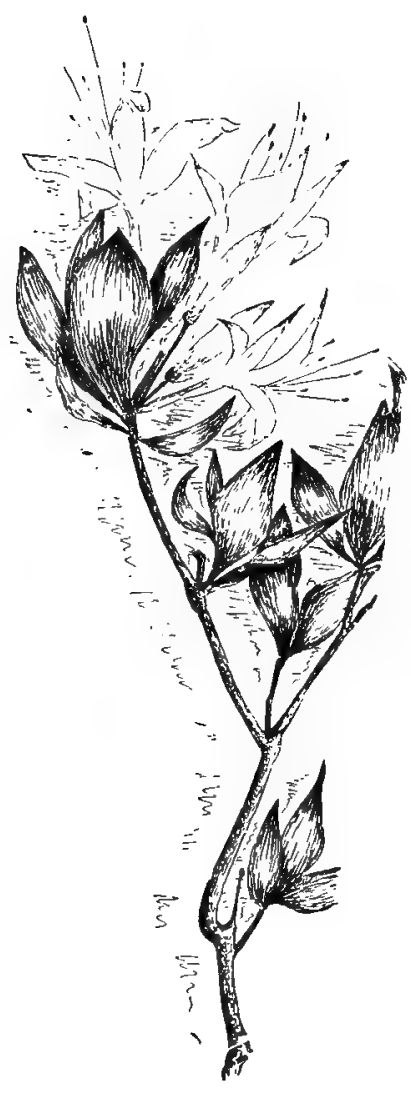
living things, both animal and vegetable. With what amazing economy of design were the innumerable forms of life framed out of the tiny protoplasmic cell, infinite in its mobility, unchangeable in its ultimate structure!

Nor did this sublime economy, this vast unity of conception, stop here. When a complex creature, with distinct organs to perform varied offices, was at length built up from these primal cells, the same prophetic looking to a dim and far future is discernible. An organ having been brought into existence to perform a certain office for one form of life was preserved, modified, a n d adapted to serve various other forms.

For instance, the very lowest forms of life need no digestive apparatus, - the food is digested by 
the body material wherever it touches it; but as the creature became more complex, in course of time there was buiit up a separate apparatus for digestive purposes. At first this was but a simple thing, a tube running through the body of the lowly, worm-like creature, by which food could be received, moistened, made s o l u ble, and drawn into the hungry tissues, the waste being rejected. Such a tube, having developed to serve the needs of the simple creatures whence it originated, is seen to have been retained through form after form of higher existences, growing more complex with glands and convolutions as the necessity for greater nu-

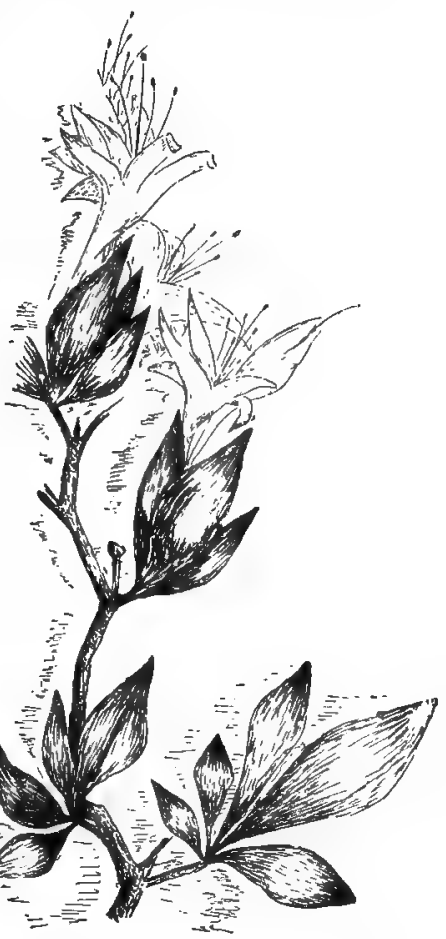
trition increased, but never quite losing its primitive form, and through all life, including that of man, remaining but a tube for the transformation of crude food materials into soluble matter grateful to the hungry tissues. 
The digestive apparatus courses alike through the worm, the serpent, the frog, the lizard, the bird, the four-footed mammal, the man. Nature, having cunningly made a digestive tube to fit her worm, and having made it a cosmic thing capable of infinite expansion as life grew more complex, met the greater needs by simply lengthening and coiling the primitive tube, indenting it with glands that also increased in size and complexity as necessity demanded. Thus was the simple straight tube of the lower animal type developed and elaborated to do duty for even man himself.

And what happened with the digestive apparatus was repeated in all the other structures. Cleverly there was evolved a universal plan of blood circulation, so that modifications of the original type sufficed for all succeeding forms. The nervous system, too, grew in the same way, one startingpoint being common to all animals, simple and complex, the higher animals but showing a greater complexity of the original form.

Organs came into being magnificently plastic. Upon this power of mobility in growing things depended all progress, plasticity being the most essential endowment of life, giving that inestimable power to change, to rise, to depart from the original form, which has resulted in the present condition of life on the earth.

Plastic, full of possibilities of form and function, the various organs arose, and, modified in innu. 


\section{Human Life.}

merable directions, were handed on and on, serving not only the one form whence they originated, but innumerable succeeding and advancing forms as well.

Slowly, yet surely, the admirable support of the backbone came into existence. Once evolved it was not rejected for some other method of support, but, able to serve a multitude of forms, it lent its aid to swimming, flying, creeping, jumping, running, walking creatures in vast profusion. In man it has the essential characteristics possessed by it in all other mammals. And so we see life one beautiful whole, united by the strongest and deepest ties of structure and function. And when we approach the most important physical fact of all life, the fact of reproduction, we find it too but one great cosmic truth, working alike from lowest to highest, increasing in complexity as the life ascends, until it culminates in the life of the higher mammals. And here, too, in his physical life, man shows his kinship to all other life. What is true of the reproductive phenomena of the higher mammals is true in every particular of him as well. Sperm and egg-cell work out the human destiny as they do that of lower life-forms. Human life, like all other life, stands upon a physical superstructure. To behold the marvels of his own form, man needs but look out into the world of life about him and see there the reflection of himself. His physical needs are the same as those of his humbler neigh- 
bors, his hunger as imperative as theirs, his body nourished as theirs are. He, too, needs air, light, and warmth, and without them must die. He, too, must reproduce in offspring his physical form that his race may not become extinct.

Not only in physical phenomena, however, do we find man united to all other life. As his body is an unfolding of the possibilities of protoplasm, that strange basis of all living forms, so are his intellectual and moral faculties an unfolding of certain possibilities discernible in the lower life.

Not a single power resides in man whose roots cannot be traced down into that great world of life of which he is the fair blossom.

In one particular only does man differ essentially from the lower life. To him has come a transcendent development of those nerve centres by means of which he is enabled to comprehend the world about him. The body, which encloses and circumscribes the living creature like a wall, keeping it distinct from the world without, in man offers less obstruction to the flowing in of the universe. In him the channels of communication with the outer world are freer. To a degree unique in living beings, he can comprehend the world in which he lives. Not because of superior physical powers is this so, however, for the lower animals excel him in many directions; the dog can smell better, the eagle can see farther, the deer can run faster, the lion can outdo him in muscular strength; yet he has a 
power that gives him dominion over all of these. By this power he can outstrip the swiftest flight of the deer, and fly above the highest soaring of the eagle. And this power resides not in his body, but in the marvellous activity we call his mind.

That it is which frees him to an extent from the fetters cast upon him by the limitations of the body. And, his intellect having reached a development far beyond that of any other creature, we find life in the human being reaching out in new directions. The purely physical desires cease to be all-powerful, - the body is under the control of the mind; instead of being governed by external and accidental circumstances, it is to a new and marvellous extent subject to the intellect.

By this powerfully developed mental function has the human race been separated from all other life.

Man ceases to be only an animal, he becomes something more; he becomes a mind with a physical body as an organ of expression, instead of being a body with a dawning mind.

With the development of the mind the vital functions are also put upon a different plane. Hunger is no longer a mere animal craving for food, to be appeased at the first opportunity of satisfying it. It is subordinate to laws of various kinds, - not nature's laws any longer, but mind's laws. The higher type of man will starve rather 
than violate these human laws. He will not eat the first food he comes to because he is hungry; he will not eat that which belongs to another, even though he starve.

Hunger, too, has been beautified, so to speak-there is a certain asthetic feeling connected with it which has made its gratification a social event and surrounded it with beautiful objects.

And so his whole physical life has been placed upon a new level in the thought of man. His pleasures become those of the intellect rather than those of the body, and physical gratification of any sort is complicated by the most subtle and powerful mental and emotional phenomena.

Love is lifted to a new plane, invested with a new meaning. As life dawned in the single cell, so did love dawn in the protozoön. As life grew more complex, so did love outgrow its first primitive condition of simple cell-attraction and clothe itself with increasing powers. Upward it struggled, breaking out in prophetic flashes of beauty in the lower forms of life.

Upward struggled life, creating few new organs, but developing those already existing. And upward struggled love, sparingly creating new expressions, but infinitely enlarging those powers already feebly acting.

Both life and love in the sun of human intelligence blossomed in beauty, and man passed upward to a plane not reached by other life-forms. For 


\section{Human Life.}

with conscious intelligence came the higher development of the moral nature.

Man, through knowledge, became a responsible agent; no longer wholly the creature of circumstance, he began to rule his own destiny and determine his own line of progression. With knowledge came to him the sacred responsibility to live in obedience to the laws he had discovered. The result of obedience was the privilege of mounting with conscious joy the heights still before him; while disobedience brought the terrible punishment of conscious retrogression. 
198

Life and Love.

\section{XXII.}

MAN AND THE COMMUNITY.

Fuman life presents its greatest difficulties to 1 our understanding, because it is not the life

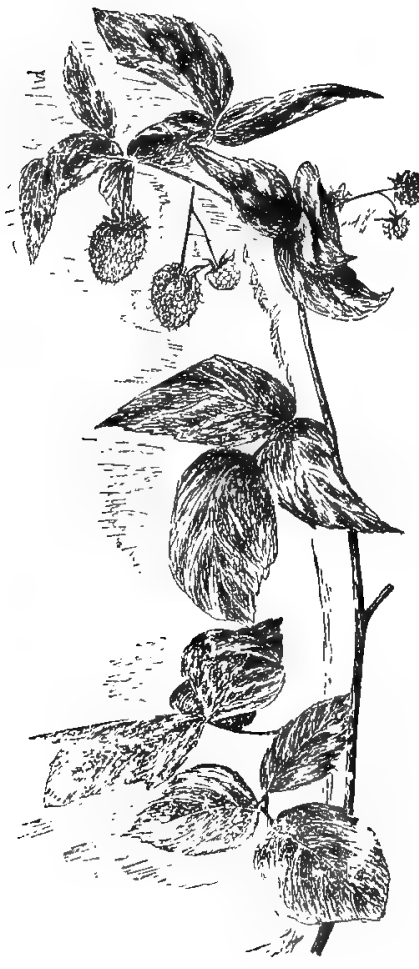
of the individual alone, but the life of society, which must be considered. In most of the lower animals the controlling causes are few and simple, and directly referable to the creature's surroundings in Nature.

In civilized man the Nature surroundings play a very subordinate part. $\mathrm{He}$ controls Nature instead of being controlled by her; therefore it is not Nature's influence on man, but the far more complex condition of man's influence on mail which has to be studied. In other words, it is the influence of mind instead 
of Nature upon man which most powerfully affects human development. The higher and more complex the civilization, the more entirely is it under intellectual, rather than Nature control, - by $\mathrm{Na}$ ture control being here meant the influences exerted by food, climate, and all the causes affecting natural selection among the lower animals.

One of the most marked characteristics of civilized man is the high development of the altruistic sentiment, the care for others instead of the care for self. In the lower life the creature is, as a rule, more selfish, more egoistic, is more apt to think first and only of self-preservation, self-comfort, selfgratification. Exceptions to this rule are found in the case of certain insects, which live in communities and which show an individual subordination to the good of the community very like that seen in human life; and among the females of those animals that rear their young; very rarely among the males, excepting, in part, in the division of birds.

Altruism in its scientific sense might almost be used as a synonym for civilization, and nowhere is the effect of altruism more noticeable than in the sex-life.

There is a certain harsh line of division between the sexes in the lower life which is softened and lessened in the human. The influence of the altruistic feelings, which in the human being have so wonderfully and uniquely developed, has operated to a certain extent to obliterate those sex-charac- 
teristics which affect the conduct of the individual, and which, helpful to the preservation of the species in the lower life, are opposed to the growth of the higher nature of man.

The effects of this altruistic growth are evident at a glance in the life of the community as a whole. In the lower life, and in savages, the community in its characteristics approaches the masculine type; it is selfish (egoistic), unstable, variable. The herd of buffalo, for illustration, roams about in search of food and water, charging relentlessly and destroying whatever enemy comes in its way. The savage tribe often has no fixed abode, but roams about from place to place; where it has a home it is, as a rule, given to frequent war with its neighbors, and is liable to be uprooted by a stronger foe and absorbed and thus lost, or it may be destroyed, or compelled to move on. While this is true of the savage community as a whole, that is, considered as a nation, a unit, in its internal organization, on the other hand, it is essentially fominime in its characteristics; its habits are simple, stable, not liable to change. It makes no inventions, elaborates no complex machinery.

To make clear what is meant, let us compare the savage community to a ball which is tossed and rolled about here and there. The particles within the ball, which compose its substance, however, do not change in relation to one another. The ball as a whole may be considered unstable, masculine in its tendencies; its constituents stable, feminine. 


\section{Man and the Community.}

Civilized life, on the other hand, presents the opposite of these conditions. The community as a whole is constantly tending away from the masculine toward the feminine type. It is stable, invariable; it does not change its location, it does not seek war with its neighbors. It is quiescent, law-abiding, altruistic in a high degree. It builds asylums for its unfortunate members, and rejoices in the progress and welfare of other nations. In its internal life, on the contrary, it has moved away from the feminine type toward the masculine. Here is seen an expression of the greatest variability. Domestic and commercial life within the nation grow complex, unstable. New inventions are constantly changing the order of things. The fiercest competition, the strongest egoism exists.

To continue the illustration used in the case of the savage community, let us suppose the ball rolled about from place to place to have been a seed which now takes root and grows. The plant is fixed as to its outer conditions, it represents the civilized community, but internally, its cells are all active, all highly individualized and developing in various ways.

None can question that the elements composing civilized society are developing the highest possible individuality.

In the beginning the protoplasm lived, formless, simple, sacrificing nothing to race ends.

But this condition was incompatible with prog- 
ress. Protoplasm passed on to another and higher state, where it assumed definite form, and in consequence of taking upon itself this form both perished and progressed. Its form fell away in time; it was said to die. In the higher and complex forms of life the individual was temporarily submerged that the race as a whole might advance. This individual submergence was only apparent, however, it being but a necessary step to the development of a higher and more complete individuality.

The changes in the attitude of the community as a whole, and in the internal life of the community are but the working out of the law of progress on a higher plane, and are fraught with the gravest significance. Examined closely they will be seen to contain the conditions of man's progress, that is, the conditions for the expression of the highest degree of individuality.

In approaching toward the feminine type the community as a whole is seen to have freed itself from the more extreme expression of the masculine characteristics only, - it has become modified, its sharp angles rounded.

Courage remains, desire to fight for the sake of fighting goes. Energy finds expression in other and nobler directions. Thus the community, in acquiring certain of the feminine characteristics, as altruism and stability, does not discard all of the masculine characteristics. On the contrary, 


\section{Man and the Community.}

there is a union of both, the highest masculine and highest feminine characteristics being retained, while the lower of both are discarded.

The result is a nation, strong, fearless, self-sustaining, yet calm, temperate, stable, considerate of others.

In the internal life of the nation the change which has taken place is analogous to that in the nation as a whole.

The general tendency has been away from the stable, unchanging, simple altruistic domestic life, toward a highly complex, ever changing, egoistic social life, where the struggle for existence in the higher sense is at its fiercest. The struggle for existence has passed from the species to the individual. The life of the species is secured by the conditions arising from the altruistic, stable community; the physical life of a sufficient number of individuals to preserve the species is assured. The struggle is now between the individuals comprised in the community, for the higher prizes of human existence.

The struggle is not now so much one for mere privilege to live as it is a struggle for prestige, for wealth and power, and opportunity to develop the higher faculties.

In other words, the question is no longer one of mere physical strength or adaptability, but one of intellectual power.

In the production of man physical evolution 
seems to have reached its climax. Progress upward now appears to be no longer of the body; in man physical evolution stops, the highest seems to have been reached. Progress has passed on from physical expression into a new field; it has become the development of intelligence.

Certain changes which mark the advanced community as a whole, necessarily and in no less degree mark the individuals composing it. The sexes are not sharply distinguished from each other in the intellectual and emotional realms. On the whole, men as a class probably show a preponderance of what may be termed masculine characteristics, as greater egoism, variability, activity; but these masculine characteristics have been modified, lessened, effininized, so to speak. In the higher type of man the best and highest fominine characteristics have been fused with the best and highest masculine characteristics. The fighting instinct, for instance, has become moral courage; the tendency to vary expresses itself in great intellectual development; instability and restlessness have become intellectual rather than physical qualities, leading to notable inventions and discoveries.

Brave and gentle, strong and tender, inventive and patient, the finest type of man owes his superiority to the transforming and illuminating power of his inheritance of womanly qualities.

And while, in the dawning light of intelligence, woman has thus elevated her mate, he has equally 


\section{Man and the Community.}

transformed and illuminated her life. Women as a class doubtless show a preponderance of what may be termed feminine characteristics, as greater altruism, stability, less power of variability, but these feminine characteristics are everywhere modified by the action of masculine characteristics.

In the higher type of woman the best and highest masculine characteristics have been fused with the best and highest development of the feminine characteristics. Altruism, for instance, has been rationalized and guarded by the exercise of greater reasoning power; stability or inertia has been lessened and prevented from forming an insurmountable barrier to progress. The tendency to vary has been strengthened; the more negative nature has progressed to a more positive condition. Courage, inventiveness, and greater strength of intellectual perception have been fostered in civilized woman. Her submission to man gradually lessens before the upward progress of her mind. She places herself as his equal, - as the other half, without which his half-life cannot be complete.

Although less inventive than man, she still invents. Genius, that crown of the power of variability, is not denied to her.

In the internal, individual struggle for the higher existence woman develops such masculine characteristics as enhance her power and her attractiveness. Retaining the highest and best of her feminine qualities, she fuses with them the highest 
and best of the masculine qualities, until the highest type of woman, gentle and brave, tender and strong, patient and inventive, is born to bless the world.

Nor does this borrowing of the characteristics of each by the other mean the merging of the two sexes into one, - the obliteration of sex difference and hence of sex attraction. It means the elevation of man by developing his masculine qualities in the direction of their highest possibilities, and by adding to manhood a new charm, a subtle grace, an irresistible beauty. It means the elevation of woman by the development of her womanly qualities in the direction of their highest possibilities, and by adding to womanhood a new power, a deeper, more far-reaching sympathy, an ineffable glow, and a nobler beauty.

The mind is a mighty solvent; through it the two sexes have been united in an intellectual union, from which has been born a new man, with the dominant masculine characteristics developed in their noblest direction, and enriched by union with feminine characteristics; and a new woman, with the feminine characteristics grandly developed and enhanced by what was once in the province of masculine knowledge and activity.

Thus is the sympathy between the two sexes stronger and on a higher plane than could otherwise be possible. The attraction of the one to the other is more subtle and more wrought about by noble and worthy sentiments. 
The highest type of human love is a result of this unique development of man and woman. To borrow a figure, human love has emerged from its chrysalis state; it has become the beautiful imago.

In the early pages of this book it was said that love was almost as great a mystery as life. Love, too, is a physiological fact, universal in its operation, wonderful in its development, mighty in its consequences. But in man, and we know not how much below him, it is more than a physiological fact.

Love glorifies human life, it transforms the nature, enlarges the sympathies, is the source of the mightiest inspirations.

In the glow of this divine passion the lover sees in his beloved the centre of all beauty, all good.

His own nature softens, widens, deepens. In her presence he has visions of greatness, of immortality.

Egoism gives way to a sublime altruism; he is ready to give all for his beloved. Nor is this the end; the new and powerful emotions which assail him overflow on all sides, - he has developed a sympathy with the whole human race. Love grows so luxuriantly and blossoms so divinely that it embraces human life and all Nature. Man sees new and unsuspected beauties in the world about him; he feels a strong impulse to new endeavors; he is lifted into a region of inspiration whence he often 
creates astonishing and beautiful images to delight his fellow-man.

Endeavoring to give expression to the visions which fill his imagination, he creates pictures, statues, poems, melodies, which delight and inspire and console his fellows.

Love glorifies mind and heart and spirit. It chastens the lower or mere physical impulses, it strips man of his clinging inheritances from the less exalted earth-life.

From the first, life as a whole has tended upward; up, up, it has moved, through cycle after cycle of advancing forms to man. And in man it has moved from the lower savage to the Plato, the Shakespeare, the Emerson. And up it will continue to move, the whole race rising toward the plane of the most highly developed individuals.

Love has been the great power in the later world-progress, - love, reaching out to that sublime consummation, love of all humanity.

The survival of the fittest is not, in man, the survival of the one endowed with the greatest brute force or the greatest selfishness. The teachers of men, those whose lives and works live and influence the race are those with the finest intelligence, the grandest spiritual growth.

If in his search after happiness and knowledge, in his groping for the best good this world can offer, man falls below his best; if he mistakes the high meaning of love and its offices; if he attempts 
to snatch pleasure from the lower rather than the higher sources, - he lives a life of internal conflict, without peace and without happiness. Too late he learns that only through the higher conception of love can life be crowned; that he has missed the great prize which would have reconciled him to the universal, and constituted him one of those in the van of the upward and onward march of that Great Progress which is inherent in Life.

Divorced from the higher human love, the finest and grandest possession of the sons of men, he looks back at a life wasted in the pursuit of pleasures which turned to pain and lamentation in his grasp. Man is ever striving, though it may be unconsciously, to conceive of and to attain that high and perfect love which shall reconcile him to life and to the universe.

Even in failure, even when pursuing a false ideal, there glimmers before him the saving and alluring light of the true love. And so struggling on, sometimes winning, sometimes failing, but always striving and yearning, the race of man goes upward. In time the efforts of these half-seeing, yet ever longing souls pierce through the clouds, and the sun streams with quickening radiance upon the whole mass of humanity.

Thus does the experience of the individual become the knowledge of the race. 


\section{XXIII.}

\section{CONCLUSION.}

J is the province of science to investigate, to 1 demonstrate, and to declare what are facts, and not only to say what is, but also to declare what has been. Thus are the vast periods of the world unfolded, and thus the past history of life upon the earth.

Many beholding the methods of science are seized with a fear that in the pursuit of the exact truth about our physical world some higher and more important truth will be neglected, or that we must inevitably lose sight of that something which is back of and is the cause of all physical manifestations. But so far is it from true that the facts of the physical world are rendering secondary or less important the facts of the inner consciousness, it has rendered them more absolutely necessary to our thought. To draw a line of distinction, one would say that the rise of that great method we call the scientific - that by which we determine facts - has so enlarged and ennobled the great domain of the intellect which we call the philosophic that we can hardly tell where it begins or 
where it ends, - just as, looking back through the ages and seeing two great men standing side by side we can hardly tell, when we say Aristotle, whether we speak of the intellectual kingdom of science, or whether we speak of philosophy when we say Plato.

But one thing we feel certain of, - that our century has had a method, has made discoveries, has achieved exact results, by which philosophy has become almost a science of certainty. And so far have we advanced that when we look at life in all its manifestations we instinctively feel that life is a manifestation of a power, a force, a spirit which constitutes its glory.

What Plato and Socrates called psyche has now become to us our commonest philosophic thought. We think of ourselves as psychological beings. We do not come by our souls through any dogma of religion, but as the highest philosophy man has had in the world.

We can now look about us and see that, in all races and indeed in all historic times, man has been conscious of having a soul. The thought of this Psyche, this Soul, this Inner Mind, related as it must be to the whole of that power which is the spring of all being, fills us with hope, raises us up to great conceptions, great pleasures, and great pains. As love is the hope of our race, so the soul is the conscious master of it.

Multitudes now rising higher and higher in the 
conceptions of beauty and of greatness feel that the next great step is being taken when we shall become conscious citizens of an imperishable universe, instead of trembling denizens of a perishable world.

Many are seized with a growing hope that not only we of the upper ranks have this inner life, but that all nature shares it, and that love is its expression and its method.

In this conception is escape from materialism, that threat of the ignorant and unbelieving.

That man is psychically related to all life is the belief of millions in the Eastern world, and the hope of millions in our Western world.

That man, the crown of the earth life, is advancing toward the highest expression of individuality, and that individuality is the ultimate goal of progress, are the great truths that have been made manifest to the Western civilization, - truths that will make it the final conqueror of all civilizations.

That Nature is essentially and primarily material has not bcen proven. It is man's latest achievement to conceive that all existence is a unit; that all life, all law, all love is divine; all has some sort of development of soul. So, instead of escaping from Nature, of setting himself apart as something essentially different, man, looking calmly about him, recognizing himsclf as a part of Nature, includes her in the universal scheme of development. Instcad of isolating himself, he conceives 


\section{Conclusion.}

that those other expressions of life may share with him in the divine love and progress. Man having risen to a state of at least partial knowledge, perceives that the whole of being is full of desire, of aspiration, of love.

When he can rid himself of his materialism, in part a remnant of the mistaken conceptions of an ancient people; of his dogmas founded on a mistaken tradition long since contradicted by science; when he can believe that love is in and of the soul, will he not pull the world speedily. out of its baser ideas, and up into its higher beauties and uses?

In that wonderful " Story of my Heart," Richard Jeffries gives us this conception of man's soul:"By the word soul, or psyche, I mean that inner consciousness which aspires."

Again he says, "I consider that the highest purpose of study is the education of the soul, or psyche."

And again, "Beyond and over the horizon I feel that there are other waves of ideas unknown to me, flowing as the stream of ocean flows."

"Let me launch forth and sail over the rim of the sea yonder; and when another rim rises, over that, and again and onwards."

Let us add to these words, for the inspiration of those whose thoughts wander beyond the limits of daily occupation into the regions of immensity which lie so near the door of our feeble senses, this thought from one of France's greatest minds:- 
"Push the Infinite as far as you can. Do not fear, you can always push it farther."

Every day to some minds of our race new reaches of thought open, seemingly infinite.

"Shall any gazer see with mortal eyes?

Or any searcher know by mortal mind? Veil after veil will lift, but there must be

Veil after veil behind."

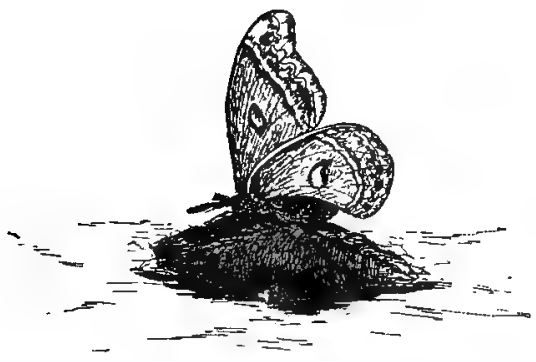




\section{THE BEE PEOPLE}

BY

Margaret Warner Morley

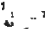

$+\frac{1}{4}+x^{2}$

I?

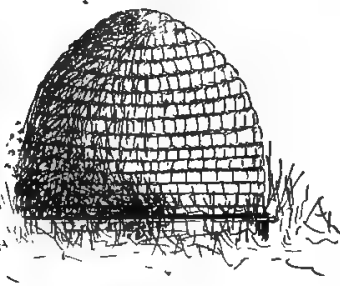

ILLUSTRATED

$I 2 \mathrm{mo}$

PRICE, \$1.25

Nothing could be more cinarming, both as regards matter and manner, than "The Bee People." The story is for little folks, but is so full of information, and so scientifically and artistically illustrated that it must become everybody's book about bees. . . . Next to the discovery of the facts for one's self is the de. lightful surprise that meets one on almost every page of the volume. - Cbicago Tribune.

The author writes in a graceful, simple style, and she has such a happy faculty of combining instruction with entertainment that the young reader of this book will gain practical knowledge about bees and flowers while enjoying what seems to be a fascinating story book. Numerous illustrations add to the attractiveness of the text. - The Boston Globe.

For sale by bookseller's generally, or will be sent, postpaid, on receipt of the price, by

\section{A. C. MC̣CLURG \& CO., Publishers}




\section{A SONG OF LIFE.}

By MARGaReT WARNER MORLEY. With profuse illus. trations by the Author and by Robert Forsyth. Price, $\$ 1.25$.

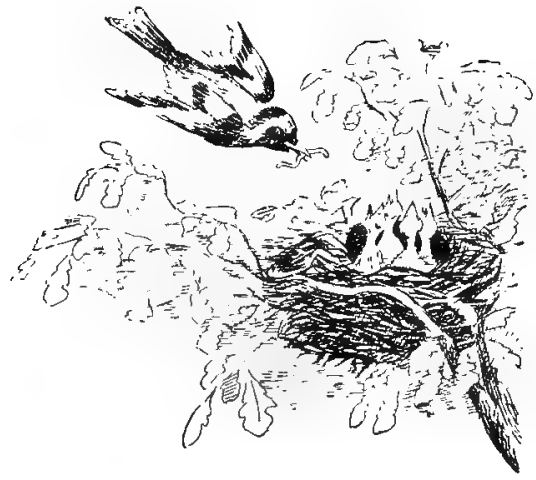

A most charmingly instructive book; and so beautifully explained is the great subject of life that the little ones for whom it is intended cannot but receive great benefit, while the older ones will also learn mich. Something of flower life, something of fish life, of frogs and of birds, and a chapter on human life, form the subjects of this book, all told in the graceful manner of a womanly woman whose love for Nature has given her a keener insight into Nature's secrets and a greater ability to impart those secrets to others with the ease of face-to-face talks than is vouchsafed to many people. - Boston Times.

For sale by booksellers generally, or will be sent, postfaid, on receipt of the price, by

A. C. McCLURG AND CO., Publisbers, CHICAGO. 







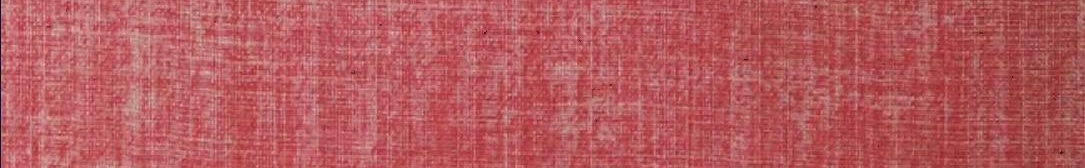

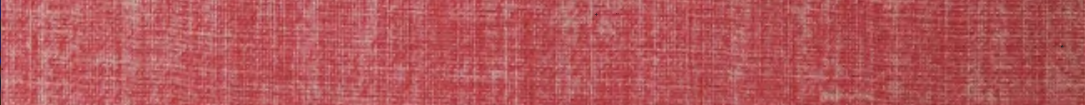

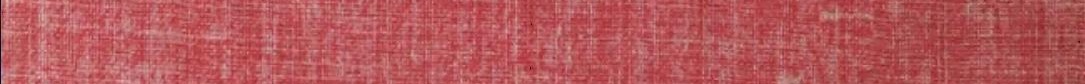

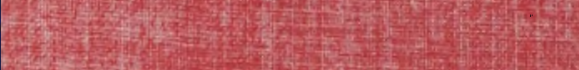
(2) A

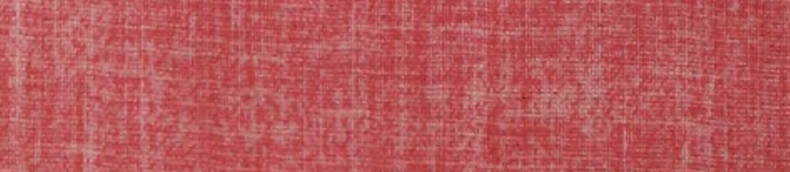

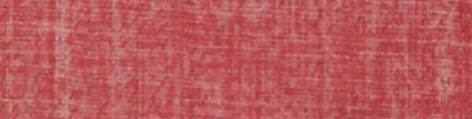

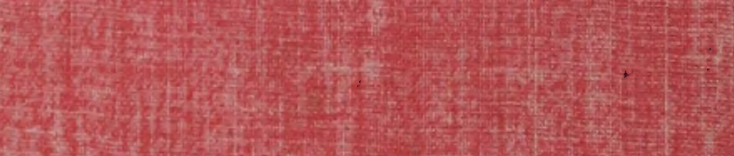

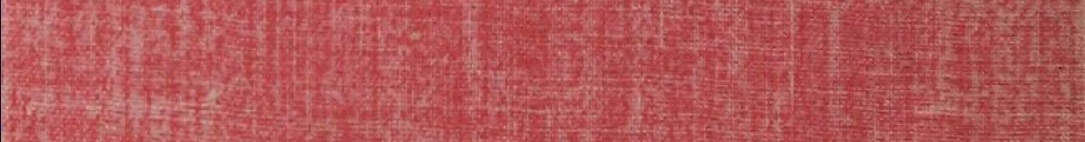

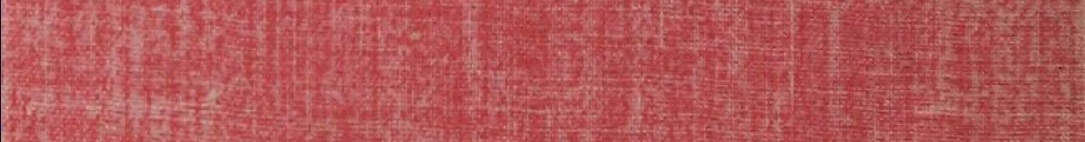

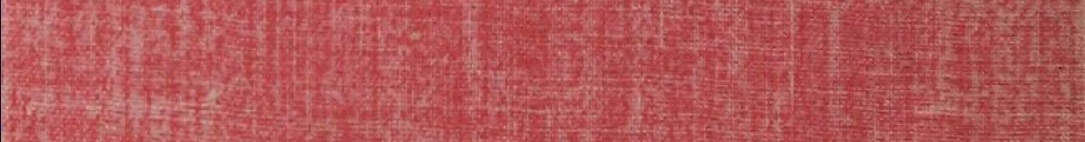

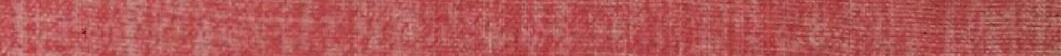

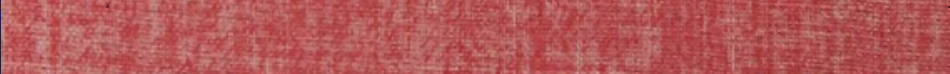

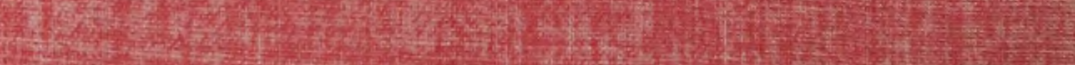

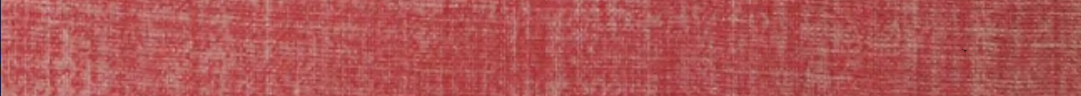

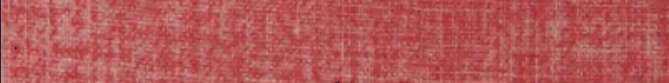
30
3
3

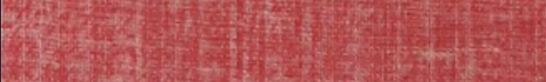

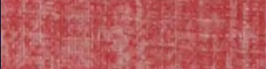

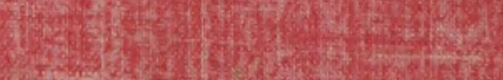

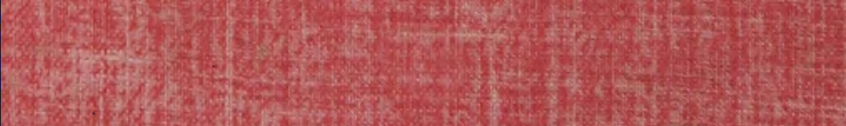

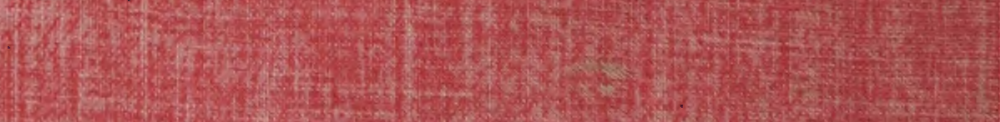

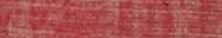

H. 